San Jose State University

SJSU ScholarWorks

Master's Theses

Master's Theses and Graduate Research

1994

\title{
Characteristics of slope failures in a portion of the Santa Clara Formation, Saratoga Foothills, Santa Clara County, California
}

Brian David Reddig

San Jose State University

Follow this and additional works at: https://scholarworks.sjsu.edu/etd_theses

\section{Recommended Citation}

Reddig, Brian David, "Characteristics of slope failures in a portion of the Santa Clara Formation, Saratoga Foothills, Santa Clara County, California" (1994). Master's Theses. 948.

DOI: https://doi.org/10.31979/etd.e6w7-fe73

https://scholarworks.sjsu.edu/etd_theses/948

This Thesis is brought to you for free and open access by the Master's Theses and Graduate Research at SJSU ScholarWorks. It has been accepted for inclusion in Master's Theses by an authorized administrator of SJSU ScholarWorks. For more information, please contact scholarworks@sjsu.edu. 


\section{INFORMATION TO USERS}

This manuscript bas been reproduced from the microfilm master. UMI films the text directly from the original or copy submitted. Thus, some thesis and dissertation copies are in typewriter face, while others may be from any type of computer printer.

The quality of this reproduction is dependent upon the quality of the copy submitted. Broken or indistinct print, colored or poor quality illustrations and photographs, print bleedthrough, substandard margins, and improper alignment can adversely affect reproduction.

In the unlikely event that the author did not send UMI a complete manuscript and there are missing pages, these will be noted. Also, if unautborized copyright material had to be removed, a note will indicate the deletion.

Oversize materials (e.g., maps, drawings, charts) are reproduced by sectioning the original, beginning at the upper left-hand corner and continuing from left to right in equal sections with small overlaps. Each original is also photographed in one exposure and is included in reduced form at the back of the book.

Photographs included in the original manuscript have been reproduced xerographically in this copy. Higher quality $6^{n} \times 9^{n}$ black and white photographic prints are available for any photographs or illustrations appearing in this copy for an additional charge. Contact UMI directly to order.

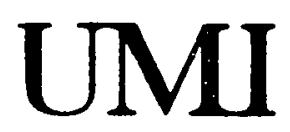

A Bell \& Howell information Company 300 North Zeeb Road. Ann Arbor. MI 48106-1346 USA 313:761-4700 800:521-0600 


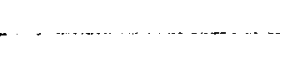


CHARACTERISTICS OF SLOPE FAILURES IN

A PORTION OF THE SANTA CLARA FORMATION, SARATOGA FOOTHILLS, SANTA CLARA COUNTY, CALIFORNIA

\author{
A Thesis \\ Presented to \\ The Faculty of the Department of Geology \\ San Jose State University
}

In Partial Fulfillment

of the Requirements for the Degree

Master of Science

By

Brian David Reddig

December, 1994 
UMI Number : 1361207

UMI Microform Edition 1361207

Copyright 1995, by UMI Company. All rights reserved.

This microform edition is protected against unauthorized copying under Title 17, United States Code.

\section{UMI}

300 North Zeeb Road

Ann Arbor, MI 48103 
(- 1994

Brian David Reddig

ALL RIGHTS RESERVED 


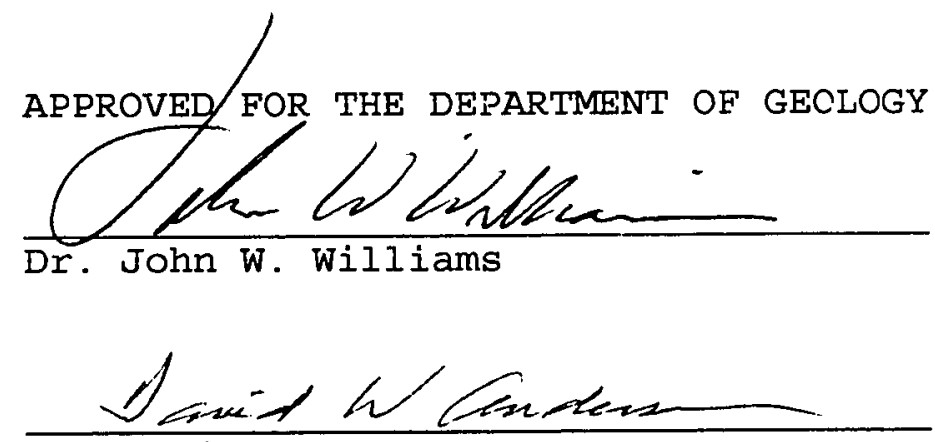

Dr. David $w$. Andersen

Deboral R Mare

Dr. Deborah Harden

APPROVED FOR THE UNIVERSITY

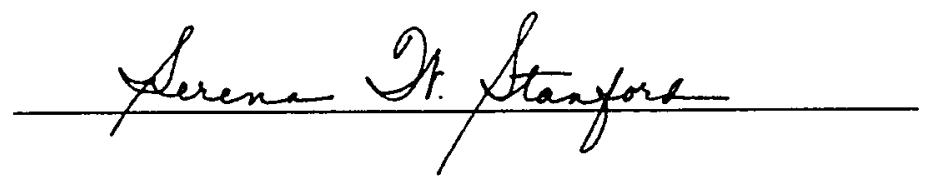




\section{ABSTRACT}

CHARACTERISTICS OF SLOPE FAILURES IN A PORTION OF THE SANTA CLARA FORMATION, SARATOGA FOOTHILLS, SANTA CLARA COUNTY, CALIFORNIA

by Brian D. Reddig

Geology, slope angle, slope aspect, vegetation, geotechnical properties, structure, slope profile, and precipitation were investigated to determine which factors have the greatest impact on slope stability.

Landslides are twice as common on grass-covered slopes compared to forest- and brush-covered slopes. Landslides are twice as common on south-facing slopes compared to northfacing slopes. The disparity in landslide occurrence between the Arastradero and Stevens Creek lithofacies reflects the difference in vegetation distribution, as opposed to lithologic properties. Landslides are more common along mid slopes and are rare on upper slopes.

Samples collected from landslide scarps and failure planes exhibited marked differences in geotechnical properties compared to samples from stable areas.

From 1962 through 1994, in seasons when precipitation totals exceeded $762 \mathrm{~mm}$, landslides occurred in greater numbers than in seasons with lesser rainfall. These landslides tended to form after antecedent precipitation exceeded $250 \mathrm{~mm}$ and storm totals exceeded $150 \mathrm{~mm}$. 


\section{ACKNOWLEDGEMENTS}

I would like to thank Drs. Williams, Andersen, and Harden for their helpful critique, valuable suggestions, and for keeping my study within a workable scope. Special thanks go to Dennis Fox for providing technical assistance, resources, and constant good humor. 


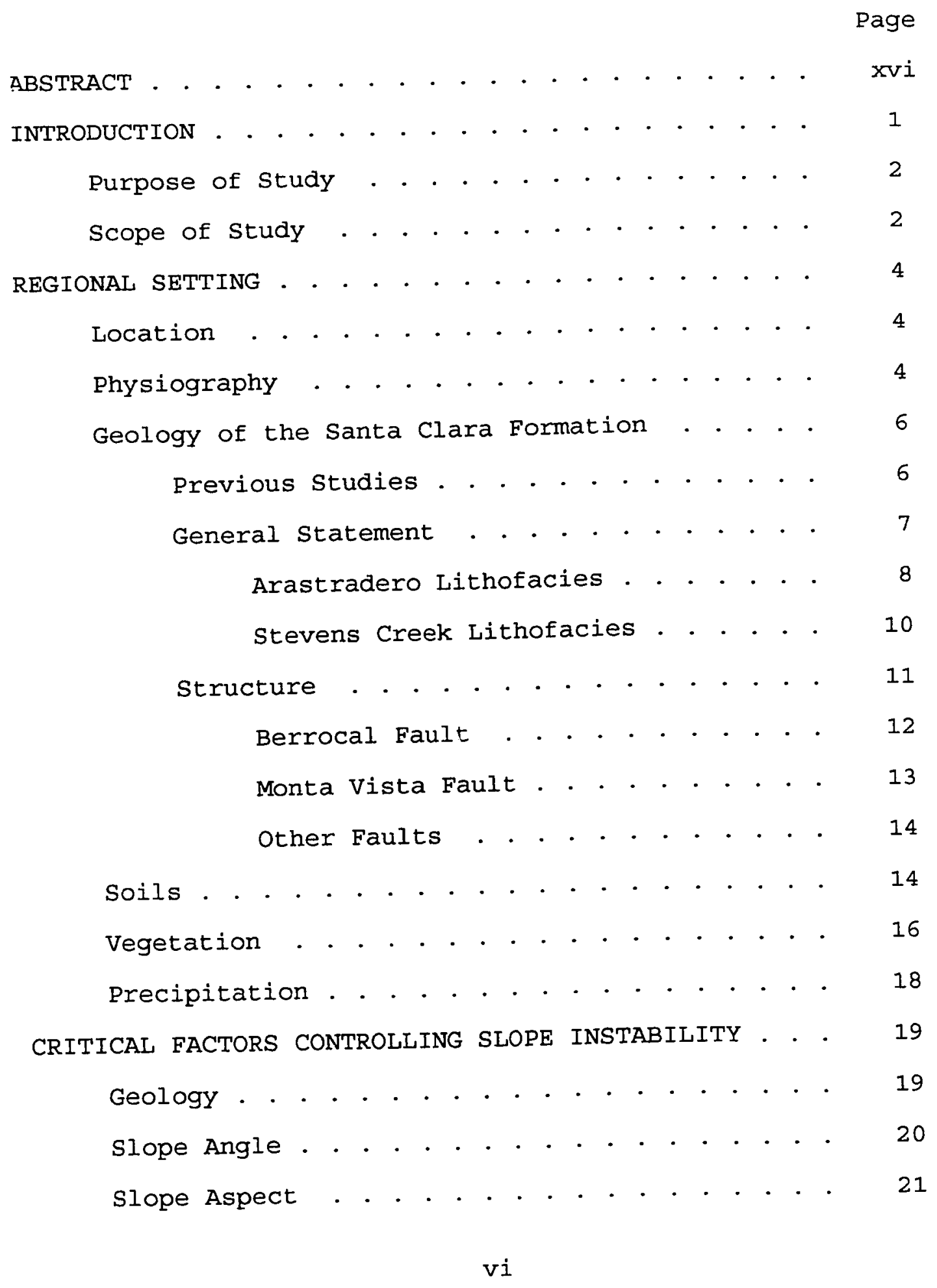


Vegetation . . . . . . . . . . . . . . 21

Geotechnical Properties . . . . . . . . . 22

Structural Relationships . . . . . . . . . 23

Slope Form . . . . . . . . . . . . . . 24

Precipitation . . . . . . . . . . . . . . 25

REGIONAI INVESTIGATION . . . . . . . . . . . . . 27

Data Compilation . . . . . . . . . . . . 27

Computer Database . . . . . . . . . . 27

Landslides . . . . . . . . . . . . 28

Geology . . . . . . . . . . . . . 30

Slope Angle . . . . . . . . . . . . . 31

Slope Aspect . . . . . . . . . . . . 31

Vegetation . . . . . . . . . . 32

Data Manipulation . . . . . . . . . . . 33

Boolean Logic . . . . . . . . . . . . 33

Boolean Grids . . . . . . . . . . 34

Boolean Logical Operations . . . . 34

Boolean Grids of Factors . . . . . . . 35

Example of Evaluation Procedure . . . . 36

Relationships Between Individual Factors and

Landslides . . . . . . . . . . . . . 37

Landslides . . . . . . . . . . . . 37

Geology . . . . . . . . . . . . . 38

Slope Angle . . . . . . . . . . . . . 39

Slope Aspect . . . . . . . . . . . . . . . 43

vegetation . . . . . . . . . . . . . 47

vii 
Interrelationships Between Factors . . . . . 51

Slope Angle and Slope Aspect . . . . . . . 51

Slope Angle and Vegetation . . . . . . . 52

Slope Aspect and Vegetation . . . . . . 56

Interpretation of Results . . . . . . . . . 60

Slope Angle and Landslides . . . . . . . 60

Slope Aspect and Landslides . . . . . . 67

Vegetation and Landslides . . . . . . 70

Geology and Landslides . . . . . . . . 75

Landslide Potential Map . . . . . . . . . . 79

SITE-SPECIFIC INVESTIGATION . . . . . . . . . . . . 84

Geotechnical Properties . . . . . . . . . 84

Data Compilation and Manipulation . . . 84

Results . . . . . . . . . . . . . . 85

Atterberg Limits . . . . . . . . 85

Residual Shear Strength . . . . . . 86

Inplace Dry Density and
Natural Moisture Content . . . . . . 87

Percent Clay Content and Median

Grain Size . . . . . . . . . . . . 89

Clay Mineralogy . . . . . . . . . . 91

Structural Relationships . . . . . . . . . 94

Data Compilation and Manipulation . . . . 94

Results . . . . . . . . . . . . 95

Slope Form . . . . . . . . . . . . . . . 95

Data Compilation and Manipulation . . . 95

Results . . . . . . . . . . . . 97

viii 
Discussion . . . . . . . . . . . . 100

Geotechnical Properties . . . . . . 100

Atterberg Limits . . . . . . . 100

Residual Shear Strength . . . . . 102

Inplace Dry Density and Natural

Moisture Content . . . . . . 103

Percent Clay Content and Median
Grain Size... . . . 106

Clay Mineralogy . . . . . . . 108

Structural Relationships... . . . . 110

Slope Form . . . . . . . . . . . . 112

PRECIPITATION-INDUCED LANDSLIDES . . . . . . . 115

Precipitation Values Required to Induce . . . . 115

Slope Failure ......... 115

1968-69 Rainfall Season . . . . . . 116

1972-73 Rainfall Season . . . . . . . 117

1982-83 Rainfall Season . . . . . . . 118

1992-93 Rainfall Season .. . . . . . 119

Discussion . . . . . . . . . . . 120

Slope Characteristics of PrecipitationInduced Landslides . . . . . . . . . . . . . . 121

Data Compilation and Manipulation . . . 122

Results . . . . . . . . . . . 122

Slope Angle and Precipitation-
Induced Landslides . . . . . . 122

Slope Aspect and Precipitation-
Induced Landslides. . . . . . 124

Vegetation and Precipitation-
Induced Landslides . . . . . 126 
Interpretation of Results . . . . . . . 126

Slope Angle and Precipitation-
Induced Landslides . . . . . . . 126

Slope Aspect and Precipitation- 128

Induced Landslides . . . . . . . . . 128

Vegetation and Precipitation-

CONCLUSIONS . . . . . . . . . . . . . . . . . . . . 132

REFERENCES CITED . . . . . . . . . . . . . . . . . 140

APPENDIX A. ATTERBERG LIMIT VALUES . . . . . . . . 147

APPENDIX B. RESIDUAL FRICTION ANGLE VALUES . . . . 149

APPENDIX C. INPLACE DRY DENSITY AND NATURAL
MOISTURE CONTENT VALUES . . . . . . . . 150

APPENDIX D. MEDIAN GRAIN SIZE AND PERCENT
CLAY CONTENT VALUES . . . . . . . . . . . 154

APPENDIX E. CLAY MINERALOGY . . . . . . . . . . . . 156

APPENDIX F. STRUCTURAL RELATIONSHIP DATA . . . . . 157 


\section{IIST OF ILLUSTRATIONS}

Figure

Page

1. Site Location Map . . . . . . . . .

2. An Example of an "AND" Boolean Logical Operation . . . . . . . . . . 35

3. Distribution of Slope Angle within the Study Area . . . . . . . . . . . 40

4. Distribution of Landslides with Respect to Slope Angle within the Study Area . . . . . . . . . . . . . 40

5. Distribution of Slope Angle within the Arastradero Lithofacies . . . . . . .

6. Distribution of Slope Angle within the Stevens Creek Lithofacies.. . . . .

7. Distribution of Landslides with Respect to Slope Angle within the Arastradero Lithofacies . . . . . . . .

8. Distribution of Landslides with Respect to Slope Angle within the Stevens Creek Lithofacies . . . . . . . .

9. Distribution of Slope Aspect within the Study Area . . . . . . . . . . . . .

10. Distribution of Landslides with Respect to Slope Aspect within the Study Area . . . . . . . . . . . . .

11. Distribution of Slope Aspect within the Arastradero Lithofacies . . . . . . .

12. Distribution of Slope Aspect within the Stevens Creek Lithofacies.. . . . . 45

13. Distribution of Landslides with Respect to Slope Aspect within the Arastradero Lithofacies . . . . . . . . .

14. Distribution of Landslides with Respect to Slope Aspect within the Stevens Creek Lithofacies . . . . . . . . 
15. Distribution of Vegetation within

the Study Area . . . . . . . . . . . . . 48

16. Distribution of Landslides with

Respect to Vegetation within the

Study Area . . . . . . . . . . . . . 48

17. Distribution of Vegetation within

the Arastradero Lithofacies . . . . . . . 49

18. Distribution of Vegetation within

the Stevens Creek Lithofacies... . . . 49

19. Distribution of Landslides with

Respect to Vegetation within the

Arastradero Lithofacies . . . . . . . . 50

20. Distribution of Landslides with

Respect to Vegetation within the

Stevens Creek Lithofacies . . . . . . . 50

21. Pre-Edited Plot of a Portion of the

Landslide Potential Map . . . . . . .

22. Distribution of Landslides with Respect

to the Angle from Parallelism . . . . . 96

23. Distribution of Precipitation-

Induced Landslides with Respect to

Slope Angle within the Study Area . . . .

24. Distribution of Precipitation-

Induced Landslides with Respect to

Slope Aspect within the Study Area . . . 125

25. Distribution of Precipitation-

Induced Landslides with Respect to

Vegetation within the Study Area . . .

Plate

1. Bedrock Geology and Landslide

Distribution Map . . . . . . . . in pocket

2. Generalized Vegetation Map . . . . . in pocket

3. Landslide Potential Map . . . . . . in pocket

xii 


\section{LIST OF TABLES}

Table

Page

1. Distribution of Slope Aspect with Respect to Slope Angle within the Study Area...

2. Distribution of Slope Angle with Respect to Slope Aspect within the Study Area . . 53

3. Distribution of Slope Aspect with Respect to Slope Angle within the Arastradero

Lithofacies . . . . . . . . . . . . 54

4. Distribution of Slope Aspect with Respect to Slope Angle within the Stevens Creek

Lithofacies . . . . . . . . . . . . . . .

5. Distribution of Slope Angle with Respect to Slope Aspect within the Arastradero Lithofacies . . . . . . . . . . . . 55

6. Distribution of Slope Angle with Respect to Slope Aspect within the Stevens Creek Lithofacies . . . . . . . . . . . . . 55

7. Distribution of Slope Angle with Respect to Vegetation within the Study Area..

8. Distribution of Vegetation with Respect to Slope Angle within the Study Area...

9. Distribution of Slope Angle with Respect to Vegetation within the Arastradero Lithofacies . . . . . . . . . . . . .

10. Distribution of Slope Angle with Respect to Vegetation within the Stevens Creek Lithofacies . . . . . . . . . . . . . .

11. Distribution of Vegetation with Respect to Slope Angle within the Arastradero Lithofacies

12. Distribution of Vegetation with Respect to Slope Angle within the Stevens Creek Lithofacies . . . . . . . . . . . . . .

13. Distribution of Slope Aspect with Respect to Vegetation within the Study Area . . 
14. Distribution of Vegetation with Respect to Slope Aspect within the Study Area . .

15. Distribution of Slope Aspect with Respect to Vegetation within the Arastradero Lithofacies . . . . . . . . . . . . . .

16. Distribution of Slope Aspect with Respect to Vegetation within the Stevens Creek

Lithofacies

17. Distribution of Vegetation with Respect to Slope Aspect within the Arastradero

Lithofacies

18. Distribution of Vegetation with Respect to Slope Aspect within the Stevens Creek Lithofacies . . . . . . . . . . . . . .

19. Combined Hazard Values Comprising the Four Failure Frequency Categories . . . . . .

20. Statistics of Liquid Limit and Plastic Limit Values.............. . 86

21. Statistics of Residual Friction Values . . 87

22. Statistics of Inplace Dry Density Values . 88

23. Statistics of Natural Moisture Content Values........ . . . . . . . 89

24. Statistics of Percent Clay Content values... . . . . . . . . . . . 90

25. Statistics of Median Grain Size Values . . 90

26. Abundance of Kaolinite, Illite, and Smectite.............. . . 92

27. Relative Abundance of Kaolinite, Illite, and Smectite. . . . . . . . . . . . . 93

28. Distribution of Profiles of Landslides within the Study Area . . . . . . . . 97

29. Distribution of Profiles of Landslides within the Arastradero Lithofacies . . . . 98

30. Distribution of Profiles of Landslides within the Stevens Creek Lithofacies

$$
\text { xiv }
$$


31. Distribution of Profiles of Shallow

Landslides . . . . . . . . . . . . . . 99

32. Distribution of Profiles of Deep

Landslides . . . . . . . . . . . . . . . 99

33. Summary of the Relative Factor Influence on Slope stability . . . . . . . . . . . . 132

34. Relative Ranking of Factor Subclasses Based on Their Influence on Slope Stability . . . . . . . . . . . . . . 134

35. Summary of the Range of Geotechnical Values for Stable, Potentially Unstable, and Unstable Sample Types . . . . . . . . 136 


\section{ABSTRACT}

The Saratoga Foothills, partially underlain by the weakly lithified, Plio-pleistocene Santa Clara Formation, have historically experienced slope instabilities. Geology, slope angle, slope aspect, vegetation, geotechnical properties, structural relationships, slope profile, and precipitation were investigated to determine which parameters have the greatest impact on slope stability.

Vegetation is the controlling factor within the study area. Slope failures are twice as common on grass-covered slopes as on forest- and brush-covered slopes. In addition, slope failures are twice as common on south-facing slopes, which are primarily grass-covered, as on the typical forestand brush-covered, north-facing slopes. Landslide occurrence is essentially uniform throughout the range of slope angles; the failed percentage of each slope angle interval remains relatively consistent. The disparity in the occurrence of landslides between the two lithostratigraphic units (Arastradero and Stevens Creek) primarily reflects the difference in vegetation distribution, as opposed to lithologic properties. Bedding attitudes in relation to slope inclination have no apparent effect on slope stability.

Typically, slopes in the area have convex upper segments, planar mid slopes, and concave lower parts. Landslides are more common along mid slopes and are rare on upper slopes. 
Samples collected from landslide scarps and failure planes exhibited higher Liquid Limit and Plastic Limit values, lower residual friction angle values, higher percentages of clay, and smaller median grain size than samples collected from areas unaffected by slope instability. All samples contained similar ratios of the clay minerals kaolinite, illite, and montmorillonite.

Although vegetation, geotechnical properties, and slope profile are key factors controlling where landslides occur, precipitation is the controlling factor in determining when failures occur. From 1962 through 1993, in seasons when precipitation totals exceeded $762 \mathrm{~mm}$, landslides occurred in greater numbers than in seasons with lesser rainfall. These landslides tended to form after pre-storm precipitation exceeded $250 \mathrm{~mm}$ and storm totals exceeded $150 \mathrm{~mm}$. Information gathered on the geologic, slope angle, slope aspect, and vegetal characteristics of slope failures within the study area was used to make a predictive map of landslide hazards. The Landslide Potential Map, based on the combined failure frequencies of these properties, illustrates areas of relatively high and low stability within the area of study. 


\section{INTRODUCTION}

As residential development progresses in the foothills surrounding the Santa Clara Valley, it is apparent that a better understanding of the slope stability characteristics of this region is required in order to avoid costly developmental mishaps. Much of this development is occurring in the foothills of western Santa Clara Valley, which is partially underlain by the weakly lithified, Plio-Pleistocene Santa Clara Formation (Vanderhurst, 1981). The Santa Clara Formation, especially in the vicinity of Saratoga and Cupertino, has historically experienced slope instabilities. This region's susceptibility to slope failure is attributable to many interrelated factors: topography; climate; seismicity; human activities; susceptible rock types; thick, unconsolidated colluvial deposits; thick, weathered zones on slopes; bare slopes; expansive clay; and active erosion (Cummings, 1968).

It is common practice to calculate slope stability based on engineering properties for specific sites; however, it would not be feasible to apply such methods on a regional scale. Therefore, some other means of estimating slope stability is desirable for regional evaluation. The natural stability factors and an assessment of their combined influence can commonly be determined by examining existing slope failures. Slopes that have failed indicate where the critical limits of control have been exceeded. Therefore, an 
analysis of landslides and their causes provides information from which the stability of neighboring slopes can be appraised .

\section{Purpose of Study}

The purpose of this study was to determine which natural stability factors are most characteristic of failed slopes within the study area. The factors considered were geology, slope angle, slope aspect, vegetation, geotechnical properties, structural relationships, and slope form. These factors have been identified as being critical stability parameters in studies conducted both locally (Cummings, 1972) and in various regions throughout the world (RadbruchHall and Varnes, 1976). A map showing potential for slope instability was created from the extrapolation of data from selected factors. In addition, the ability of precipitation to initiate slope failure was investigated.

\section{Scope of study}

This study was divided into three sections based on the manner in which the factors where evaluated: "Regional Investigation," "Site-Specific Investigation," and "Precipitation-Induced Landslides." The factors of geology, slope angle, slope aspect, and vegetation were included in the section "Regional Investigation." These factors were addressed in this section because it was possible to represent their spatial distribution on a digitized topographic base 
map. By superimposing information of the various factors on a landslide distribution map, it was possible to determine which factors were most commonly associated with landslide occurrence. This information was used to establish hazard ratings for a map of slope instability potential.

The factors of geotechnical properties, structural relationships, and slope form were included in the section "Site-Specific Investigation." These factors were investigated on a site-by-site basis because heterogeneities in soil properties and slope form make it difficult to evaluate their distribution on a regional scale. For these factors, values or attributes were determined that were characteristic of unstable slopes.

The factor of precipitation was investigated in the section "Precipitation-Induced Landslides." Threshold values for pre-storm and storm rainfall required to initiate slope failure were examined. Individual landslides triggered by precipitation were investigated to determine why these slopes were susceptible to rainfall-induced failure. 
REGIONAL SETTING

\section{Location}

The study area lies in the foothills of northwestern Santa Clara County just west to northwest of Saratoga (Fig. 1). This area is a portion of the Cupertino 7.5 minute quadrangle and includes sections of Saratoga, Cupertino, and unincorporated Santa clara county. It is roughly rectangular in shape and contains an area of about $25 \mathrm{~km}^{2}$. Saratoga-Sunnyvale Road and the Monta Vista fault form the eastern boundaries and the Berrocal fault forms the western border (Vanderhurst, 1981). The study area extends from Permanente in the north to Big Basin Way in the south.

\section{Physiography}

The study area is located in the foothills and lower mountainous region of the eastern flank of the Santa Cruz Mountains. The foothills are underlain by the relatively young santa Clara Formation, composed of weakly lithified, easily eroded sedimentary rocks. The northwest-trending cuesta ridges comprising the study area are bounded to the east and west by the Berrocal fault system (Plate 1). The deep, narrow canyons and oversteepened slopes are the result of Pleistocene uplift in the Santa Cruz Mountains (Vanderhurst, 1981). The gentler slopes and rounded hills in the southern portion of the study area reflect the presence of easily erodible, clay-rich rocks. Relief ranges from $110 \mathrm{~m}$ 


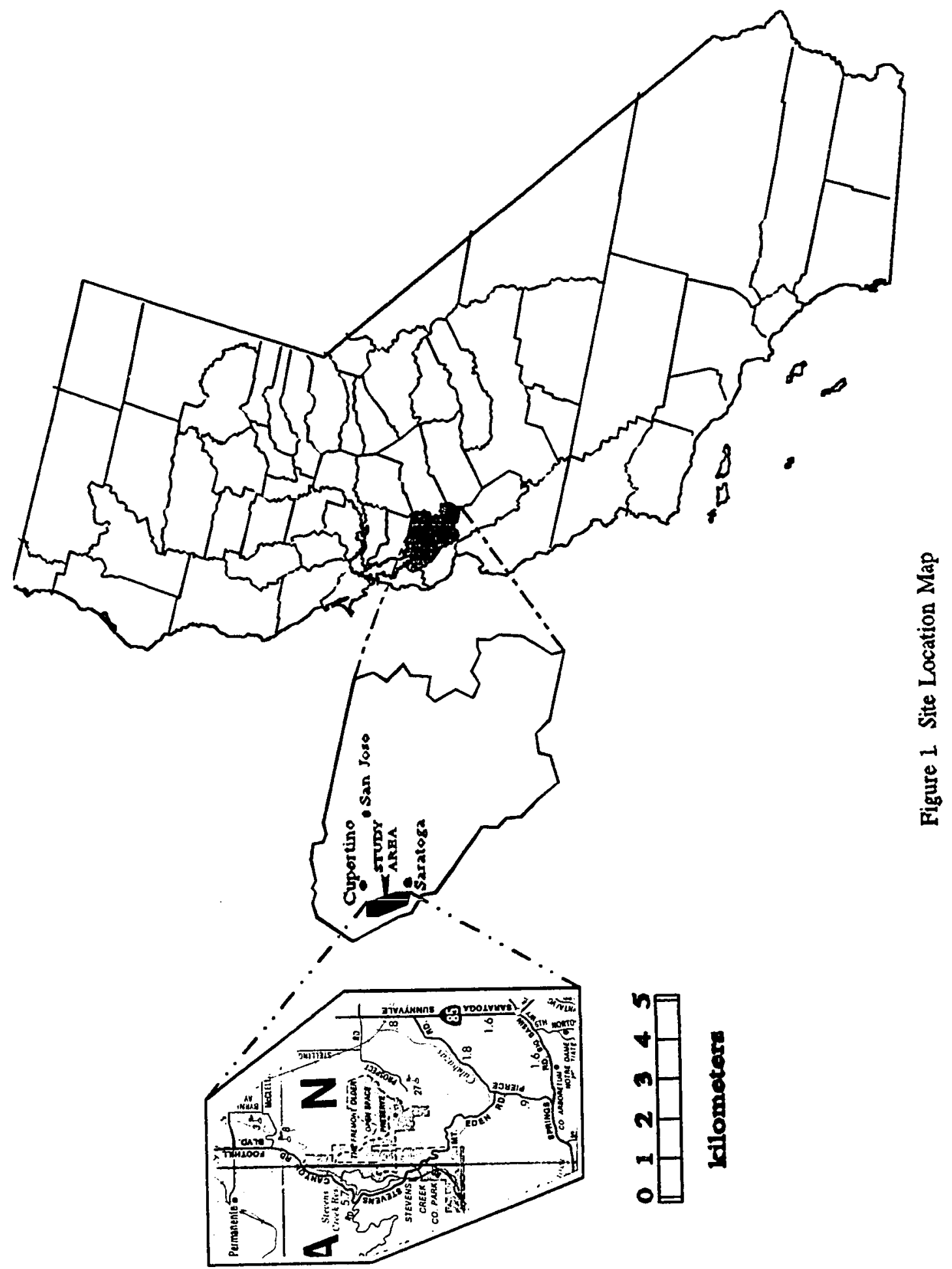




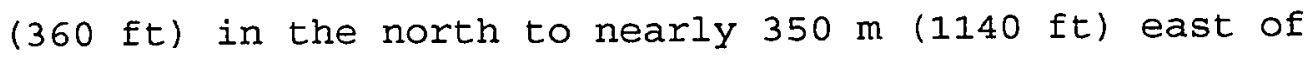
Stevens Creek County Park.

To the west of the study area are the steep, rugged slopes of the Santa Cruz Mountains. These high-relief, northwest-trending ridges are underlain by the upper Mesozoic Franciscan Complex and older Tertiary rocks (Plate 1). East of the study area, the gentler range-front slopes are covered by older Quaternary non-marine terrace deposits and alluvial fans. Younger fan and floodplain deposits overlie the valley floor.

\section{Geology of the Santa Clara Formation}

\section{Previous studies}

Cooper (1894) first used the name "Santa Clara" to describe a sequence of upper Cenozoic non-marine sedimentary rocks in the southern San Francisco Bay area. The Santa Clara Formation was first mapped and assigned a Plio-Pleistocene age by Branner and others (1909). Dibblee (1966) described the type section from a 700-m-thick outcrop west of Stevens Creek Reservoir. Based on compositional differences in conglomerate clasts, Cummings (1968, 1972) proposed eight mappable lithofacies within the Santa Clara Formation. Numerous landslides have been mapped within the formation by Rogers and Armstrong (1973), Sorg and McLaughlin (1975), and Vanderhurst (1981). 


\section{General Statement}

The Plio-Pleistocene Santa Clara Formation is exposed as both a continuous belt and as discontinuous units. The continuous belt, located in the foothilis of the Santa Cruz Mountains, is approximately $1-3 \mathrm{~km}$ wide and extends from near Los Gatos northward through the foothills east of Monte Bello Ridge, near Palo Alto and Portola Valley. The discontinuous units are found along the trace of the San Andreas fault, north of its intersection with the Pilarcitos fault northward to Crystal springs (Vanderhurst, 1981). The geology of the study area is shown in Plate 1 .

The Santa Clara Formation is an accumulation of fluvial deposits composed predominantly of conglomerate, with lesser amounts of sandstone and fine-grained rocks. The strata are weakly indurated, with the clasts being embedded in a friable matrix of sand, silt, clay, iron oxide, or locally, calcium carbonate. It is likely that the majority of the formation was deposited between three million and one million years before present (Vanderhurst, 1981).

The Santa Clara Formation is broadly folded, exhibiting steeply dipping strata and locally overturned beds. The Santa Clara Formation has been offset by faults that have displaced the strata against Miocene marine rocks and the upper Mesozoic Franciscan Complex, which unconformably underlie the Santa Clara Formation. The underlying Miocene rocks are discontinuously exposed in a narrow belt along the mountain front at the northeastern edge of the study area. 
Relatively thin and undeformed late Pleistocene terrace deposits unconformably overlie the Santa Clara Formation.

Cummings (1968, 1972) established eight mappable lithostratigraphic units within the Santa Clara Formation that may be distinguished from one another by differences in clast composition, texture, and other characteristics. Although some of the lithofacies exist as isolated units, many display either gradational or unconformable contacts with other lithofacies of the formation. Based upon the composition of the clasts in the conglomerates, the part of the formation within the study area is divided into three lithofacies: the Arastradero, the Stevens Creek, and the Searsville. The searsville lithofacies is excluded from this study because of its limited exposure and lack of slope failures.

Arastradero Lithofacies. The upper Pliocene Arastradero lithofacies is the oldest and most widespread of the lithofacies exposed along the western edge of Santa Clara Valley. In the study area, the Arastradero occurs as a discontinuous belt bounded to the west by the Berrocal fault and Franciscan rocks and to the east by younger lithofacies of the Santa Clara Formation. Miocene marine formations unconformably underlie the Arastradero, and Quaternary alluvial deposits unconformably overlie this lithofacies. Younger lithofacies of the Santa Clara Formation conformably overlie 
the Arastradero. The thickness of the Arastradero lithofacies ranges from $30 \mathrm{~m}$ to $700 \mathrm{~m}$ (Vanderhurst, 1981).

The Arastradero lithofacies is a sequence of poorly lithified conglomerate, sandstone, siltstone, mudstone, and claystone. The predominant rock type is a moderately-sorted pebble conglomerate with a moderately sorted, medium-grained sandstone matrix. Mudstone and claystone make up a minor portion of the Arastradero and occur as interbeds with poorly sorted sandstone or as very thin, discontinuous beds or lenses. Locally, mudstone occurs as massive tabular beds at least $15 \mathrm{~m}$ thick and traceable for over $1 \mathrm{~km}$. The Arastradero apparently was deposited in an extensive, coarsegrained, braided stream environment with minor associated floodplain and lacustrine environments (Vanderhurst, 1981).

A number of landslide deposits overlie portions of the Arastradero lithofacies. These landslides have been classified as ancient, dormant, and active (Vanderhurst, 1981). The occurrence of landslides in this lithofacies usually reflects the type of underlying material, with most laridslides occurring in mudstone and claystone, where these rocks weather into expansive clays (Sorg and McLaughlin, 1975). In most cases, the ancient landslide deposits have been dissected and eroded by modern fluvial processes. The dormant and modern landslides generally are smaller in extent and thickness than the ancient landslide deposits and usually exhibit common landslide morphology. 
Stevens Creek Itthofacles. The lower to middle Pleistocene Stevens Creek lithofacies is exposed as a continuous, northwest-trending belt $8 \mathrm{~km}$ long by $3 \mathrm{~km}$ wide. The belt is bounded to the east by the Berrocal fault system and rocks of the Franciscan Complex and to the west by the Monta Vista fault and younger valley fill sediments. Locally, the Stevens Creek is in unconformable contact with Miocene marine rocks. The stevens Creek typically overlies or interfingers with the Arastradero lithofacies. Overlying the Stevens Creek are younger alluvial terrace and fan deposits. The thickness of the stevens Creek ranges from $300 \mathrm{~m}$ to $700 \mathrm{~m}$ (Vanderhurst, 1981).

The Stevens Creek lithofacies is a sequence of moderately indurated conglomerate, sandstone, siltstone, mudstone, and claystone. The predominant rock type is a poorly to moderately sorted pebble and cobble conglomerate with a matrix that ranges from poorly sorted, coarse-grained sandstone to mudstone. Fine-grained rocks, especially siltstone, are common in the lower $100 \mathrm{~m}$ of the section and occur as thin, tabular caps on sandstone units. Locally, massive, tabular beds of mudstone up to $50 \mathrm{~m}$ thick are found. The stevens Creek appears to consist primarily of fluvial and debris-flow deposits (Vanderhurst, 1981).

In general, landslide deposits are more prevalent in the Stevens Creek than in the Arastradero lithofacies. steeper topography and adverse structure are believed to be the cause of this (Vanderhurst, 1981). Landslides occurring 
in the Stevens Creek differ from those in the Arastradero lithofacies in that they appear much younger and many are marginally stable to active (Vanderhurst, 1981). The landslides encountered in the stevens Creek lithofacies typically exhibit steep headwall scarps, hummocky topography, enclosed depressions, and springs.

\section{Structure}

The Sargent-Berrocal fault system is a northwesttrending zone of west-dipping, high-angle reverse faults along the eastern base of the Santa Cruz Mountains. This fault system extends from San Juan Bautista north to Palo Alto, where it appears to join the San Andreas fault (McLaughlin, 1974). Within the area of study, the Berrocal fault system forms a $3-\mathrm{km}$-wide fault zone with the southwest block of Monte Bello Ridge and portions of the foothills being uplifted and thrust over the northeast block of the lower foothills and Santa Clara Valley (Rogers and Armstrong, 1973). The Berrocal fault zone in the study area is divided into two distinct traces: the Berrocal fault and the Monta Vista fault.

The compressive stresses associated with the thrusting have created broad, sinuous folds and steeply dipping, locally overturned beds in the Santa Clara Formation (Vanderhurst, 1981). The fold axes are generally subparallel to the Berrocal fault, except near the southern 
end of the study area, where folds appear to trend more east-west. Folds are most common in a zone roughly $1-\mathrm{km}$ wide northeast of the Berrocal fault.

Berrocal Fault. Within the study area, the Berrocal is a reverse fault, dipping 50-60 to the west, with several splinter faults forming a fault zone up to $200 \mathrm{~m}$ wide (Vanderhurst, 1981). It is best exposed along the southwest edge of Mount Eden Valley, where it forms a distinct linear break in topography and vegetation. Between Saratoga and Permanente creeks (Plate 1), the Berrocal fault zone is characterized by several N35W-trending splays separating uplifted Franciscan rocks on the west from down-dropped Santa Clara Formation rocks on the east. Along branch faults east of the main trace, several fault-line scarps have formed, some nearly $10 \mathrm{~m}$ high.

North of Mount Eden Valley, the fault lies in a steepwalled canyon south of Stevens Creek. Where it crosses the concealed fault trace, stevens Creak makes a sharp $90^{\circ}$ bend. A large ancient landslide deposit covers the Berrocal fault southwest of Stevens Creek Reservoir. Numerous enclosed depressions and linear ridges in the landslide deposit overlie the projected fault trace, suggesting that the fault may cut the deposit. However, these features may be coincidental as they are common geomorphic features in landslide deposits (Vanderhurst, 1981). 
The minimum amount of Pleistocene offset on the Berrocal fault in the study area has been estimated to be approximately $1.5 \mathrm{~km}$ (Vanderhurst 1981), while other research suggests that as much as $2.7 \mathrm{~km}$ has occurred (Fleck, 1967). Currently, there is debate as to the present activity of the Berrocal fault. However, micro-seismicity near Stevens Creek Reservoir suggests that the fault may be potentially active (Brown and Lee, 1971). Furthermore, a recent study of western Santa Clara Valley by William Lettis and Associates indicates that active zones of deformation are forming along the Monta Vista fault near the northern portion of the study area and the Berrocal fault near the southern portion of the study area (Chui, 1994).

Monta Vista Fault. The Monta Vista fault is the easternmost surficial trace of the Berrocal fault system in the area of study, where it occurs as a fairly consistently N45W-trending reverse fault with dips ranging from 35-40。 to the west (Vanderhurst, 1981). The fault extends south from Permanente Creek along the front of the Cupertino foothills to Prospect Road, where it becomes concealed by older alluvial deposits northwest of Saratoga. The western block consists of uplifted Santa Clara Formation and Miocene marine rocks, whereas the eastern block is composed of downdropped alluvial deposits of various ages. Southeast of Permanente Creek, the Monta Vista fault is imbricated, with a sliver of Monterey Formation having been thrust between 
the Santa Clara Formation and alluvial deposits (Rogers and Armstrong, 1973). Uplift on the southwest block of the Monta Vista fault in the Stevens Creek Canyon area has rejuvenated Stevens Creek, allowing down-cutting and the deposition of numerous terrace deposits up to $60 \mathrm{~m}$ higher than the present elevation of Stevens Creek (Vanderhurst, 1981). Locally, the Monta Vista fault is buried under older alluvial deposits and deep colluvial soils. The easternmost trace of the fault has offset fan material with a radiocarbon age of 23,000 years before present (Vanderhurst, 1981). Rupture zones seen in exploratory trenches are up to $10 \mathrm{~m}$ wide.

other Faults. Within the study area, secondary faults are sub-parallel to the Berrocal and Monta Vista faults. These faults typically are discontinuous, being traceable for less than $1 \mathrm{~km}$ in length. Like the Berrocal and Monta Vista faults, these minor faults exhibit reverse displacement. Evidence of faulting is supported by the occurrence of repeated stratigraphic sections and anomalous bedding attitudes. Vertical displacements on these faults generally are less than $10 \mathrm{~m}$ and probably occurred during the folding of the Santa Clara Formation (Vanderhurst, 1981).

\section{Soils}

The majority of soils within the study area belong to the Soper and Azule soil series. Soper series soils, of the Hillgate-Soper association, mantle the steeper slopes sur- 
rounding Stevens Creek Reservoir. Azule series soils, of the Altamont-Azule association, blanket the remaining slopes within the study area (Soil Conservation Service, 1941). Soper series soils are represented almost entirely by the soper gravelly loam. This soil type is composed of gravelly loam surface soils and gravelly clay loam subsoils. The depth to the weakly consolidated sandstone and conglomerate substratum averages $1 \mathrm{~m}$ (40 in), while the depth to hard bedrock generally is in excess of $1.5 \mathrm{~m}(5 \mathrm{ft})$. The Soper gravelly loam is well drained with moderately low subsoil permeability. This soil exhibits moderate shrinkswell behavior. Runoff from this soil is moderately rapid and the erosion hazard is high, with areas of severe sheet and gully erosion found locally (Soil Conservation Service, 1968).

Both the Azule clay loam and the Azule silty clay loam soil types are present within the study area; the former covers the steeper slopes, while the latter blankets the more gentle slopes. Both soil types are composed of clay loam or silty clay loam surface soils and gravelly sandy clay subsoils. The depth to the stratified, semiconsolidated, soft-sediment substratum averages $1.2 \mathrm{~m}(48$ in), while the depth to hard bedrock is in excess of $1.5 \mathrm{~m}$ (5 ft). Both soil types are well drained with low subsoil permeability and typically exhibit high shrink-swell behavior. The Azule clay loam is characterized by rapid to very rapid runoff and a high to very high erosion hazard, whereas 
the Azule silty clay loam has moderate runoff and a moderate erosion hazard. Small "landslips," gullied land, and severe sheet erosion comprise about $10 \%$ of the Azule series soils (Soil Conservation Service, 1968).

\section{Vegetation}

The vegetal cover of the study area can be separated into six main categories. Four of the categories consist of native vegetation and include grassland, "grass-oak" land, brushland, and woodland. '.'he other two, residential landscaping and agricultural land, have replaced a significant portion of the native vegetation.

Grassland commonly occurs on the lower foothills and on gentle slopes throughout the study area. The grassland vegetation is composed predominantly of annual grasses, especially oats, bromegrass, and foxtail fescue. Forbs, such as clover and burclover, commonly are associated with the grasses.

A vegetal class of "grass-oak," named after a Soil Conservation service resource area, commonly covers gentle to moderately steep, easterly slopes in the study area. "Grass-oak" areas are composed of open stands of woodland trees, especially oaks, with an understory of grasses and forbs (Soil Conservation Service, 1968) and are referred to as scattered brushland/woodland below. 
Brushland, or chaparral, is found on steeper slopes, especially those facing south and east, and consists of woody shrubs. Manzanita, scrub oak, Jimbrush, birchleaf mountain mahogany, and poison oak are the major florae. In many areas, brushland vegetation has replaced native woodland and grassland cover (Soil Conservation Service, 1968). woodland vegetation typically covers steep, northfacing and protected slopes, although smaller stands are found locally along stream courses. Woodland vegetation is composed predominantly of various oaks, madrone, maple, and California laurel, with rarer stands of redwoods. Within the study area, these broad-leaved or hardwood trees form moderately dense, closed-canopy stands. Non-native eucalyptus trees commonly are found near residential developments. Many areas, especially along the eastern and southern margins of the study area, have been stripped of their native vegetation as residential development spreads throughout the ioothills. Land once covered by grassland and "grass-oak" vegetation, and later by agricultural land, has been denuded except for residential landscaping.

Agricultural land covers much of the flat, low-lying areas of the foothills, especially in the eastern and southern portions of the study area. This land is used mainly for orchards, vineyards, and grain hay. The majority of the agricultural land was covered by grassland or "grass-oak" vegetation prior to its conversion to agricultural use (Soil Conservation Service, 1968). 
Precipitation

Moderate temperatures and light to moderate rainfall, characteristic of Mediterranean climates, are typical for Santa Clara County. Within the study area, rainfall ranges from about 350-460 mm/yr (14-18 in/yr) along the eastern margin to about $600-760 \mathrm{~mm} / \mathrm{yr}(24-30 \mathrm{in} / \mathrm{yr})$ in the higher, more westerly areas (San Jose Mercury News, 1993). In the autumn and winter months, from October through March, this region receives about $90 \%$ of its annual totals (Rantz, 1971). 


\section{CRITICAL FACTORS CONTROLLING SLOPE INSTABILITY}

Seldom can a landslide be attributed to a single definitive cause. In fact, the majority of landslides are the result of the combined effects of a number of internal and external factors. As a result, it is important to consider a number of individual factors and the interrelations among those factors before a potentially unstable slope can be recognized. Although there are a multitude of factors promoting slope instability, relatively few are significant at individual sites or in specific regions. For example, after a regional investigation of a portion of Calabria, Italy, Carrara and others (1977a) determined that only about 30 of the studied 100 factors were significant contributors to slope instability.

Regardless of where a study area is located, a number of similar factors are common to most slope stability investigations (Radbruch-Hall and Varnes, 1976). This paper will investigate these commonly cited factors, as well as those that have been determined to be especially significant within the subject study area.

\section{Geology}

The geologic map is a commonly used tool in the disciplines of urban planning and engineering geology. Because geologic maps provide information on the lithology and structural setting of an area, a number of generalizations can be extracted from them. Lithologic units depicted on 
geologic maps often give an indication of the strength, erodibility, and engineering properties of the rocks (Anbalagan, 1992). Mapped structures, such as bedding planes, joints, and faults, can provide insight on the relationships between structural discontinuities and slope inclination.

\section{Slope Angle}

Slope angle is an important, if often misunderstood, factor in controlling landslide occurrence. Very steep slopes are often viewed as a significant threat to slope stability. However, Radbruch and Crowther (1973) determined that the majority of landslides throughout California occur on slopes between 5 and 35 degrees. Similarly, Carrara and others (1977b) determined that landslides in a portion of Calabria, Italy, became statistically uncommon on slopes steeper than 35 degrees. Other researchers (Cleveland, 1971; DeCoster, 1979) have shown that critical slope angles, between which landslides commonly occur, can be determined for individual lithologic units.

A number of theories have been forwarded to explain the minimum and maximum slope angles of landslide occurrence. Very gentle slopes (less than $5^{\circ}$ ) are believed to lack the gravitational forces required to drive landslides. On the other hand, steep slopes are believed to reflect the greater strength of the underlying rocks. Furthermore, continuous removal of colluvium on steep slopes by rain 
wash is believed to prevent the accumulation of thick regolith (Beatty, 1956).

\section{Slope Aspect}

In some regions, recognized relationships exist between landslide occurrence and slope aspect. Slope aspect is considered to be an important factor because of its relationship to moisture content, vegetation, and local structures or drainage patterns. Beatty (1956) observed that the majority of landslides near the Berkeley Hills, California, occurred on slopes with northerly and easterly orientations. He attributed this to the higher moisture content in these slopes, which are less exposed to the sun. Other researchers (Kardos and others, 1943; Huma and Radulescu, 1978) have attributed the abundance of landslides on north-facing slopes to the added overburden weight of accumulated snowfall and the increase in moisture in those slopes. In Calabria, Italy, Carrara and others (1977a) discovered that slope failures were, in part, controlled by drainage orientations and were related to the undercutting of the toes of slopes by stream erosion.

\section{Vegetation}

The stabilizing affect of vegetation on slopes has long been the subject of controversy (Prandini and others, 1977). In general, the majority of researchers agree that vegetation represses the action of climatic agents on a slope and 
protects it from the effects of weathering and erosion. In addition, it has been shown that a well-spread root system increases the shearing resistance of the slope material (Prandini and others, 1977). Gray (1973) concluded after his study of the effects of forest clear-cutting on slope stability that "forest plays an important role in the protection of soil, and deforestation can bring about not only erosion, but also collective soil movements." In fact, many researchers have reported that the occurrence of landslides generally increases as vegetation becomes more sparse.

One of the more interesting dissenting opinions resulted from the investigation of the effects of deforestation on slopes by Brown and Sheus (1975). They argue that the additional overburden provided by the weight of the vegetation and the action of the wind applying a levering effect on trees tend to decrease the stability of a slope.

\section{Geotechnical Properties}

One important goal in evaluating geotechnical properties is to determine values that represent the limits of stability of a slope, given certain site-specific conditions. As used in this study, "geotechnical properties" refer to selected engineering, physical, and mineralogical properties that directly or indirectly give an indication of the strength of the earth material.

Residual shear strength is considered to be an important engineering parameter for slope stability analysis 
because it defines the minimum shearing resistance along the failure plane of a landslide mass. A great deal of research has gone into the correlation between shear strength and Atterberg Limits. Researchers, such as Bjerrum and Simons (1960), Lo (1962), and Kanji (1974), have determined that internal friction angles can be approximated from the Dlasticity Index of a soil. In addition, Kenny (1967) and Voight (1973) discovered that residual shear strength is a direct indication of the type of clay minerals present in a sample.

One of the more useful applications of geotechnical investigations is for engineering and urban planning purposes. It has become commonplace to carry out detailed engineering geological investigations to provide information on the physical environment and geotechnical characteristics of an area prior to any urban development. In an example from Tenerife, the Canary Islands, engineering geology and urban suitability maps were developed after gathering field and laboratory information on compressive and shear strengths, compaction and swelling characteristics, grain size distribution, Atterberg Limits, and inplace dry density (Gonzalez de Vallejo, 1977).

\section{Structural Relationships}

A large portion of the fields of soil and rock mechanics has been devoted to the study of hazards arising from geometric relationships of structural discontinuities. 
Under the proper conditions, a coincidence between bedrock orientation and slope inclination has been shown to promote slope failures. Excluding the influence of such external stimuli as seismicity and pore pressure, three criteria must be met to establish a potentially unstable environment for a bedding plane failure: 1) the single plane on which sliding occurs must strike parallel or nearly parallel $\left( \pm 20^{\circ}\right)$ to the slope face; 2) the dip of the strata must be less than the dip of the slope face ("day-lighting" failure plane); and 3) the dip of the failure plane must be greater than the angle of friction on this plane (Hoek and Bray, 1974).

The disposition of structural discontinuities in relation to slope inclination has been used in a number of hazard zonation investigations. Anbalagan (1992) assigned a high risk to slopes where the slope face and the discontinuity were nearly parallel (less than $5^{\circ}$ ), with the risk becoming minimal when the intersection exceeded $30^{\circ}$. Anbalagan and other workers (Hoek and Bray, 1974; Chang, 1992) also suggested that dip slopes, those with bedding dips equal to or less than the dip of the slope, pose a larger hazard than oblique slopes or anti-dip slopes.

\section{Slope Form}

The form of a slope is a result of the interaction of geology and climate over time. Slope form can often indicate if a slope is susceptible to instability. Typically, 
slope form is expressed as concave, convex, or rectilinear (straight) and is considered in both plan and profile.

From an engineering standpoint, slopes that are concave in plan view are generally less stable than convex slopes because they tend to retain stress, block internal drainage, and have higher moisture contents near their slope toes. In profile, concave slopes are generally more stable than convex slopes, with the degree of stability increasing as concavity increases or convexity decreases (Hoek and Bray, 1974) .

Slopes that are concave in plan view should be given special attention because of their ability to collect debris. In a study in the northern San Francisco Bay area, California, Reneau and others (1990) discovered that concave topography commonly forces colluvial debris to converge toward the axis of the "colluvial hollow," resulting in long-term deposition. The hollow becomes the site of cyclic accumulation and evacuation of colluvium, with multiple Holocene failures being documented in a number of hollows in the central California Coast Ranges.

\section{Precipitation}

The correlation between precipitation and slope failures is well documented in many areas. In the San Francisco Bay area, during the especially wet winters of 1968-69 and 1972-73, a total of 746 reported landslides resulted in $\$ 35$ million worth of damage (Nilsen and others, 1979). The 
landslides probably were initiated by one or more of the effects of increased water in the subsurface, such as increased overburden weight, decreased friction, increased internal pore pressure, or hydration of clays.

A number of studies have been done in California to determine threshold values of pre-storm (antecedent) and storm precipitation required to initiate landslides. In southern California, Campbell (1975) observed that few landslides occurred until the pre-storm rainfall had reached about $250 \mathrm{~mm}$ (10 in) and the rainfall intensity exceeded $6 \mathrm{~mm} / \mathrm{hr}(0.25 \mathrm{in} / \mathrm{hr})$. Mark and Newman (1988) determined that landslides in the San Francisco Bay area formed after pre-storm totals reached $250-380 \mathrm{~mm}$ (10-15 in) and storm totals reached $150-200 \mathrm{~mm}(6-8 \mathrm{in})$. In fact, Radbruch and Crowther (1973) found that very few landslides occur in California in places where mean annual precipitation is less than $250 \mathrm{~mm}$ (10 in). 


\section{REGIONAL INVESTIGATION}

A "regional investigation" was conducted to study the factors of geology, slope angle, slope aspect, and vegetation. The term "regional" is used because the distribution of these factors was spatially represented on a digitized base map. Once the factors were entered into the database, it was possible to manipulate the factor data and to determine various relationships between the factors and the occurrence of landslides. Because the factor data were spatially distributed in a computer database, it was possible to determine the area comprising each of the factor occurrences. After comparing the area comprising each factor in the study area with the area comprising each factor in failed slopes, it was possible to determine the relative contribution to stability of each factor and subclasses of each factor. After examining these relationships, three topics were addressed: 1) the factors most commonly associated with slope failures were identified; 2) interrelationships between factors were evaluated; and 3) a map showing slope instability potential was created.

\section{Data Compllation}

\section{Computer Database}

For this study, a digitized topographic map of the study area was used as a template for overlaying factor data. The elevation contour data were manually digitized from a 1:12000-scale enlargement (hereafter referred to as 
"base map") of the 1:24000-scale Cupertino 7.5-minute quadrangle map. The quadrangle map was enlarged to facilitate the digitizing process. The digitized data were converted from the digitizing board coordinates to their corresponding Universal Transverse Mercator (UTM) coordinates using a spreadsheet program. The converted data were gridded and contoured using the "makeGrid" and "conTour" functions of Gridzo 6.0 $0^{\mathrm{m}}$. A total of 700,000 grid nodes are uniformly spaced in both north-south and east-west directiors, with the distance between adjacent nodes representing a map distance of approximately $6 \mathrm{~m}$. Portions of the digitized base map were compared to the actual topographic map to verify that an accurate representation had been created.

\section{Landslides}

The landslides used for this study were compiled in 1992-1993 from published and unpublished sources onto the base map. The majority of the landslides were taken from the geologic maps of Rogers and Armstrong (1973), Sorg and McLaughlin (1975), and Vanderhurst (1981). Additional landslides came from unpublished reports by cotton and Associates (1980), Terratech (1985), and Nelson (1985). Approximately 60 percent of the landslides were identifiable on 1:12000-scale or 1:24000-scale air photos taken in 1965 and 1980, respectively. Field checks were conducted on about 30 percent of the landslides to verify their existence. Landslides that could not be identified in air- 
photos and/or field checks and also lacked geotechnical evidence were omitted from the study. The distribution of landslides is shown in Plate 1 .

Based on the landslide classification of Varnes (1978), most of the landslides used in this study are rotational, with a small percentage being planar. Rapid slope failures such as avalanches, falls, and flows are excluded from this study. All landslides used in this study have one areal dimension of at least $30 \mathrm{~m}$. The depths of the landslides range from approximately $1.5 \mathrm{~m}$ to $20 \mathrm{~m}$.

The landslides considered in this study were divided into three categories: (1) shallow (less than $3 \mathrm{~m}$ ); (2) deep (greater than $3 \mathrm{~m}$ ); and (3) undifferentiated (no depth data available). Separating landslides by depth was required because it commonly is observed that factors that are significant in promoting slope failures at shallow depths differ from those controlling deeper-seated landslides. This classification scheme is reasonable because the contact between soil and the underlying bedrock appears to occur at an average depth of approximately $3 \mathrm{~m}$ (10 ft) (Soil Conservation Service, 1968; Rogers and Armstrong, 1973); therefore, the division between the two categories roughly separates landslides occurring in soil from those in bedrock. Sources that provided depth estimates included cotton and Associates (1980), Nelson (1985), Terratech (1985), and other unpublished geotechnical reports filed with the County of Santa Clara and Cotton and Associates. The depth esti- 
mates were based on bore hole data, trench data, or field observations.

Once the landslides had been compiled and categorized on the base map, their boundaries were manually digitized into the computer database. The digitized data were converted from the digitizing board coordinates to their corresponding UTM coordinates. The UTM coordinates were converted into polygonal areas using the "polygrid" function of Gridzo 6. $0^{\mathrm{m}}$. Each landslide polygon was assigned a value designating it as either shallow, deep, or undifferentiated. The landslide polygons were superimposed on the digitized base map to form the "landslide data grid."

\section{Geology}

The majority of the geologic information used in this study came from the geologic map of Vanderhurst (1981). Additional faults and bedrock orientations were compiled from Rogers and Armstrong (1973) and geotechnical reports from the files of Cotton and Associates. Field measurements of bedrock orientation were taken during this study where gaps in data were present in critical areas. The geology and structure of the study area are shown in plate 1.

For this study, the contacts between the Arastradero and Stevens Creek lithofacies and the older sedimentary rocks were manually digitized from the geologic map into the computer database. The digitized data were converted from the digitizing board coordinates to their corresponding UTM 
coordinates. The UTM coordinates were converted into polygonal areas using the "polygrid" function of Gridzo 6. $0^{\text {TM }}$. Each lithology polygon was assigned a value designating it as either Arastradero or Stevens Creek. The lithology polygons were superimposed on the digitized base map to form the "geology data grid."

\section{Slope Angle}

The slope angle was calculated for the slopes within the study area using the "sLopeaz" function of Gridzo 6.0 The slope angles, expressed in degrees, were determined by computing the elevation changes between the adjacent grid nodes of the digitized base map. The slope angles were divided into 18 five-degree intervals, starting with $0-5^{\circ}$ and ending with $85-90^{\circ}$. The results were retained as the "slope angle data grid."

\section{Slope Aspect}

The slope aspect, or downhill direction of slope, was calculated for the slopes within the study area using the "sLopeaz" function of Gridzo 6.0 expressed as azimuth degrees, were determined by calculating the changes of slope between neighboring grid nodes of the digitized base map. The slope aspects were divided into eight $45^{\circ}$ octants centering on north, northeast, east, southeast, south, southwest, west, and northwest. The results were retained as the "slope aspect data grid." 


\section{Vegetation}

After a preliminary review of the most recent air photos of the study area (1980), the vegetation of the study area was divided into six categories based on the two primary criteria suggested by Cleveland (1971): root networks and evapotranspiration. The six categories are bare/residential, grassland, scattered brushland/woodland, agricultural, brushland, and woodland. Each category was examined in the field to verify its ability to promote slope stability.

The bare/residential category represents land either lacking all vegetation or covered by residential landscaping such as lawns or ornamental bushes and trees; root strength and water use are low. Grassland vegetation is composed of dense growths of tall grasses, such as oat; root strength and water use are low. Scattered brushland/woodland, which includes "grass-oak" vegetation of the Soil Conservation Service (1968), represents terrain covered by sparsely distributed shrubs or trees; root strength and water use are moderate. Agricultural land is composed of either grain hay fields or dryland orchards; root strength and water use are generally low. Brushland represents terrain covered by dense growths of woody shrubs; interlocking root networks provide moderate strength to depths up to $3 \mathrm{~m}$ and water use is moderate. Woodland vegetation occurs as moderately dense, closed-canopy stands of hardwood trees; interlocking root networks provide high strength to depths up to $18 \mathrm{~m}$ and water use is high. 
Mapping of the vegetation was accomplished using air photos. The vegetal boundaries were delineated using 1:12000-scale air photos taken in 1965. A review of 1:24000scale air photos taken in 1980 was conducted to up-date any large-scale changes in vegetation since 1965. Only minor changes were noted, with the majority being the conversion of agricultural land and grassland to residential.

The vegetation boundary data were plotted onto the base map (Plate 2), which was subsequently digitized into the computer database. The digitized data were converted from the digitizing board coordinates to their corresponding UTM coordinates. The UTM coordinates were converted into polygonal areas using the "polYgrid" function of Gridzo 6.0 Each vegetation polygon was assigned a value designating it as either bare/residential, grassland, agricultural land, scattered brushland/woodland, brushland, or woodland. The vegetation polygons were superimposed on the digitized base map to form the "vegetation data grid."

\section{Data Manipulation}

Boolean Logic

The various relationships determined in the following sections were calculated using the Boolean logical operations of Gridzo 6. $0^{\mathrm{m}}$. The advantage of using this procedure is that it is possible to evaluate the occurrence of multiple factors. These operations included creating Boolean 
grids of "TRUE"/"FALSE" values and comparing Boolean grids using various Boolean mathematical operations.

Boolean Grids. A Boolean grid is a file that contains only two values, "TRUE" and "FALSE." In a Boolean grid file, any node whose corresponding node in the original file has a value that is within a specified range is assigned a value of 1.0 for "TRUE." Any Boolean grid node whose corresponding node has a value that falls outside the specified range is assigned a value of 0.0 for "FALSE."

Boolean grids can be created for both contiguous areas or for randomly distributed nodes. For example, in order to create a "TRUE" Boolean grid for east-facing slopes, a specified azimuth interval of $67^{\circ}-112^{\circ}$ would be imposed on the slope aspect data grid. All grid nodes representing east-facing slopes would be assigned a "TRUE" value (1.0), while the remaining nodes would be assigned a "FALSE" value (0.0). Similarly, to create a "TRUE" Boolean grid for shallow landslides, all grid nodes representing shallow landslides would be assigned a "TRUE" value, while the remaining nodes would be assigned a "FALSE" value.

Boolean Logical Operations. Once Boolean grids have been created, they may be manipulated in a number of ways using Boolean mathematical operations. For this study, it was important to know where "TRUE" values coincided on the various factor grids. Therefore, an "AND" logical operation 
was used. The "AND" operation compares two Boolean grids (GRID A and GRID B) and creates a third Boolean grid (GRID C), as illustrated in Figure 2. The figure shows that a "TRUE" value occurs in Grid $\mathrm{C}$ only where "TRUE" values coincide in Grids $A$ and $B$.

\begin{tabular}{|c|c|c|} 
GRID $A$ \\
\begin{tabular}{|c|c|c|}
\hline$T$ & $T$ & $F$ \\
\hline$T$ & $T$ & $F$ \\
\hline$T$ & $F$ & $F$ \\
\hline
\end{tabular}
\end{tabular}

+
\begin{tabular}{|c|c|c|}
\multicolumn{3}{c}{ GRID } \\
AND & $\mathrm{F}$ & $\mathrm{F}$ \\
\hline $\mathrm{F}$ & $\mathrm{T}$ & $\mathrm{T}$ \\
\hline $\mathrm{T}$ & $\mathrm{T}$ & $\mathrm{T}$ \\
\hline
\end{tabular}

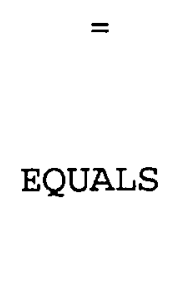

\begin{tabular}{|c|c|c|}
\multicolumn{1}{c}{ GRID $C$} \\
\hline$F$ & $F$ & $F$ \\
\hline$F$ & $T$ & $F$ \\
\hline$T$ & $F$ & $F$ \\
\hline
\end{tabular}

Figure 2. An example of an "AND" Boolean Logical operation. $T=$ "TRUE" value and $F=$ "FALSE" value.

\section{Boolean Grids of Factors}

Using the "Blogic" function of Gridzo 6.0 Boolean grids were created for the sub-classes of each factor. From the "landslide data grid," "TRUE" Boolean grids were created for each category of landslide and one was created representing all three landslide categories. From the "geology data grid," "TRUE" Boolean grids were created for the Arastradero and Stevens Creek lithofacies. From the "slope angle data grid," "TRUE" Boolean grids were created for each of the 18 slope angle intervals. From the "slope aspect data grid," "TRUE" Boolean grids were created for each slope aspect octant. From the "vegetation data grid," "TRUE" Boolean grids were created for each of the six categories of vegetation. 


\section{Example of Evaluation Procedure}

The following is an example of the procedures used to determine the various relationships discussed in this section. This example illustrates how the percentage of eastfacing slopes within the Stevens Creek lithofacies experiencing shallow slope failure was determined. The other relationships were determined using the same procedures, substituting the various factor subclasses as required.

1) Boolean grids were created for the subclasses of "east-facing slopes," "Stevens Creek Iithofacies," and "shallow landslides."

2) the number of grid nodes comprising each subclass was counted and recorded using a counting program written in BASIC. The sums were used to calculate the relative frequency of each of the subclasses.

3) the distribution of east-facing slopes within the Stevens Creek Iithofacies was determined by comparing the "east-facing slopes" and "Stevens Creek lithofacies" Boolean grids using the "AND" Boolean logical operation. The results of the comparison were contained in a third Boolean grid: "east-facing/Stevens Creek."

4) the "TRUE" grid nodes contained in the "eastfacing/Stevens Creek" Boolean grid were counted and recorded. 
5) the distribution of shallow landslides on eastfacing slopes within the Stevens Creek lithofacies was determined by comparing the "shallow landslide" Boolean grid with the "east-facing/Stevens Creek lithofacies" Boolean grid using the "AND" Boolean logical operation. The results of the comparison were contained in the "east-facing/Stevens Creek/ shallow landslide" Boolean grid.

6) the "TRUE" grid nodes contained in the "eastfacing/Stevens Creek/shallow landslide" Boolean grid were counted and recorded.

7) the percentage of east-facing slopes within the Stevens Creek lithofacies that have experienced slope failure was then determined by dividing the sum of the "TRUE" grid nodes in the "eastfacing/Stevens Creek/shallow landslide" Boolean grid (step 6) by the sum of the "TRUE" grid nodes in the "east-facing/Stevens Creek" Boolean grid (Step 4).

\section{Relationships Between Individual Factors and Landslides}

\section{Landslides}

The relative distributions of the three categories of landslides were determined for the slopes within the study area. The percentage of the study area affected by slope failures was determined by dividing the sum of the grid nodes assigned to each category of landslide by the total 
number of grid nodes. The relative frequency of each of the three categories was determined by dividing the grid nodes assigned to each category of landslides by the sum of the grid nodes of all three categories.

Results indicate that a total of $15 \%$ of the study area has experienced recognized slope failure: 5\% of the slopes are occupied by shallow landslides, $6 \%$ by deep landslides, and $4 \%$ by undifferentiated landslides. Each category of landslide is nearly equally represented, with $34 \%$ being shallow, $37 \%$ deep, and $29 \%$ undifferentiated.

\section{Geology}

The areas composed of rocks of the Arastradero and Stevens Creek lithofacies were determined within the study area. This was accomplished by summing the grid nodes assigned to each lithofacies and dividing by the total number of grid nodes. The results indicate that the stevens Creek lithofacies comprises approximately $85 \%$ of the study area and the Arastradero comprises the remaining $15 \%$.

The percentage of each lithofacies affected by slope failure was determined. This was accomplished by comparing the landslide and geology Boolean grids. Geology grid nodes falling within the boundaries of landslides were recorded and summed. The results indicate that $13 \%$ of the stevens Creek and $24 \%$ of the Arastradero slopes have failed. Within the Arastradero lithofacies, $47 \%$ of the landslides are shallow and 53\% are deep. Within the stevens Creek litho- 
facies, $30 \%$ of the landslides are shallow, $31 \%$ deep, and $39 \%$ undifferentiated.

\section{Slope Angle}

The frequency distribution of each slope angle interval and the percentage of each interval that has failed were determined. The distribution of slope angles (Fig. 3) was calculated by dividing the sum of the grid nodes from each interval by the total number of grid nodes. Also included in Figure 3 is the area of each slope angle interval that has experienced slope failure. The failed area was determined by comparing the landslide and slope angle Boolean grids. The slope angle grid nodes falling within the boundaries of landslides were recorded and summed. The relative abundance of shallow, deep, and undifferentiated landslides with respect to slope angle is presented in Figure 4.

For the basis of comparison, the distribution of slope angle in each lithofacies was determined. This was accomplished by including the Boolean geology grids in the above procedures. The frequency distribution of slope angle for the Arastradero lithofacies is presented in Figure 5 and that for the Stevens Creek lithofacies is in Figure 6. Included in each figure is the area of each slope angle interval that has failed. The relative abundance of shallow, deep, and undifferentiated landslides for each slope angle interval is presented in Figure 7 for Arastradero slopes and Figure 8 for Stevens Creek slopes. 


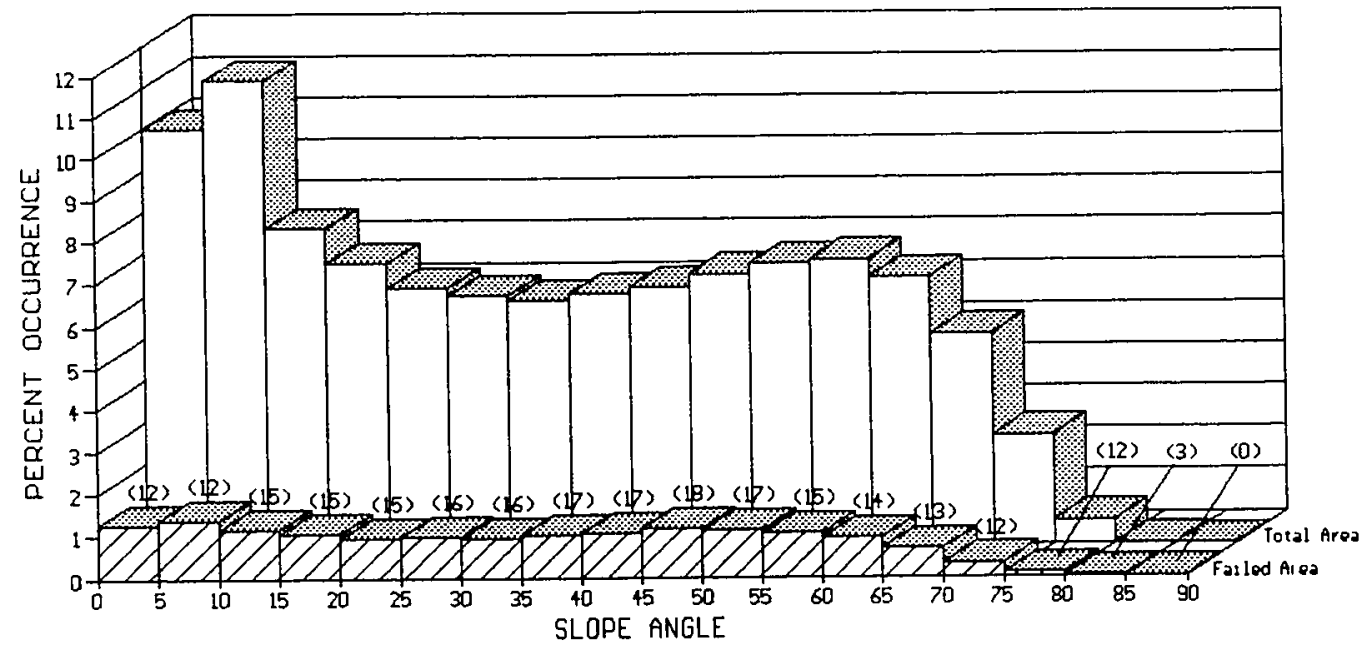

Figure 3. Distribution of slope angle and the failed area of each slope angle interval within the study area. Number in parentheses indicates the failed percentage of each interval.

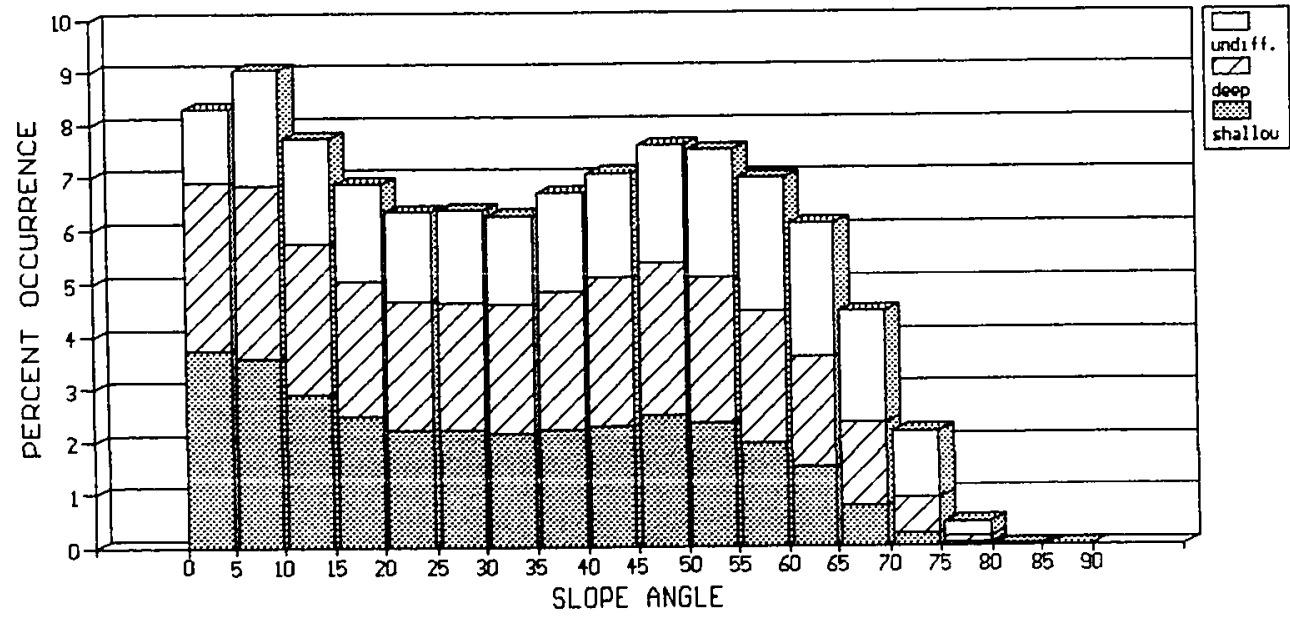

Figure 4. Distribution of shallow, deep, and undifferentiated landslides with respect to slope angle within the study area. Percent occurrence reflects percentage of all landslides. 


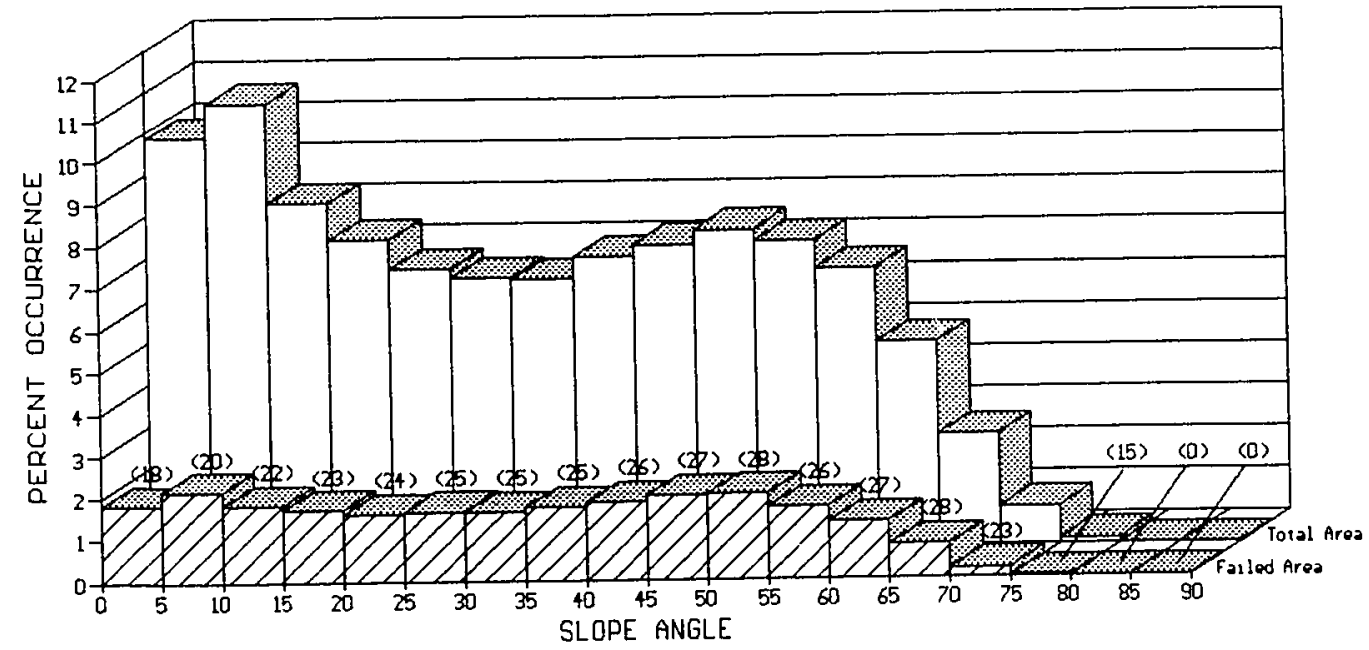

Figure 5. Distribution of slope angle and the failed area of each slope angle interval within the Arastradero lithofacies. Number in parentheses indicates the failed percentage of each interval.

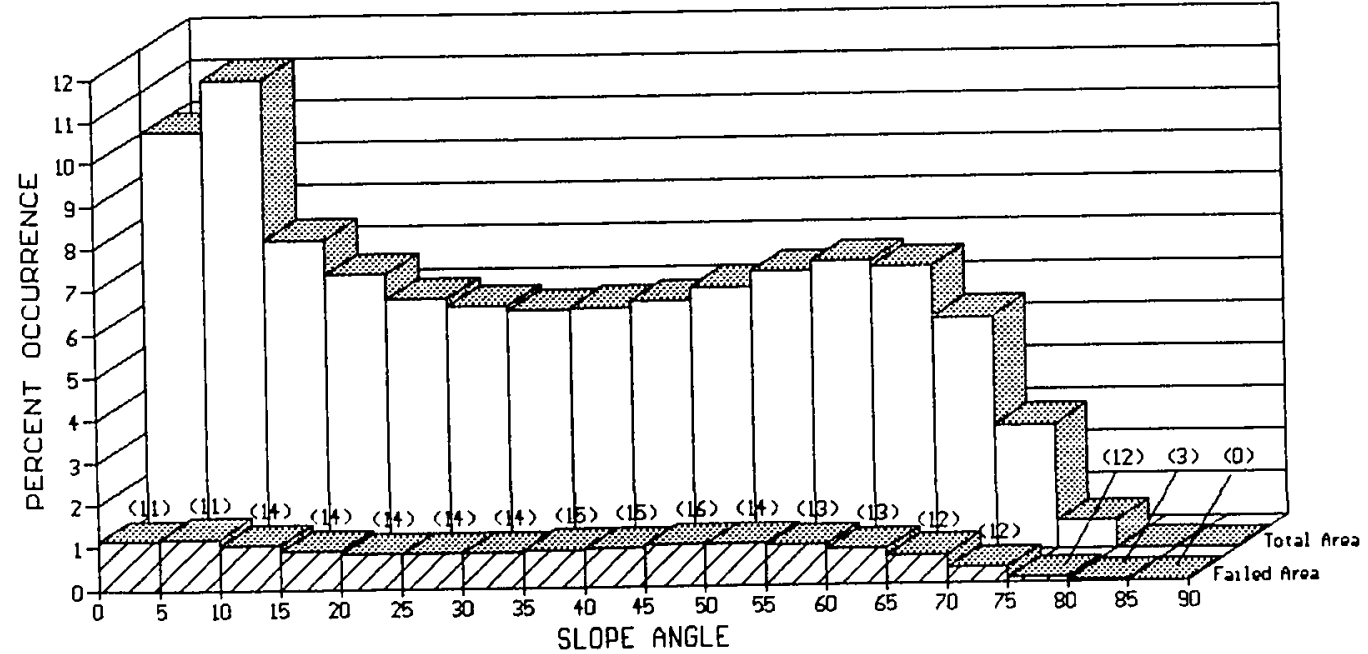

Figure 6. Distribution of slope angle and the failed area of each slope angle interval within the Stevens Creek lithofacies. Number in parentheses indicates the failed percentage of each interval. 


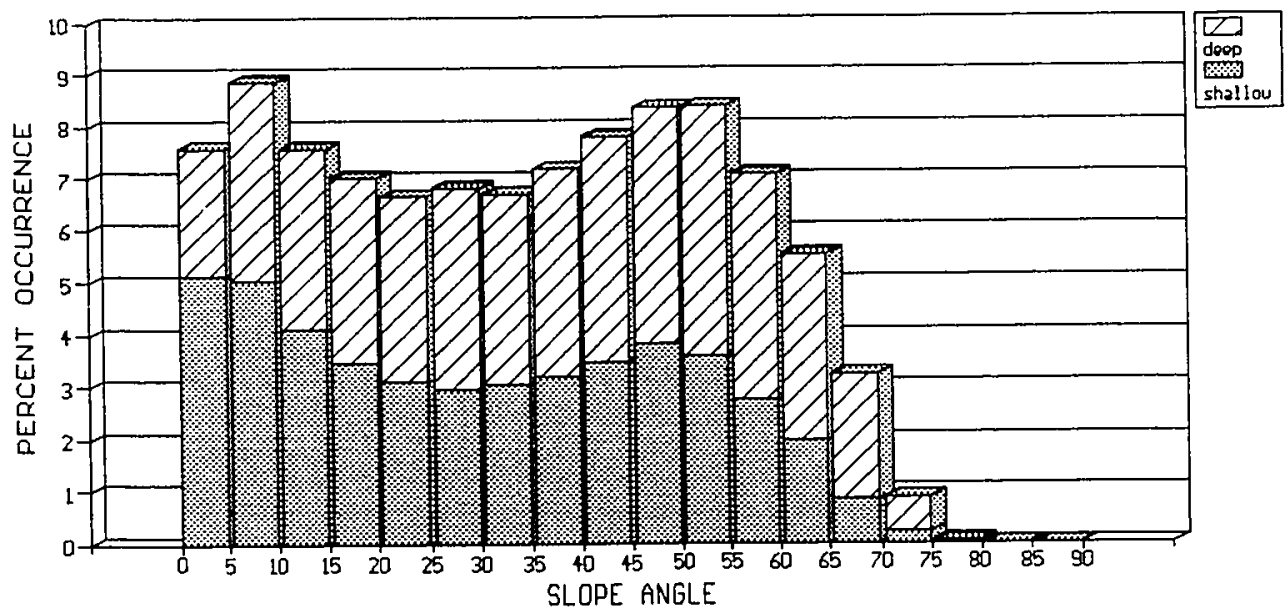

Figure 7. Distribution of shallow and deep landslides with respect to slope angle within the Arastradero lithofacies. Percent occurrence reflects percentage of all landslides.

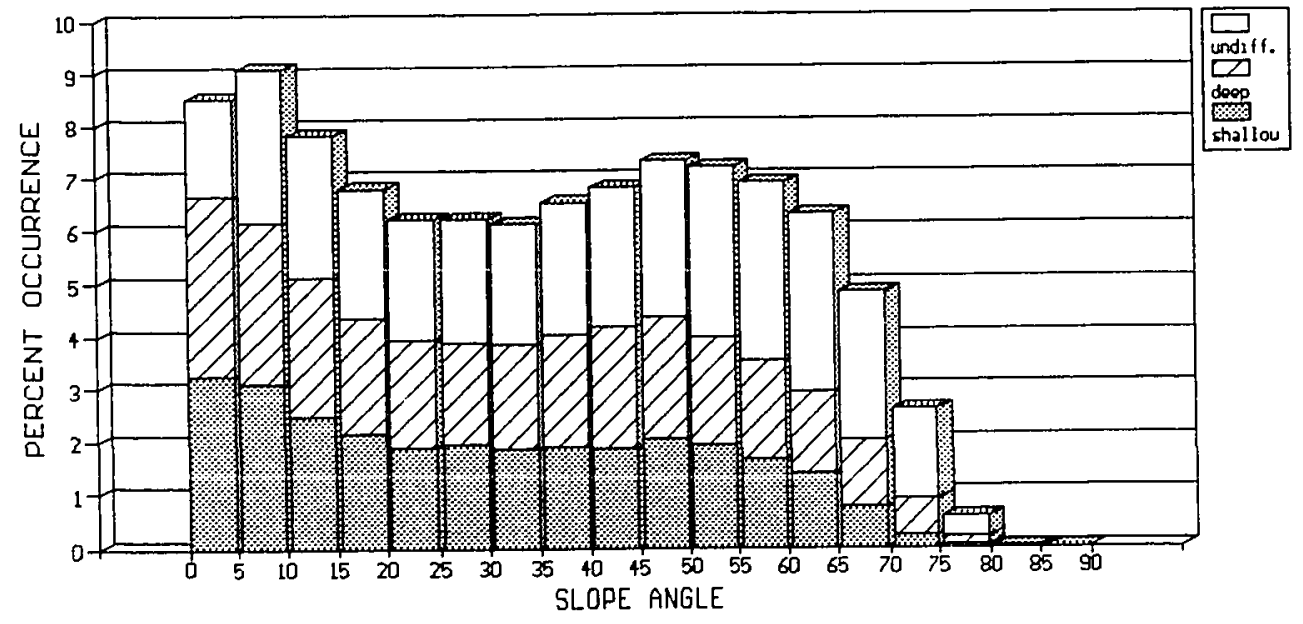

Figure 8. Distribution of shallow, deep, and undifferentiated landslides with respect to slope angle within the Stevens Creek lithofacies. Percent occurrence reflects percentage of all landslides. 


\section{Slope Aspect}

The frequency distribution of each slope-aspect octant and the percentage of each octant that has failed were determined. The distribution of slope aspect (Fig. 9) was calculated by dividing the sum of the grid nodes from each octant by the total number of grid nodes. Also included in Figure 9 is the area of each slope aspect octant that has experienced slope failure. The failed area was determined by comparing the landslide and slope aspect Boolean grids. The slope aspect grid nodes falling within the boundaries of landslides were recorded and summed. The relative abundance of shallow, deep, and undifferentiated landslides with respect to slope aspect is presented in Figure 10.

For the basis of comparison, the distribution of slope aspect in each lithofacies was determined. This was accomplished by including the Boolean geology grids in the above procedures. The frequency distribution of slope aspect for the Arastradero lithofacies is presented in Figure 11 and that for the Stevens Creek lithofacies is in Figure 12. Included in each figure is the area of each slope aspect octant that has failed. The relative abundance of shallow, deep, and undifferentiated landslides for each slope aspect octant is presented in Figure 13 for Arastradero slopes and Figure 14 for Stevens Creek slopes. 


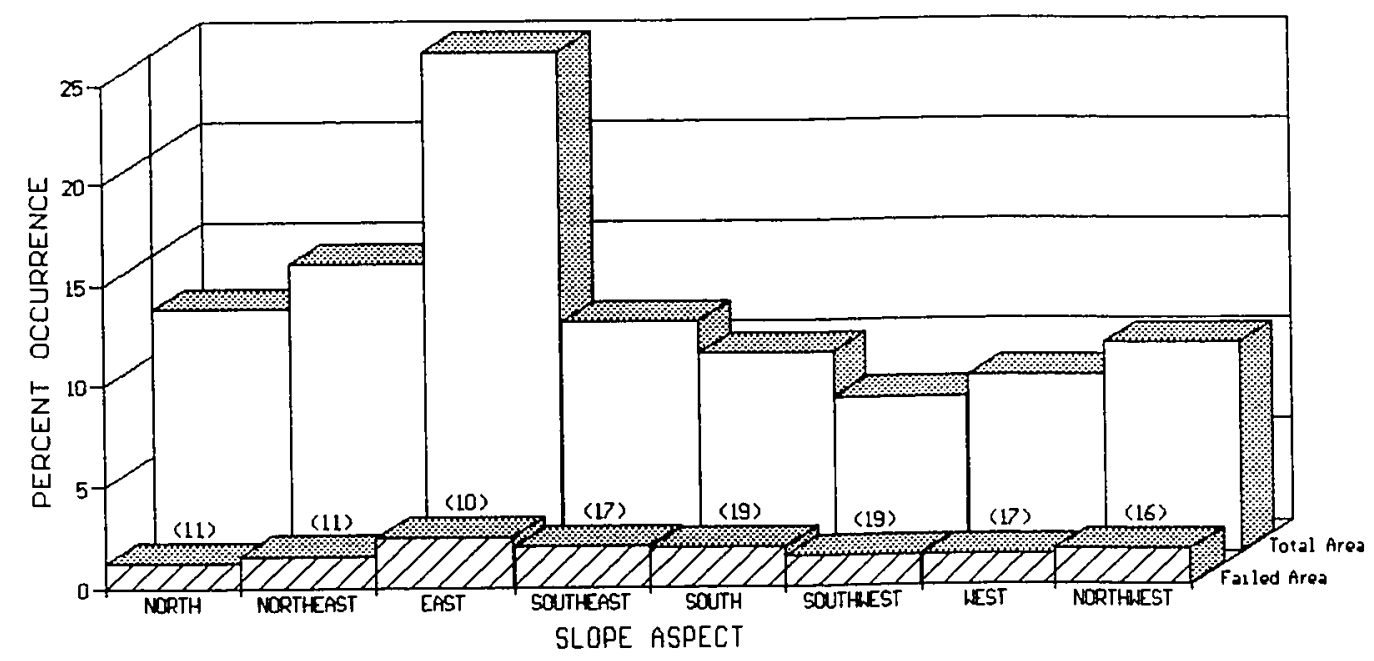

Figure 9. Distribution of slope aspect and the failed area of each slope aspect interval within the study area. Number in parentheses indicates the failed percentage of each interval.

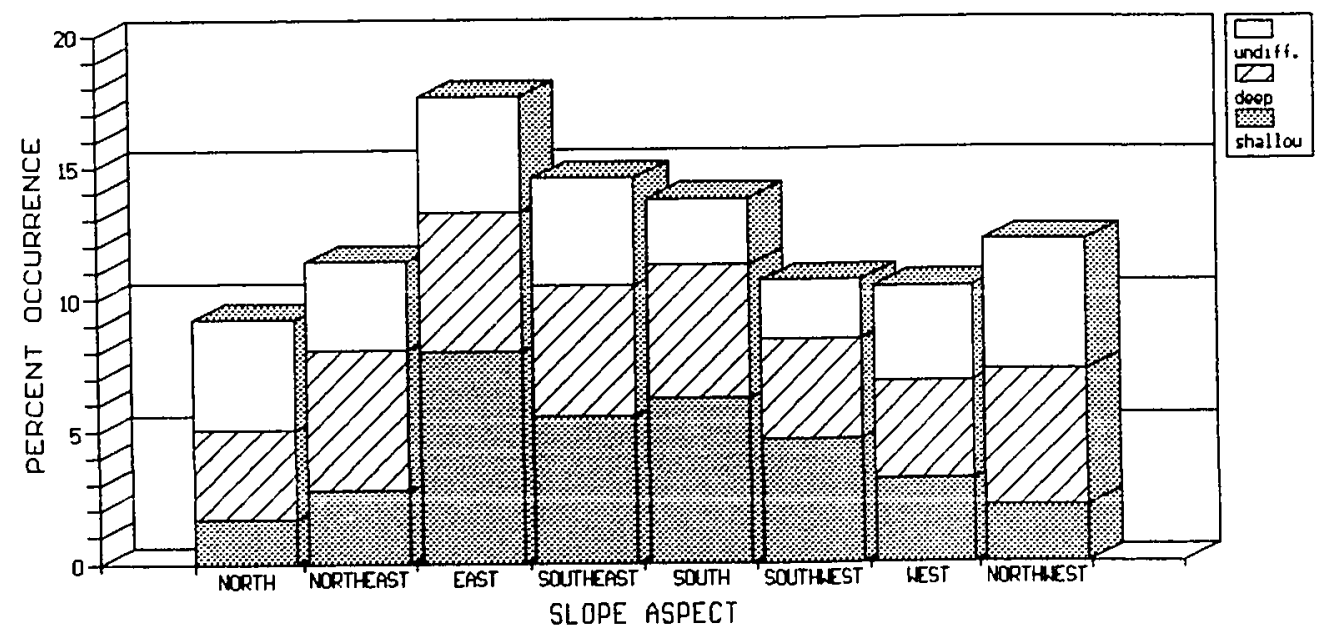

Figure 10. Distribution of shallow, deep, and undifferentiated landslides with respect to slope aspect within the study area. Percent occurrence reflects the percentage of all landslides. 


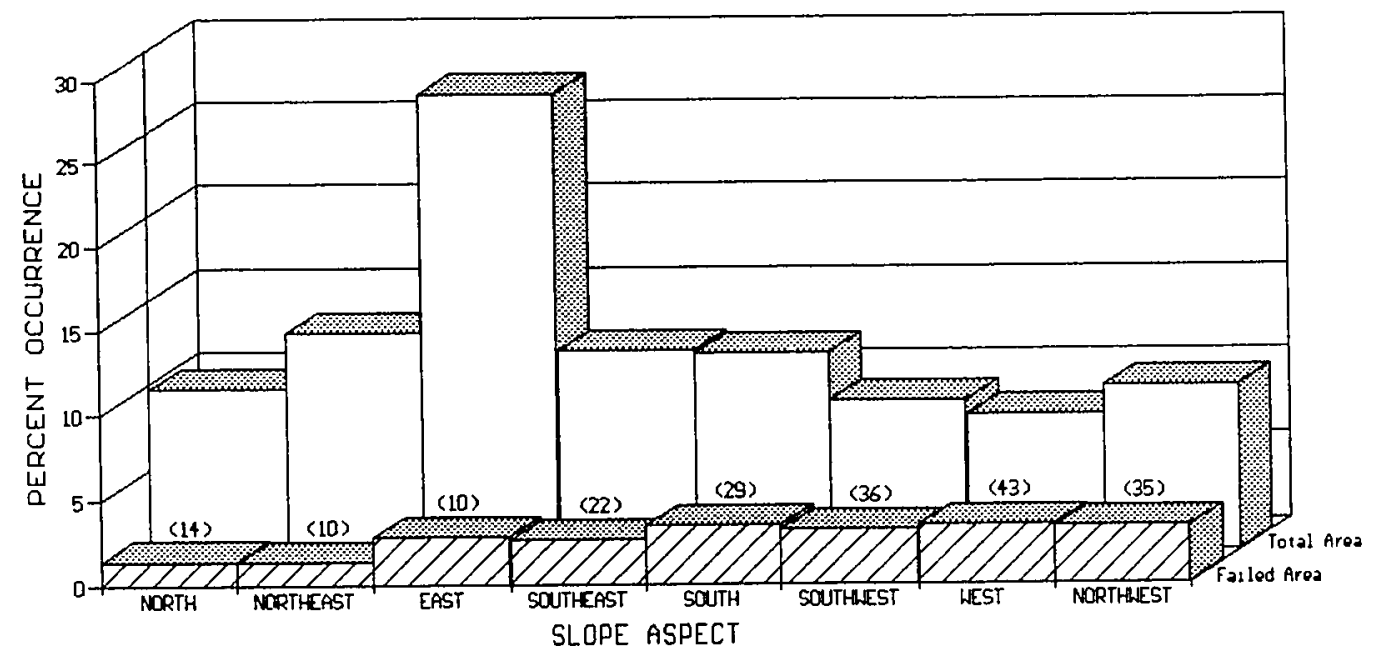

Figure 11. Distribution of slope aspect and the failed area of each slope aspect interval within the Arastradero 1ithofacies. Number in parentheses indicates the failed percentage of each interval.

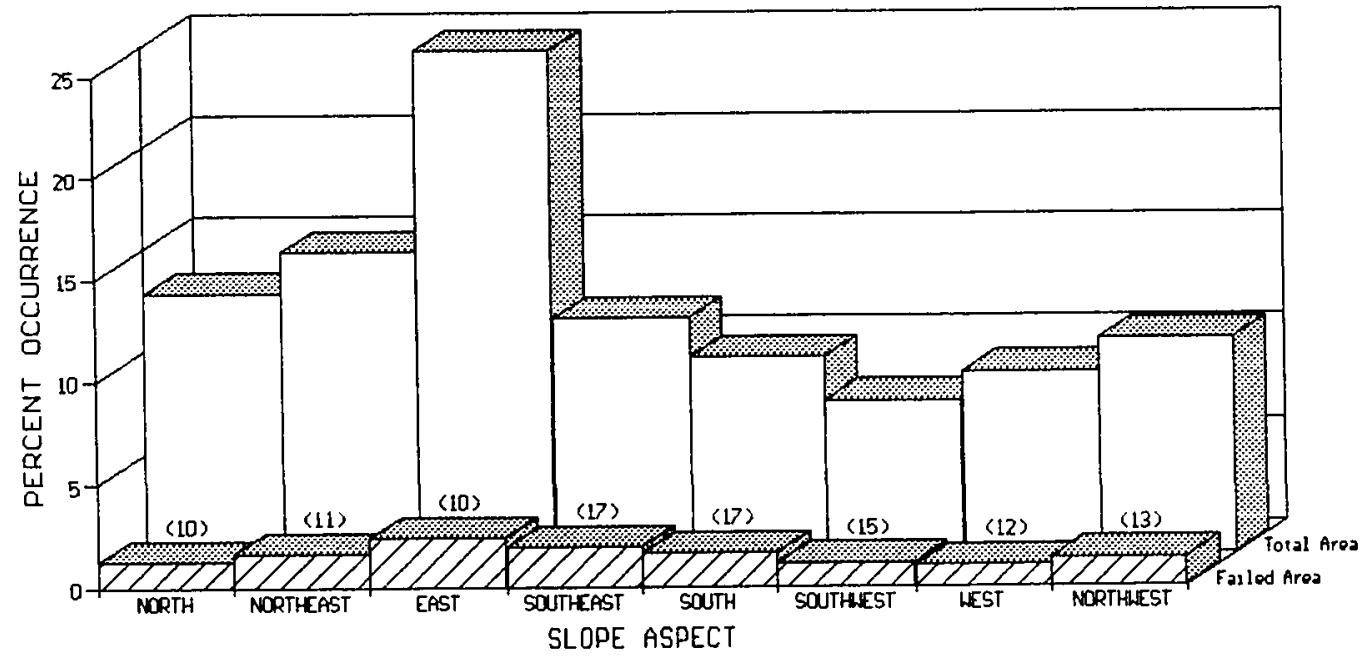

Figure 12. Distribution of slope aspect and the failed area of each slope aspect interval within the Stevens Creek lithofacies. Number in parentheses indicates the failed percentage of each interval. 


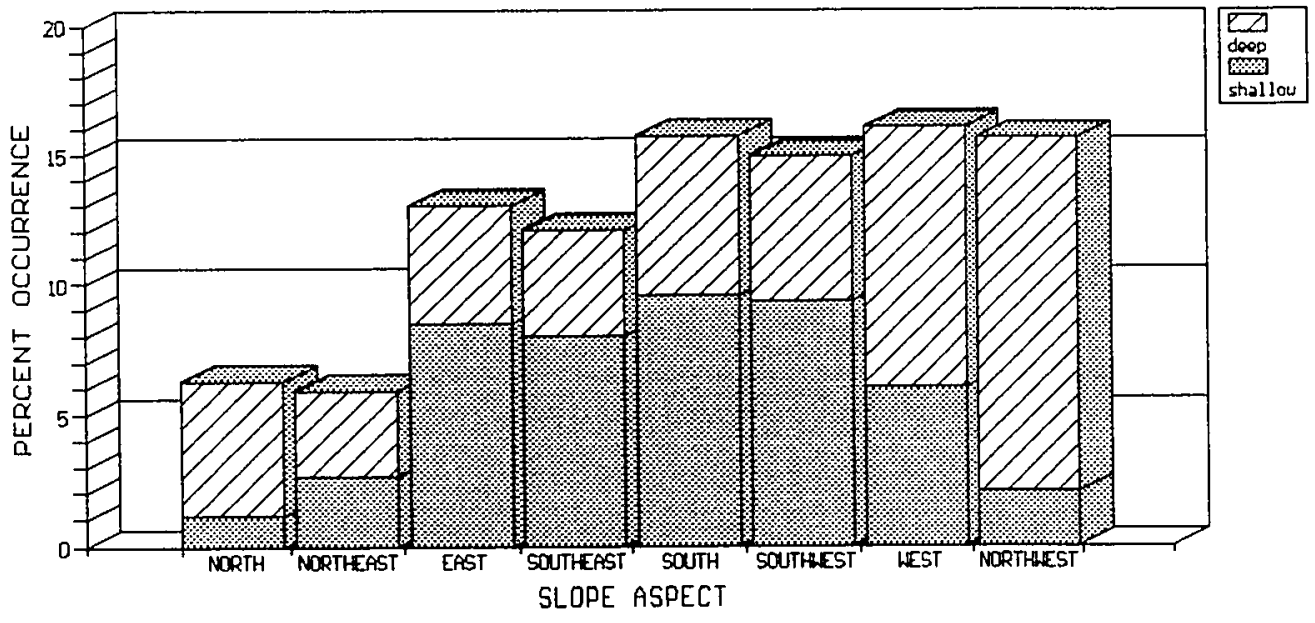

Figure 13. Distribution of shallow and deep landslides with respect to slope aspect within the Arastradero lithofacies. Percent occurrence reflects the percentage of all landslides.

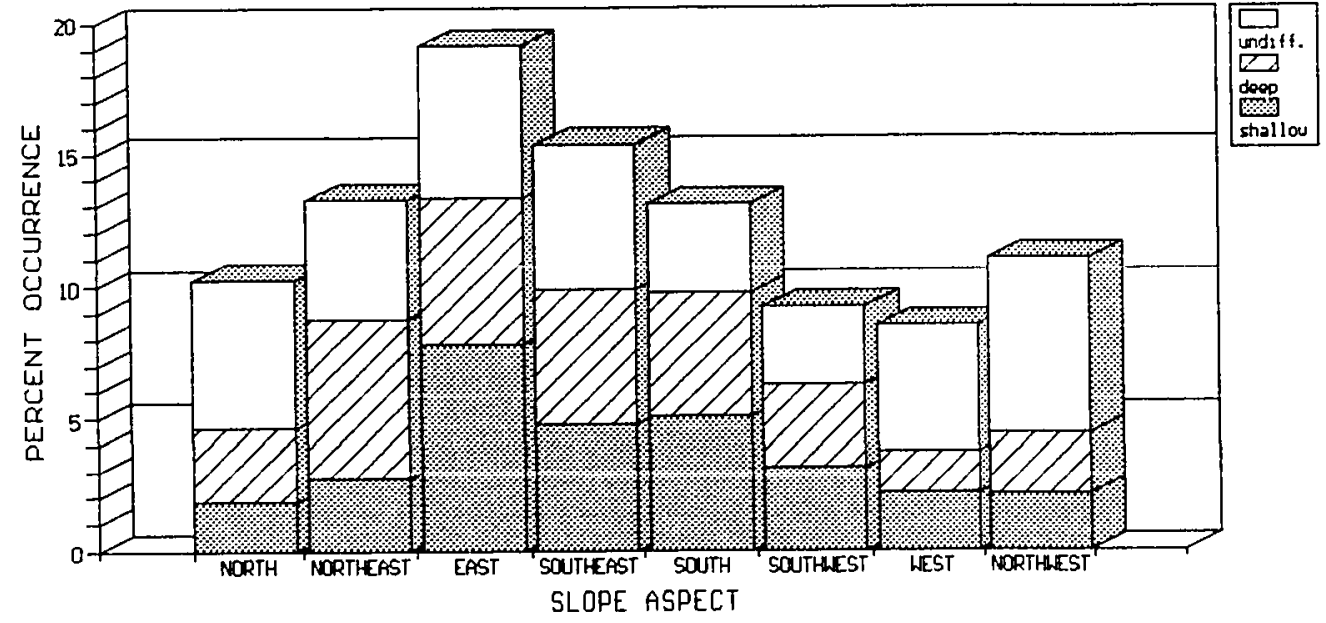

Figure 14. Distribution of shallow, deep, and undifferentiated landslides with respect to slope aspect within the stevens Creek lithofacies. Percent occurrence reflects the percentage of all landslides. 


\section{Vegetation}

The frequency distribution of the six categories of vegetation and the percentage of each category that has failed were determined. The distribution of each class of vegetation (Fig. 15) was determined by summing the grid nodes assigned to each category of vegetation and dividing by the total number of grid nodes. Also included in Figure 15 is the area of each type of vegetation that covers failed slopes. The failed area was determined by comparing the landslide and vegetation Boolean grids. The vegetation grid nodes falling within the boundaries of landslides were recorded and summed. The relative abundance of shallow, deep, and undifferentiated landslides with respect to vegetation for the study area is presented in Figure 16.

For the basis of comparison, the distribution of vegetation in each lithofacies was determined. This was accomplished by including the Boolean geology grids in the above procedures. The distribution of vegetation for the Arastradero lithofacies is presented in Figure 17 and that for the Stevens Creek lithofacies is in Figure 18. Included in each figure is the area of each type of vegetation that cover failed slopes. The relative frequency of shallow, deep, and undifferentiated landslides with respect to vegetation is presented in Figure 19 for Arastradero slopes and Figure 20 for Stevens Creek slopes. 


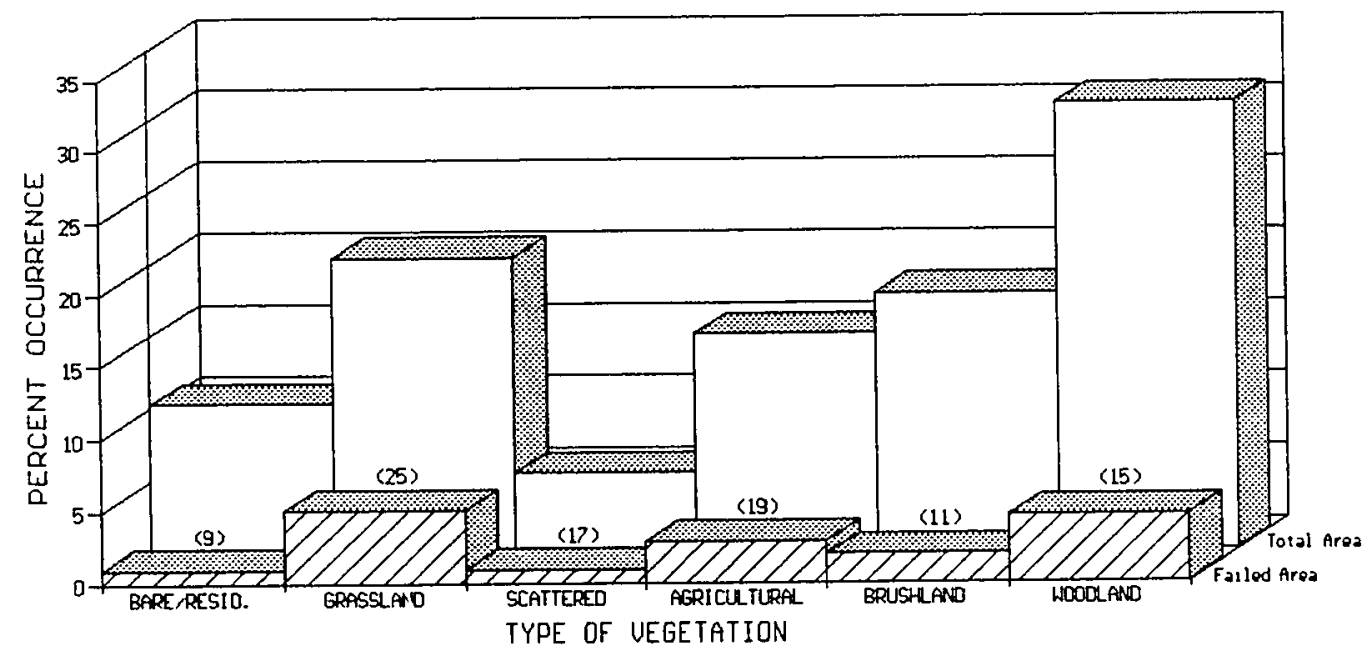

Figure 15. Distribution of vegetation and the failed area of each class of vegetation within the study area. Number in parentheses indicates the failed percentage of each class.

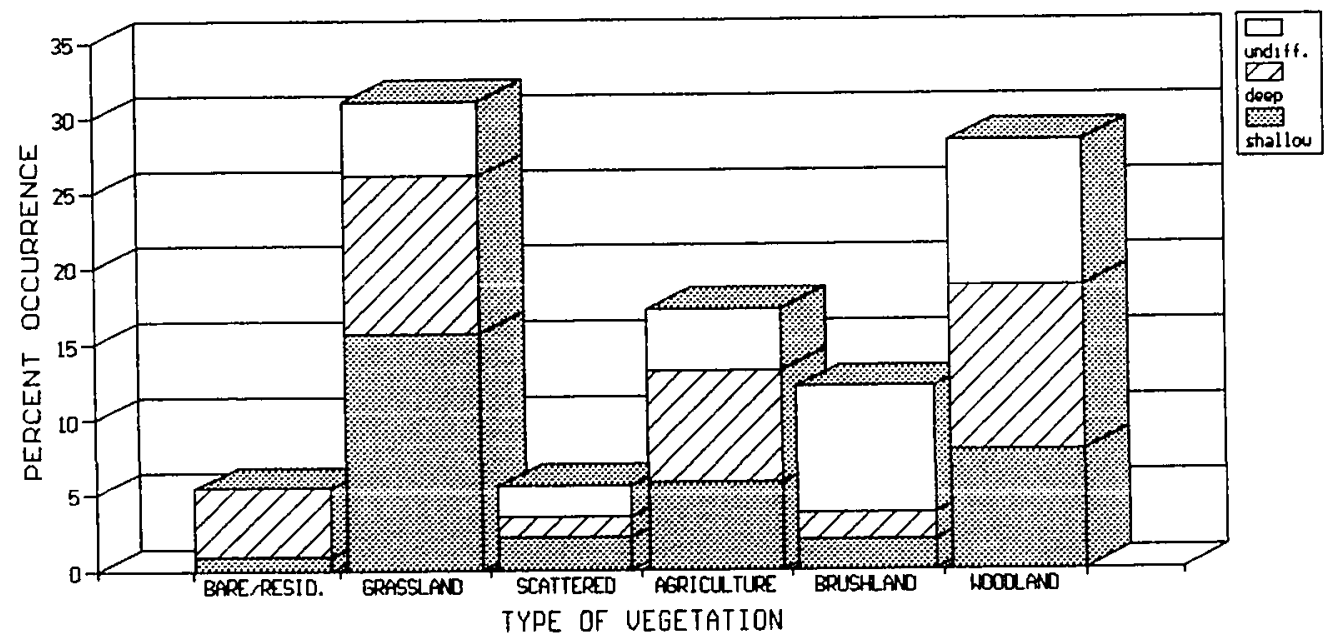

Figure 16. Distribution of shallow, deep, and undifferentiated landslides with respect to vegetation within the study area. Percent occurrence reflects the percentage of all landslides. 


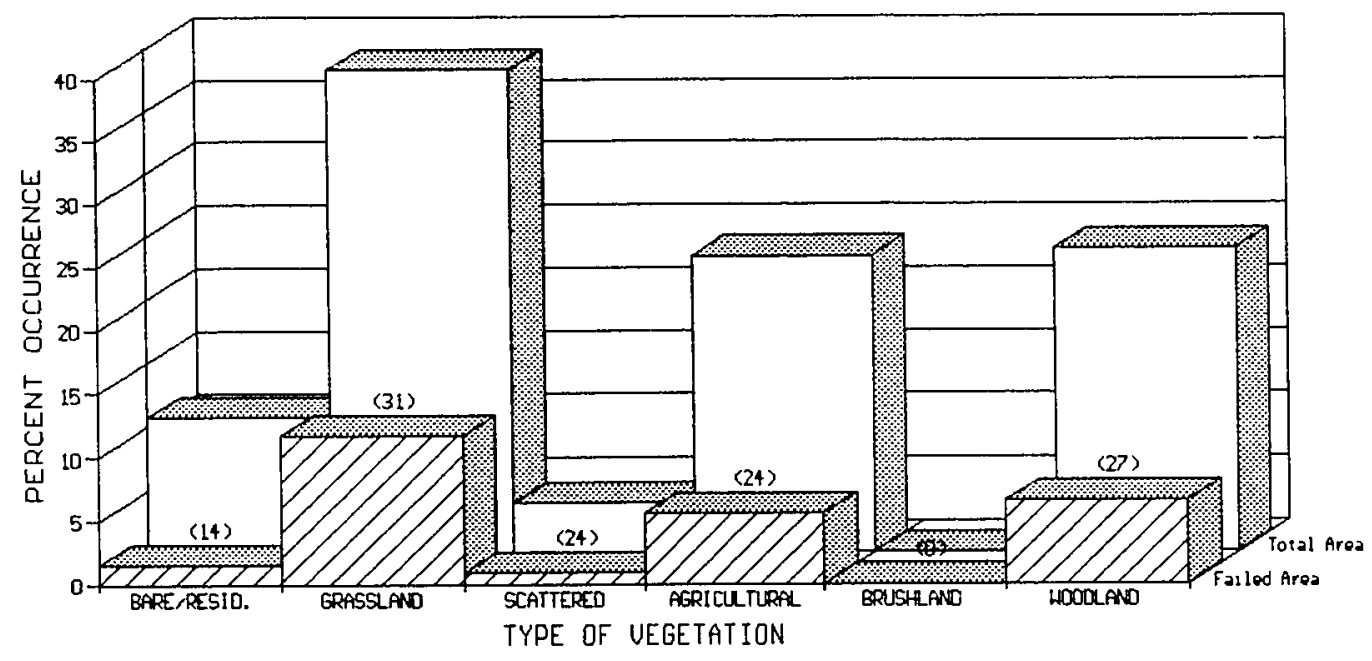

Figure 17. Distribution of vegetation and the failed area of each class of vegetation within the Arastradero lithofacies. Number in parentheses indicates the failed percentage of each class.

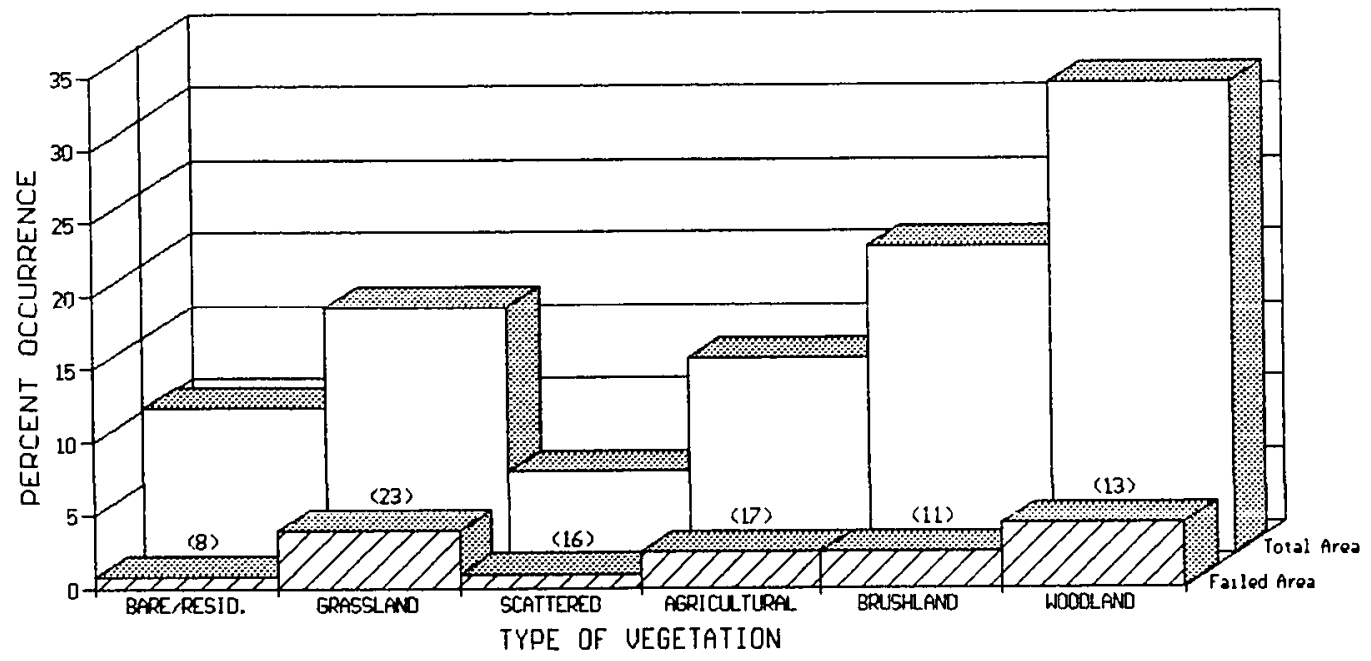

Figure 18. Distribution of vegetation and the failed area of each class of vegetation within the Stevens Creek lithofacies. Number in parentheses indicates the failed percentage of each class. 


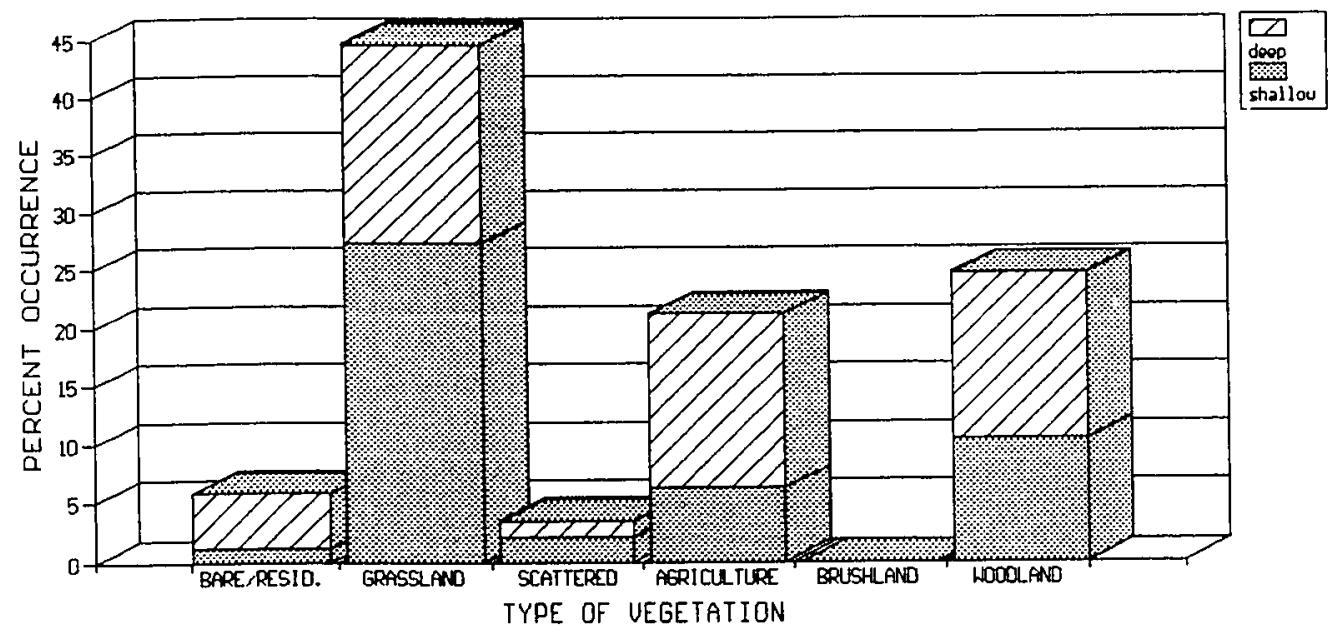

Figure 19. Distribution of shallow and deep landslides with respect to vegetation within the Arastradero lithofacies. Percent occurrence reflects the percentage of all landslides.

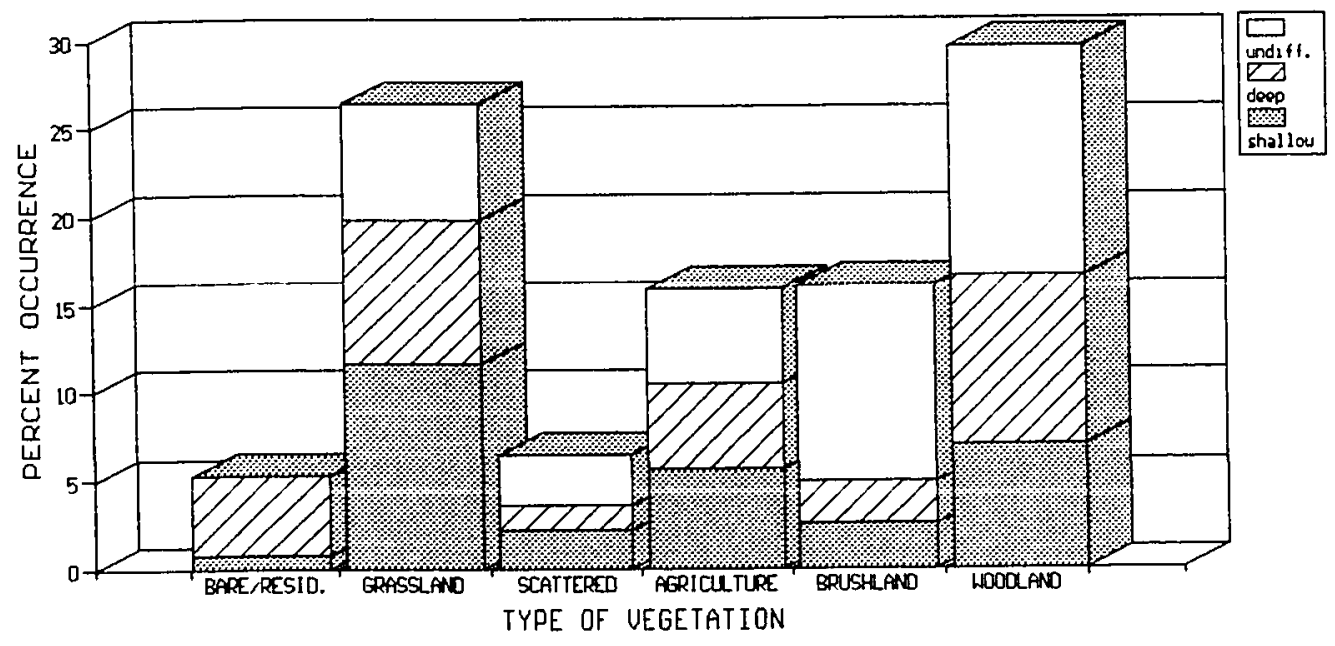

Figure 20. Distribution of shallow, deep, and undifferentiated landslides with respect to vegetation within the Stevens Creek lithofacies. Percent occurrence reflects percentage of all landslides. 


\section{Interrelationships Between Factors}

In order to interpret the complex set of factors that are responsible for causing slope failures, it is important to understand how the natural stability factors of a slope affect each other and how they combine to either increase or decrease the stability of a slope. For example, Rib and Liang (1978) reached the conclusion that, in the northern hemisphere, west-facing slopes tend to be more stable than north- and east-facing slopes because the drying effects of the afternoon sun tend to decrease the moisture content of those slopes. On the other hand, a study of landslides near Ventura, California, by Putnam and Sharp (1940) implies that the predominance of landslides on south-facing slopes was the result of the lack of vegetation on those slopes. The lack of vegetation was believed to be correlated to the lower moisture content of the slopes. It becomes apparent from these observations that interrelationships between factors and their impact on slope stability reflect a more regional phenomenon as opposed to a global one and should be investigated for each individual study area.

\section{Slope Angle and Slope Aspect}

The relationships between slope angle and slope aspect were investigated for the slopes within the study area. For this comparison, the slope angle grid was divided into six 15-degree Boolean grids, starting with $0-15^{\circ}$ and ending with 75-90\%. Fifteen-degree intervals were chosen for this 
portion of the study instead of the previously used fivedegree intervals in order to make the results more presentable. The Boolean grids of the slope angle intervals were compared to the Boolean grids of the slope aspect octants and the relationships were determined. For example, the Boolean grid for $0-15^{\circ}$ slopes was compared to the Boolean grid for north-facing slopes using the "Blogic" function of Gridzo $6.0^{\text {TM }}$ to determine how many nodes were common to both grids. This was performed for all possible combinations of slope angle and slope aspect. The distribution of slope aspect with respect to slope angle is presented in Table 1 and the distribution of slope angle with respect to slope aspect is shown in Table 2 .

The same relationships were determined for the Arastradero and Stevens Creek lithofacies. This was accomplished by including the Boolean geology grids in the above procedure. The distribution of slope aspect with respect to slope angle is presented in Table 3 for the Arastradero slopes and Table 4 for the stevens Creek slopes. Table 5 and Table 6 show the distribution of slope angle with respect to slope aspect for the Arastradero and Stevens Creek 1ithofacies, respectively.

\section{Slope Angle and Vegetation}

The relationships between slope angle and vegetation were investigated for the slopes within the study area. For this comparison, the Boolean grids of the six slope-angle 
Table 1. Distribution of slope aspect with respect to slope angle within the study area. Columns not totaling $100 \%$ result from numerical rounding.

\begin{tabular}{||c|c|c|c|c|c|c|c|c||}
\hline & $\begin{array}{c}N \\
(\%)\end{array}$ & $\begin{array}{c}\text { NE } \\
(\%)\end{array}$ & $\begin{array}{c}E \\
(\%)\end{array}$ & $\begin{array}{c}\text { SE } \\
(\%)\end{array}$ & $\begin{array}{c}\text { S } \\
(\%)\end{array}$ & $\begin{array}{c}\text { SW } \\
(\%)\end{array}$ & $\begin{array}{c}W \\
(\%)\end{array}$ & $\begin{array}{c}\text { NW } \\
(\%)\end{array}$ \\
\hline $0-15^{\circ}$ & 30 & 28 & 27 & 28 & 29 & 27 & 28 & 28 \\
$15-30^{\circ}$ & 19 & 18 & 20 & 19 & 20 & 19 & 18 & 17 \\
$30-45^{\circ}$ & 17 & 18 & 19 & 20 & 18 & 17 & 16 & 17 \\
$45-60^{\circ}$ & 19 & 20 & 20 & 21 & 19 & 19 & 19 & 22 \\
$60-75^{\circ}$ & 15 & 15 & 13 & 12 & 13 & 16 & 17 & 16 \\
$75-90^{\circ}$ & 1 & 1 & $<1$ & $<1$ & 1 & 1 & 1 & 1 \\
\hline
\end{tabular}

Table 2. Distribution of slope angle with respect to slope aspect within the study area. Columns not totaling $100 \%$ result from numerical rounding.

\begin{tabular}{||l|c|c|c|c|c|c||}
\hline N & $\begin{array}{c}0-15^{\circ} \\
(\%)\end{array}$ & $\begin{array}{c}15-30^{\circ} \\
(\%)\end{array}$ & $\begin{array}{c}30-45^{\circ} \\
(\%)\end{array}$ & $\begin{array}{c}45-60^{\circ} \\
(\%)\end{array}$ & $\begin{array}{c}60-75^{\circ} \\
(\%)\end{array}$ & $\begin{array}{c}75-90^{\circ} \\
(\%)\end{array}$ \\
\hline $\mathrm{NE}$ & 15 & 14 & 13 & 13 & 14 & 16 \\
$\mathrm{E}$ & 16 & 16 & 16 & 16 & 17 & 20 \\
$\mathrm{SE}$ & 13 & 13 & 18 & 17 & 15 & 12 \\
$\mathrm{~S}$ & 12 & 11 & 11 & 13 & 11 & 4 \\
$\mathrm{SW}$ & 9 & 8 & 8 & 8 & 10 & 10 \\
$\mathrm{~W}$ & 10 & 9 & 9 & 9 & 11 & 13 \\
$\mathrm{NW}$ & 11 & 10 & 11 & 12 & 13 & 10 \\
\hline
\end{tabular}


Table 3. Distribution of slope aspect with respect to slope angle within the Arastradero lithofacies. Columns not totaling $100 \%$ result from numerical rounding.

\begin{tabular}{|c|c|c|c|c|c|c|c|c||}
\hline & $\begin{array}{c}N \\
(\%)\end{array}$ & $\begin{array}{c}\text { NE } \\
(\%)\end{array}$ & $\begin{array}{c}E \\
(\%)\end{array}$ & $\begin{array}{c}S E \\
(\%)\end{array}$ & $\begin{array}{c}S \\
(\%)\end{array}$ & $\begin{array}{c}S W \\
(\%)\end{array}$ & $\begin{array}{c}W \\
(\%)\end{array}$ & $\begin{array}{c}N W \\
(\%)\end{array}$ \\
\hline $0-15^{\circ}$ & 31 & 24 & 24 & 29 & 32 & 33 & 31 & 25 \\
$15-30^{\circ}$ & 23 & 20 & 22 & 21 & 20 & 19 & 20 & 18 \\
$30-45^{\circ}$ & 21 & 20 & 22 & 23 & 19 & 18 & 18 & 21 \\
$45-60^{\circ}$ & 18 & 23 & 22 & 21 & 21 & 21 & 21 & 25 \\
$60-75^{\circ}$ & 8 & 12 & 9 & 5 & 8 & 10 & 10 & 11 \\
$75-90^{\circ}$ & $<1$ & $<1$ & $<1$ & $<1$ & $<1$ & $<1$ & $<1$ & $<1$ \\
\hline
\end{tabular}

Table 4. Distribution of slope aspect with respect to slope angle within the Stevens Creek lithofacies. Columns not totaling $100 \%$ result from numerical rounding.

\begin{tabular}{||c|c|c|c|c|c|c|c|c||}
\hline & $\begin{array}{c}\mathrm{N} \\
(\%)\end{array}$ & $\begin{array}{c}\mathrm{NE} \\
(\%)\end{array}$ & $\begin{array}{c}\mathrm{E} \\
\left(\frac{\circ}{6}\right)\end{array}$ & $\begin{array}{c}\mathrm{SE} \\
\left(\frac{\circ}{6}\right)\end{array}$ & $\begin{array}{c}\mathrm{S} \\
\left(\frac{\%}{\circ}\right)\end{array}$ & $\begin{array}{c}\mathrm{SW} \\
(\%)\end{array}$ & $\begin{array}{c}\mathrm{W} \\
(\%)\end{array}$ & $\begin{array}{c}\mathrm{NW} \\
(\%)\end{array}$ \\
\hline $0-15^{\circ}$ & 30 & 29 & 28 & 28 & 29 & 26 & 28 & 28 \\
$15-30^{\circ}$ & 18 & 18 & 20 & 19 & 19 & 18 & 18 & 17 \\
$30-45^{\circ}$ & 16 & 17 & 18 & 19 & 18 & 17 & 16 & 16 \\
$45-60^{\circ}$ & 19 & 20 & 19 & 21 & 19 & 19 & 19 & 21 \\
$60-75^{\circ}$ & 16 & 15 & 13 & 13 & 15 & 18 & 18 & 17 \\
$75-90^{\circ}$ & 1 & 1 & 1 & $<1$ & 1 & 2 & 1 & 1 \\
\hline
\end{tabular}


Table 5. Distribution of slope angle with respect to slope aspect within the Arastradero lithofacies. Columns not totaling $100 \%$ result from numerical rounding.

\begin{tabular}{||l|c|c|c|c|c|c||}
\hline \hline & $\begin{array}{c}0-15^{\circ} \\
\left(\frac{\circ}{6}\right)\end{array}$ & $\begin{array}{c}15-30^{\circ} \\
\left(\frac{\circ}{6}\right)\end{array}$ & $\begin{array}{c}30-45^{\circ} \\
\left(\frac{\circ}{6}\right)\end{array}$ & $\begin{array}{c}45-60^{\circ} \\
\left(\frac{\circ}{6}\right)\end{array}$ & $\begin{array}{c}60-75^{\circ} \\
\left(\frac{\circ}{6}\right)\end{array}$ & $\begin{array}{c}75-90^{\circ} \\
\left(\frac{\circ}{6}\right)\end{array}$ \\
\hline $\mathrm{N}$ & 12 & 12 & 11 & 9 & 10 & 20 \\
$\mathrm{NE}$ & 13 & 15 & 15 & 16 & 20 & 35 \\
$\mathrm{E}$ & 15 & 18 & 18 & 18 & 17 & 16 \\
$\mathrm{SE}$ & 14 & 14 & 15 & 13 & 8 & 5 \\
$\mathrm{~S}$ & 15 & 13 & 13 & 13 & 11 & 8 \\
$\mathrm{SW}$ & 12 & 9 & 9 & 10 & 11 & 7 \\
$\mathrm{~W}$ & 10 & 9 & 8 & 9 & 10 & 4 \\
$\mathrm{NW}$ & 10 & 9 & 11 & 12 & 13 & 5 \\
\hline
\end{tabular}

Table 6. Distribution of slope angle with respect to slope aspect within the Stevens Creek lithofacies. Columns not totaling $100 \%$ result from numerical rounding.

\begin{tabular}{||l|c|c|c|c|c|c||}
\hline \hline N & $\begin{array}{c}0-15^{\circ} \\
(\%)\end{array}$ & $\begin{array}{c}15-30^{\circ} \\
(\%)\end{array}$ & $\begin{array}{c}30-45^{\circ} \\
(\%)\end{array}$ & $\begin{array}{c}45-60^{\circ} \\
(\%)\end{array}$ & $\begin{array}{c}60-75^{\circ} \\
(\%)\end{array}$ & $\begin{array}{c}75-90^{\circ} \\
(\%)\end{array}$ \\
$\mathrm{NE}$ & 17 & 14 & 14 & 14 & 15 & 15 \\
$\mathrm{E}$ & 17 & 16 & 16 & 16 & 16 & 17 \\
$\mathrm{SE}$ & 12 & 13 & 18 & 17 & 15 & 11 \\
$\mathrm{~S}$ & 11 & 11 & 11 & 13 & 11 & 4 \\
$\mathrm{SW}$ & 8 & 8 & 8 & 8 & 10 & 10 \\
$\mathrm{~W}$ & 10 & 9 & 9 & 9 & 11 & 15 \\
$\mathrm{NW}$ & 11 & 10 & 11 & 12 & 13 & 11 \\
\hline
\end{tabular}


intervals were compared to the six Boolean grids of vegetation and the relationships were determined. For example, the Boolean grid for $0-15^{\circ}$ slopes was compared to the Boolean grid for bare/residential slopes using the "Blogic" function of Gridzo 6. $0^{\text {TM }}$ to determine how many nodes were common to both grids. This was performed for all possible combinations of slope angle and vegetation. The distribution of slope angle with respect to vegetation is presented in Table 7 and the distribution of vegetation with respect to slope angle is shown in Table 8 .

The same relationships were determined for the Arastradero and Stevens Creek lithofacies. This was accomplished by including the Boolean geology grids in the above procedures. The distribution of slope angle with respect to vegetation is presented in Table 9 for the Arastradero slopes and Table 10 for the Stevens Creek slopes. Table 11 and Table 12 show the distribution of vegetation with respect to slope angle for the Arastradero and Stevens Creek lithofacies, respectively.

\section{Slope Aspect and Vegetation}

The relationships between slope aspect and vegetation

were investigated for the slopes within the study area. For this comparison, the Boolean grids of the slope aspect octants were compared to the six Boolean grids of vegetation and the relationships were determined. For example the Boolean grid for north-facing slopes was compared to the 
Table 7. Distribution of slope angle with respect to vegetation within the study area. Columns not totaling $100 \%$ result from numerical rounding.

\begin{tabular}{||l|c|c|c|c|c|c||}
\hline & $\begin{array}{c}0-15 \\
(\%)\end{array}$ & $\begin{array}{c}15-30 \\
(\%)\end{array}$ & $\begin{array}{c}30-45 \\
(\%)\end{array}$ & $\begin{array}{c}45-60 \\
(\%)\end{array}$ & $\begin{array}{c}60-75 \\
(\%)\end{array}$ & $\begin{array}{c}75-90 \\
(\%)\end{array}$ \\
\hline Bare & 12 & 11 & 11 & 9 & 7 & 9 \\
Scatter & 5 & 21 & 20 & 19 & 14 & 8 \\
Agland & 17 & 16 & 16 & 15 & 12 & 5 \\
Brush & 13 & 17 & 17 & 20 & 27 & 34 \\
Wood & 28 & 30 & 31 & 32 & 35 & 37 \\
\hline
\end{tabular}

Table 8. Distribution of vegetation with respect to slope angle within the study area. Columns not totaling $100 \%$ result from numerical rounding.

\begin{tabular}{||c|c|c|c|c|c|c||}
\hline & $\begin{array}{c}\text { Bare } \\
\left(\frac{\circ}{6}\right)\end{array}$ & $\begin{array}{c}\text { Grass } \\
(\%)\end{array}$ & $\begin{array}{c}\text { Scatter } \\
\left(\frac{\circ}{6}\right)\end{array}$ & $\begin{array}{c}\text { Agland } \\
(\%)\end{array}$ & $\begin{array}{c}\text { Brush } \\
\left(\frac{\circ}{6}\right)\end{array}$ & $\begin{array}{c}\text { Wood } \\
\left(\frac{\circ}{6}\right)\end{array}$ \\
\hline $0-15^{\circ}$ & 30 & 31 & 20 & 28 & 17 & 22 \\
$15-30^{\circ}$ & 21 & 20 & 18 & 20 & 18 & 19 \\
$30-45^{\circ}$ & 20 & 19 & 20 & 20 & 17 & 19 \\
$45-60^{\circ}$ & 18 & 20 & 24 & 21 & 22 & 22 \\
$60-75^{\circ}$ & 10 & 10 & 18 & 11 & 25 & 17 \\
$75-90^{\circ}$ & 1 & $<1$ & 1 & $<1$ & 2 & 1 \\
\hline
\end{tabular}


Table 9. Distribution of slope angle with respect to vegetation for slopes within the Arastradero lithofacies. Columns not totaling $100 \%$ result from numerical rounding.

\begin{tabular}{||l|c|c|c|c|c|c||}
\hline & $\begin{array}{c}0-15 \\
(\%)\end{array}$ & $\begin{array}{c}15-30 \\
(\%)\end{array}$ & $\begin{array}{c}30-45 \\
(\%)\end{array}$ & $\begin{array}{c}45-60 \\
(\%)\end{array}$ & $\begin{array}{c}60-75 \\
(\%)\end{array}$ & $\begin{array}{c}75-90 \\
(\%)\end{array}$ \\
\hline Bare & 9 & 11 & 12 & 13 & 11 & 6 \\
Scatter & 52 & 41 & 39 & 36 & 30 & 15 \\
Agland & 23 & 24 & 25 & 26 & 26 & 13 \\
Brush & 0 & 0 & 0 & 0 & 0 & 0 \\
wood & 21 & 21 & 20 & 23 & 31 & 54 \\
\hline
\end{tabular}

Table 10. Distribution of slope angle with respect to vegetation for slopes within the Stevens Creek lithofacies. columns not totaling $100 \%$ result from numerical rounding.

\begin{tabular}{|l|c|c|c|c|c|c||}
\hline & $\begin{array}{c}0-15 \\
\left(\frac{\circ}{6}\right)\end{array}$ & $\begin{array}{c}15-30 \\
(\%)\end{array}$ & $\begin{array}{c}30-45 \\
\left(\frac{\circ}{6}\right)\end{array}$ & $\begin{array}{c}45-60 \\
(\%)\end{array}$ & $\begin{array}{c}60-75 \\
(\%)\end{array}$ & $\begin{array}{c}75-90 \\
(\%)\end{array}$ \\
\hline Bare & 13 & 11 & 10 & 8 & 6 & 9 \\
Scatter & 22 & 17 & 16 & 15 & 11 & 7 \\
Agland & 16 & 14 & 14 & 13 & 10 & 4 \\
Brush & 15 & 20 & 20 & 23 & 32 & 40 \\
Wood & 29 & 32 & 33 & 34 & 36 & 34 \\
\hline
\end{tabular}


Table 11. Distribution of vegetation with respect to slope angle for slopes within the Arastradero lithofacies. Columns not totaling $100 \%$ result from numerical rounding.

\begin{tabular}{|c|c|c|c|c|c|c||}
\hline & $\begin{array}{c}\text { Bare } \\
(\%)\end{array}$ & $\begin{array}{c}\text { Grass } \\
(\%)\end{array}$ & $\begin{array}{c}\text { Scatter } \\
(\%)\end{array}$ & $\begin{array}{c}\text { Agland } \\
(\%)\end{array}$ & $\begin{array}{c}\text { Brush } \\
(\%)\end{array}$ & $\begin{array}{c}\text { Wood } \\
(\%)\end{array}$ \\
\hline $0-15^{\circ}$ & 22 & 30 & 34 & 25 & 0 & 26 \\
$15-30^{\circ}$ & 21 & 22 & 20 & 20 & 0 & 20 \\
$30-45^{\circ}$ & 24 & 21 & 20 & 21 & 0 & 19 \\
$45-60^{\circ}$ & 26 & 21 & 18 & 24 & 0 & 23 \\
$60-75^{\circ}$ & 8 & 6 & 7 & 9 & 0 & 12 \\
$75-90^{\circ}$ & $<1$ & $<1$ & $<1$ & $<1$ & 0 & $<1$ \\
\hline
\end{tabular}

Table 12. Distribution of vegetation with respect to slope angle for slopes within the Stevens Creek lithofacies. Columns not totaling $100 \%$ result from numerical rounding.

\begin{tabular}{||c|c|c|c|c|c|c|}
\hline & $\begin{array}{c}\text { Bare } \\
(\%)\end{array}$ & $\begin{array}{c}\text { Grass } \\
(\%)\end{array}$ & $\begin{array}{c}\text { Scatter } \\
(\%)\end{array}$ & $\begin{array}{c}\text { Agland } \\
(\%)\end{array}$ & $\begin{array}{c}\text { Brush } \\
(\%)\end{array}$ & $\begin{array}{c}\text { Wood } \\
(\%)\end{array}$ \\
\hline $0-15^{\circ}$ & 32 & 31 & 18 & 29 & 17 & 21 \\
$15-30^{\circ}$ & 22 & 19 & 17 & 20 & 18 & 19 \\
$30-45^{\circ}$ & 19 & 18 & 20 & 19 & 17 & 19 \\
$45-60^{\circ}$ & 17 & 20 & 24 & 20 & 22 & 22 \\
$60-75^{\circ}$ & 10 & 11 & 19 & 12 & 25 & 18 \\
$75-90^{\circ}$ & 1 & $<1$ & 1 & $<1$ & 2 & 1 \\
\hline
\end{tabular}


Boolean grid for bare/residential slopes using the "Blogic" function of Gridzo $6.0^{\mathrm{m}}$ to determine how many nodes were common to both grids. This was performed for all possible combinations of slope aspect and vegetation. The distribution of slope aspect with respect to vegetation is presented in Table 13 and the distribution of vegetation with respect to slope aspect is shown in Table 14.

The same relationships were determined for the Arastradero and Stevens Creek Iithofacies. This was accomplished. by including the Boolean geology grids in the above procedures. The distribution of slope aspect with respect to vegetation is presented in Table 15 for the Arastradero slopes and Table 16 for the Stevens Creek slopes. Table 17 and Table 18 show the distribution of vegetation with respect to slope aspect for the Arastradero and Stevens Creek lithofacies, respectively.

\section{Interpretation of Results}

\section{Slope Angle and Landslides}

The degree of slope within the study area exhibits a bimodal distribution (Fig. 3). Both lithofacies have similar distributions, with primary modal occurrences of $11 \%$ at the $5-10^{\circ}$ interval (Figs. 5 and 6 ). Secondary modes are present at the 45-50' interval of the Arastradero slopes $(8 \%)$ and the $55-60^{\circ}$ interval of stevens Creek slopes $(7 \%)$. Overall, slopes steeper than $45^{\circ}$ are $5 \%$ more abundant in the Stevens Creek Iithofacies than in the Arastradero litho- 
Table 13. Distribution of slope aspect with respect to vegetation for slopes within the study area. Columns not totaling $100 \%$ result from numerical rounding.

\begin{tabular}{||l|c|c|c|c|c|c|c|c||}
\hline & $\begin{array}{c}\mathrm{N} \\
(\%)\end{array}$ & $\begin{array}{c}\mathrm{NE} \\
(\%)\end{array}$ & $\begin{array}{c}\mathrm{E} \\
(\%)\end{array}$ & $\begin{array}{c}\mathrm{SE} \\
(\%)\end{array}$ & $\begin{array}{c}\mathrm{S} \\
(\%)\end{array}$ & $\begin{array}{c}\text { SW } \\
(\%)\end{array}$ & $\begin{array}{c}\text { W } \\
(\%)\end{array}$ & $\begin{array}{c}\text { NW } \\
(\%)\end{array}$ \\
\hline Bare & 10 & 13 & 12 & 12 & 10 & 8 & 6 & 8 \\
Grass & 16 & 16 & 23 & 25 & 25 & 22 & 18 & 16 \\
Scatter & 5 & 4 & 5 & 7 & 9 & 7 & 4 & 4 \\
Agland & 16 & 17 & 15 & 15 & 13 & 11 & 14 & 19 \\
Brush & 13 & 14 & 15 & 17 & 21 & 29 & 27 & 17 \\
Wood & 41 & 36 & 30 & 24 & 22 & 22 & 31 & 38 \\
\hline
\end{tabular}

Table 14. Distribution of vegetation with respect to slope aspect for slopes within the study area. Columns not totaling $100 \%$ result from numerical rounding.

\begin{tabular}{||l|c|c|c|c|c|c||}
\hline & $\begin{array}{c}\text { Bare } \\
(\%)\end{array}$ & $\begin{array}{c}\text { Grass } \\
(\%)\end{array}$ & $\begin{array}{c}\text { Scatter } \\
(\%)\end{array}$ & $\begin{array}{c}\text { Agland } \\
(\%)\end{array}$ & $\begin{array}{c}\text { Brush } \\
(\%)\end{array}$ & $\begin{array}{c}\text { Wood } \\
(\%)\end{array}$ \\
\hline $\mathrm{N}$ & 11 & 9 & 11 & 13 & 9 & 17 \\
$\mathrm{NE}$ & 19 & 11 & 12 & 17 & 11 & 17 \\
$\mathrm{E}$ & 25 & 25 & 18 & 20 & 18 & 20 \\
$\mathrm{SE}$ & 14 & 15 & 17 & 13 & 12 & 10 \\
$\mathrm{~S}$ & 11 & 14 & 17 & 9 & 12 & 8 \\
$\mathrm{SW}$ & 7 & 9 & 11 & 7 & 13 & 6 \\
$\mathrm{~W}$ & 5 & 9 & 7 & 9 & 14 & 9 \\
$\mathrm{NW}$ & 8 & 8 & 7 & 13 & 10 & 13 \\
\hline \hline
\end{tabular}


Table 15. Distribution of slope aspect with respect to vegetation for slopes within the Arastradero lithofacies. Columns not totaling $100 \%$ result from numerical rounding.

\begin{tabular}{|c|c|c|c|c|c|c|c|c|}
\hline & $\begin{array}{c}N \\
\left(\frac{0}{6}\right)\end{array}$ & $\begin{array}{l}\mathrm{NE} \\
\left(\frac{\circ}{6}\right)\end{array}$ & $\begin{array}{c}E \\
\left(\frac{o}{b}\right)\end{array}$ & $\begin{array}{l}\mathrm{SE} \\
\left(\frac{o}{6}\right)\end{array}$ & $\underset{(\%)}{S}$ & $\begin{array}{l}\text { SW } \\
\left(\frac{\circ}{6}\right)\end{array}$ & $\begin{array}{c}W \\
\left(\frac{\circ}{6}\right)\end{array}$ & $\begin{array}{l}N W \\
\left(\frac{\%}{6}\right)\end{array}$ \\
\hline Bare & 2 & 7 & 11 & 23 & 22 & 11 & 3 & 1 \\
\hline Grass & 34 & 34 & 35 & 38 & 41 & 50 & 43 & 34 \\
\hline scatter & 4 & 5 & 5 & 4 & 3 & 2 & 3 & 2 \\
\hline Agland & 33 & 27 & 14 & 14 & 18 & 26 & 29 & 38 \\
\hline Brush & 0 & 0 & 0 & 0 & 0 & 0 & 0 & 0 \\
\hline Wood & 26 & 27 & 35 & 20 & 17 & 11 & 22 & 24 \\
\hline
\end{tabular}

Table 16. Distribution of slope aspect with respect to vegetation for slopes within the Stevens Creek lithofacies. Columns not totaling $100 \%$ result from numerical rounding.

\begin{tabular}{||l|c|c|c|c|c|c|c|c||}
\hline & $\begin{array}{c}\mathrm{N} \\
\left(\frac{\circ}{6}\right)\end{array}$ & $\begin{array}{c}\mathrm{NE} \\
(\%)\end{array}$ & $\begin{array}{c}\mathrm{E} \\
\left(\frac{\circ}{6}\right)\end{array}$ & $\begin{array}{c}\mathrm{SE} \\
\left(\frac{\circ}{6}\right)\end{array}$ & $\begin{array}{c}\mathrm{S} \\
\left(\frac{\circ}{6}\right)\end{array}$ & $\begin{array}{c}\mathrm{SW} \\
\left(\frac{\%}{6}\right)\end{array}$ & $\begin{array}{c}W \\
(\%)\end{array}$ & $\begin{array}{c}\mathrm{NW} \\
\left(\frac{\circ}{6}\right)\end{array}$ \\
\hline Bare & 11 & 14 & 13 & 10 & 8 & 7 & 6 & 9 \\
Grass & 13 & 13 & 21 & 23 & 22 & 17 & 14 & 12 \\
Scatter & 5 & 4 & 5 & 8 & 10 & 8 & 4 & 4 \\
Agland & 13 & 16 & 15 & 15 & 12 & 8 & 11 & 15 \\
Brush & 15 & 16 & 18 & 20 & 25 & 34 & 32 & 20 \\
Wood & 44 & 38 & 29 & 25 & 23 & 25 & 33 & 40 \\
\hline
\end{tabular}


Table 17. Distribution of vegetation with respect to slope aspect for slopes within the Arastradero lithofacies. Columns not totaling $100 \%$ result from numerical rounding.

\begin{tabular}{||l|c|c|c|c|c|c||}
\hline & $\begin{array}{c}\text { Bare } \\
(\%)\end{array}$ & $\begin{array}{c}\text { Grass } \\
(\%)\end{array}$ & $\begin{array}{c}\text { Scatter } \\
(\%)\end{array}$ & $\begin{array}{c}\text { Agland } \\
(\%)\end{array}$ & $\begin{array}{c}\text { Brush } \\
(\%)\end{array}$ & $\begin{array}{c}\text { Wood } \\
(\%)\end{array}$ \\
\hline $\mathrm{N}$ & 2 & 9 & 10 & 14 & 0 & 11 \\
$\mathrm{NE}$ & 8 & 12 & 19 & 15 & 0 & 15 \\
$\mathrm{E}$ & 21 & 18 & 25 & 12 & 0 & 29 \\
$\mathrm{SE}$ & 28 & 13 & 15 & 8 & 0 & 11 \\
$\mathrm{~S}$ & 27 & 14 & 10 & 10 & 0 & 9 \\
$\mathrm{SW}$ & 10 & 13 & 6 & 11 & 0 & 5 \\
$\mathrm{~W}$ & 3 & 10 & 8 & 12 & 0 & 8 \\
$\mathrm{NW}$ & 1 & 10 & 7 & 18 & 0 & 11 \\
\hline
\end{tabular}

Table 18. Distribution of vegetation with respect to slope aspect for slopes within the Stevens Creek lithofacies. Columns not totaling $100 \%$ result from numerical rounding.

\begin{tabular}{||l|c|c|c|c|c|c||}
\hline & $\begin{array}{c}\text { Bare } \\
(\%)\end{array}$ & $\begin{array}{c}\text { Grass } \\
(\%)\end{array}$ & $\begin{array}{c}\text { Scatter } \\
(\%)\end{array}$ & $\begin{array}{c}\text { Agland } \\
(\%)\end{array}$ & $\begin{array}{c}\text { Brush } \\
(\%)\end{array}$ & $\begin{array}{c}\text { Wood } \\
(\%)\end{array}$ \\
\hline $\mathrm{N}$ & 13 & 9 & 11 & 12 & 9 & 18 \\
$\mathrm{NE}$ & 21 & 11 & 11 & 18 & 11 & 17 \\
$\mathrm{E}$ & 26 & 26 & 17 & 22 & 18 & 19 \\
$\mathrm{SE}$ & 12 & 16 & 17 & 14 & 12 & 10 \\
$\mathrm{~S}$ & 8 & 13 & 18 & 9 & 12 & 7 \\
$\mathrm{SW}$ & 6 & 8 & 12 & 5 & 13 & 6 \\
$\mathrm{~W}$ & 5 & 8 & 7 & 8 & 14 & 9 \\
$\mathrm{NW}$ & 9 & 8 & 7 & 12 & 10 & 14 \\
\hline
\end{tabular}


facies. Within the Arastradero lithofacies, on slopes gentler than $80^{\circ}$, the failed percentages of slope angle intervals range from $15 \%\left(75-80^{\circ}\right.$ interval) to $28 \%\left(50-55^{\circ}\right.$ and $65-70^{\circ}$ intervals). In comparison, the minimum failure frequency within the stevens Creek lithofacies is $11 \%\left(0-5^{\circ}\right.$ and $5-10^{\circ}$ intervals), with a maximum failure frequency of $16 \%\left(45-50^{\circ}\right.$ interval). On slopes steeper than $80^{\circ}$, landslide occurrence becomes insignificant.

It appears that slope angle has little effect on the stability of slopes within the study area. Landslide frequency is proportional to the distribution of slope angle. Figure 3 shows that the distribution of the failed areas is proportional to the distribution of the total area of each interval, with the failed percentage of each interval remaining fairly constant within each lithofacies. The relatively higher failure frequencies within the Arastradero slope angle intervals reflects the higher degree of instability in this litrofacies. The nearly uniform distribution of landslides with respect to slope angle within both lithofacies suggests that some other factor is responsible for the increased instability of the Arastradero.

The occurrence of landslides on slopes steeper than $35^{\circ}$ may appear to be unexpected considering that a number of researchers have shown that landslides become uncommon on slopes steeper than $35^{\circ}$ (Radbruch and Crowther, 1973; Carrara and others, 1977b). However, this can be explained by the difference in methods used to evaluate the relation- 
ship between slope angle and landslide occurrence. In most landslide studies, the slope angle of a landslide is determined by measuring the angle of the slope adjacent to the landslide. This type of measurement produces an average value for slope angle, but the maximum and minimum slope angles are obscured in the average. In contrast, this study evaluated the slope angle of individual grid nodes falling within landslide boundaries. In general, the higher slope angle values represent the scarp areas and the lower values represent the toe areas of landslides. When the average slope angles are determined from the individual grid nodes, they can be expected to produce values comparable to the average values of slope attained using the other method. In general, shallow landslides are more abundant on gentle slopes and deep landslides are more common on moderate to steep slopes (Fig. 4). This relationship is more apparent in the Arastradero (Fig. 7) than in the Stevens Creek lithofacies (Fig. 8). It can be assumed that once the depths of the undifferentiated landslides are determined for each slope angle interval their values will form a shallowto-deep ratio similar to that established by the landslides of known depths. The most likely explanation for the correlation of landslide depth and slope angle is that surficial erosion processes on steep slopes differ from those on gentle slopes. On steep slopes, erosional debris is regularly transported down-slope by rain wash. In contrast, 
the gentler slopes tend to accumulate debris, resulting in the formation of colluvial deposits of varying thicknesses. These colluvial deposits are unstable relative to the underlying bedrock and are more susceptible to failure. Therefore, in the absence of these relatively thin mantles of colluvium, steep slopes will have fewer shallow failures of this nature. Another explanation to account for this trend has little to do with geologic processes; rather, it concerns the methods used in locating the depth of landslide failure planes. On gentle slopes, the angle at which exploratory borings are drilled into the subsurface is approximately perpendicular to the slope face, resulting in an observed depth to the failure plane and landslide thickness approximating their true values. On steeper slopes, the angles at which the borings are drilled can deviate significantly from perpendicular, resulting in an observed failure plane depth and landslide thickness somewhat greater than their actual values. However, this would only be significant for landslides whose thickness was close to the $3-\mathrm{m}$ division used in this study and therefore should not affect the observed trend between landslide depth and slope angle. The relationships between slope angle and slope aspect and slope angle and vegetation provide little insight into the proportional relationship between slope angle and landslides. Excluding the 75-90' slope angle interval, the distribution of slope aspect with respect to slope angle is fairly consistent throughout the study area (Table 1). The 
distribution of slope angle with respect to vegetation indicates that the distribution of vegetation is somewhat controlled by slope angle (Tables 7 and 8 ). This relationship may be used to explain the observed stability of the $75^{\circ}-90^{\circ}$ interval. Brushland and woodland cover $71 \%$ of the slopes within this interval, whereas grassland covers only 8\%. The root strength and erosional control provided by the brush and trees may reduce the possibility of slope failure. However, other factors such as the inherent strength of cliff-forming rocks or the relatively thin accumulation of colluvium on steep slopes may be equally important.

\section{Slope Aspect and Landslides}

The slope aspects within the study area exhibit a normal distribution (Fig. 9). East-facing slopes are the most common (25\%), whereas southwest-facing slopes are the least common ( $8 \%$ ). This trend is the same in both lithofacies, although the minimum occurrence of slope aspect is in southwest-facing slopes in the Stevens Creek (Fig. 12) and in west-facing slopes in the Arastradero (Fig. 11). North-, northeast-, and east-facing slopes are the most stable aspects within the study area, with failure frequencies between $10 \%$ and $11 \%$. It should be noted that the failure frequencies of these aspects are nearly identical for both the Arastradero and Stevens Creek lithofacies. This is somewhat unexpected considering that the overall distribution of failures on Arastradero slopes is almost 
twice that of Stevens Creek slopes. The remaining slope aspects show relatively less stability, with a substantial disparity existing between Arastradero and Stevens Creek slopes. Within the Stevens Creek Iithofacies, southeastand south-facing slopes are the most unstable, failing at a frequency of $17 \%$. Southwest- (15\%), northwest- (13\%), and west-facing slopes (12\%) fail less frequently. In contrast, within the Arastradero lithofacies, west-facing slopes fail at a maximum frequency of $43 \%$, with southwest- and northwest-facing slopes failing at frequencies of $36 \%$ and $35 \%$, respectively. South- (29\%) and southeast-facing slopes (22\%) also exhibit relatively high failure frequencies within the Arastradero. Based on these observations, it appears that slope aspect has a strong influence on slope stability, although other factors may contribute to the relationship. It appears from the available data that the distribution of slope aspects within each lithofacies does not account for the higher frequency of landslides within the Arastradero. Because the relative abundance of southerly and westerly slopes within each lithofacies is nearly the same, the almost doubled occurrence of slope failures in the Arastradero cannot simply be the result of this lithofacies containing more slopes of these aspects. Consequently, some parameter other than slope aspect appears to be responsible for the difference in stability between the lithofacies. The distribution of shallow and deep landslides appears to be partially controlled by slope aspect. Shallow land- 
slides are more abundant on east-, southeast-, south-, and southwest-facing slopes (Fig. 10), with the trend being more apparent within the Arastradero (Fig. 13) than within the Stevens Creek lithofacies. This trend can be correlated to the relationship between slope aspect and vegetation. The southerly slopes are covered primarily by grassland vegetation. Because of the shallow rooting characteristics of grasses, this type of vegetation has negligible ability to increase the stability of slopes. In contrast, on northerly slopes where trees are more abundant, shallow landslides are less common because the deep root systems increase the stability of shallow soils and strata. It can be assumed that once the depths of the undifferentiated landslides are determined, their values will form a shallow-to-deep ratio similar to that established by the landslides of known depth.

In fact, the relationship between slope aspect and vegetation can account for the greater abundance of all landslides on southerly and westerly slopes. These slopes are covered primarily by grassland vegetation, whereas northerly and easterly slopes are covered by relatively more woodland and brushland vegetation (Tables 13 and 14). It appears that the total number of landslides on aspects where these vegetal types are abundant is less than on aspects where they are more rare because the deep, wellspread root systems of woodland and brushland vegetation restrict the formation of shallow landslides. It follows 
that the relative stability of north-, northeast-, and eastfacing slopes in the Arastradero is attributable to the distribution of vegetation. These aspects are covered by the highest percentage of woodlands and the lowest percentage of grasslands within this lithofacies. Therefore, it appears that vegetation controls the distribution of landslides and slope aspect is correlated with the distribution of vegetation.

\section{Vegetation and Landslides}

Woodland is the most abundant vegetation within the study area, covering $31 \%$ of the slopes (Fig. 15). Grassland is also relatively abundant, comprising $20 \%$ of the vegetation. Brushland, agricultural land, and bare/residential land are all present in significant amounts. Scattered woodland/brushland covers less than $6 \%$ of the slopes within the study area. A large disparity exists in the distribution of vegetation within the Arastradero and Stevens Creek lithofacies (Figs. 17 and 18). Brushland vegetation, which comprises $21 \%$ of the Stevens Creek vegetation, is not present on Arastradero slopes. In addition, woodland vegetation, which covers $32 \%$ of the Stevens Creek slopes, occupies only $24 \%$ of the Arastradero slopes. In contrast, grasslands are present on $38 \%$ of the Arastradero slopes, covering only $17 \%$ of the Stevens Creek slopes. Agricultural land is also more abundant in the Arastradero, covering 23\% of the slopes, as opposed to $13 \%$ of the Stevens Creek slopes. Scattered 
woodland/brushland and bare/residential vegetation types are present in nearly equal proportions in both lithofacies. Grass-covered slopes within the study area are the most susceptible to slope instability. These slopes fail at a frequency of $25 \%$ within the study area, with failure frequencies of $31 \%$ in the Arastradero and $23 \%$ in the Stevens Creek lithofacies. The propensity of grass-covered slopes to fail has been well-documented by many researchers. One reason cited to explain the tendency of grass-covered slopes to fail is the greater infiltration capacity associated with this type of vegetation. In fact, infiltration capacities of grass-covered soils are two to four times the capacities of similar soils without vegetation (Cleveland, 1971). Only a small portion of the infiltrated water is subsequently used in plant transpiration. As a result, the increased moisture content in the soil and sub-strata can lead to increased pore-water pressure, hydration of clays, and lubrication of failure planes. Grassland vegetation also has weak and shallow rooting systems that provide little support to earth materials deeper than a few centimeters. It appears that the abundance of grassland vegetation within the Arastradero lithofacies is directly related to the greater occurrence of slope failures in this lithofacies. Agricultural land fails at the second highest rate, failing at a frequency of $24 \%$ in the Arastradero and $17 \%$ in the Stevens Creek lithofacies. The uses of the agricultural land are divided between orchards and grain hay 
fields; therefore, it is not surprising to see its failure frequency ( $19 \%$ ) lie between the failure frequencies of scattered woodland/brushland (17\%) and grassland (25\%). Orchards behave as scattered woodland/brushland in that, although their root systems are generally well developed and extend to considerable depths, their sparse distribution does not allow an inter-locking root system to develop (Cleveland, 1971). Similarly, grain hay fields resemble grassland in that both increase the infiltration capacity of the soil and have weak, shallow rooting systems. The amount of water added to the slopes through irrigation can be considered negligible because the large majority of the agriculture is based on dryland crops, although locally irrigation may be more intense. The greater instability of the Arastradero lithofacies may be related to the greater abundance of this relatively unstable type of vegetation. Woodland and brushland represent the native vegetation with the highest degree of stability within the study area, with failure frequencies of $15 \%$ and $11 \%$, respectively. However, it should be noted that it is more difficult to identify landslides that are covered by dense forest or brush, especially when using air photos. In addition, areas that are covered by woodland and brushland are less likely to have been investigated for the presence of landslides. These types of vegetation are believed to increase the stability of a slope for a number of reasons: 1) the dense vegetation intercepts rainfall, causing absorptive and 
evaporative losses that reduce the amount left for infiltration; 2) the roots extract moisture from the soil, reducing pore-water pressures; 3) the root networks increase the shear resistance of the soil and may anchor the soil into the underlying strata; and 4) the roots bind particles to the surface, reducing surficial erosion (Greenway, 1987). Furthermore, the varieties of trees and brush present in the study area exhibit relatively deep (up to $18 \mathrm{~m}$ ) and well-spread root systems, high water use, and high tensile strength (Greenway, 1987). The relatively high infiltration capacity associated with woodland vegetation would normally lead to a decrease in slope stability; however, this is offset by the high water use and root strength provided by the trees. The greater abundance of woodland vegetation in the Stevens Creek lithofacies may be responsible for the greater stability of this lithofacies.

Bare/residential land exhibits the lowest failure frequency $(9 \%)$ of the six classes of vegetation. As previously mentioned, bare slopes can often be expected to be less susceptible to failure than grass-covered slopes because of their lower infiltration capacity; although they would be more vulnerable to surficial erosion. It should be taken into account that the majority of bare/residential land is associated with human activities or residential developments. Therefore, it can be assumed that detailed geotechnical investigations had been conducted on the stability of these areas prior to their development. Conse- 
quently, the percentage of these areas that have failed should be relatively low.

The distribution of shallow and deep landslides is partially controlled by vegetation (Fig. 16). The majority of landslides occurring on grass-covered slopes are shallow. This suggests that even at shallow depths the weak, shallow root systems provide little stability. In contrast, shallow landslides are less frequent in woodland terrains, where the deep, well-spread root systems increase the shearing resistance of shallow soils and strata. In general, shallow landslides are more common in agricultural land and scattered woodland/brushland terrains; although landslides in the agricultural land of the Arastradero lithofacies deviates from this generalization. This suggests that sparsely distributed trees and brush do not provide sufficient root strength to control shallow failures. Failures within brushland terrains are evenly distributed between shallow and deep, indicating that the root depths and strengths are not as restrictive as those of woodland vegetation. Deep landslides are by far more abundant than shallow landslides on bare/residential slopes: the reason for this is unclear. It can be assumed that once the depths of the undifferentiated landslides are determined for each type of vegetation, their values will form a shallow-to-deep ratio similar to that established by the landslides of known depths. Although slope angle does not appear to be a critical stability factor, a number of interrelationships between 
vegetation and slope angle are present (Tables 7 and 8 ). Brushland is more abundant on steeper slopes. In contrast, bare/residential land, grassland, and agricultural land are more abundant on shallow slopes. Woodland and scattered woodland/brushland are distributed fairly uniformly with respect to slope angle, peaking on slopes exceeding $60^{\circ}$.

The interrelationships between vegetation and slope aspect within the study area (Tables 13 and 14) are similar to that reported by many researchers. Grassland vegetation is most abundant on southerly slopes (39\%), which tend to be drier than northerly slopes. Woodland vegetation is most abundant on northerly slopes $(47 \%)$, which tend to contain more moisture. Agricultural land, which is relatively unstable, also tends to be concentrated on northerly slopes (43\%). The difference in stability between agricultural land and the relatively stable woodland can be attributed to the greater rooting strength and water use characteristics of the woodland vegetation. Brushland, which represents the most stable native vegetation type, is fairly evenly distributed on each slope aspect. Bare/residential land, which occupies the most stable slopes, is most abundant on the wetter northerly and easterly slopes.

\section{Geology and Landslides}

Landslides occupy $13 \%$ of the Stevens Creek slopes and $24 \%$ of the Arastradero slopes. If all other factors were equal, these values would indicate that the Stevens Creek 
strata are more stable than the Arastradero. However, because the slope angle, slope aspect, and vegetation are unevenly distributed between the two lithofacies, their influence must be accounted for before the relative geologic stability of each lithofacies can be determined.

In order to minimize the variability between the two lithofacies, the slopes that share the most common distributions of slope angle, slope aspect, and vegetation were determined. Tables 1 through 18 indicate that grasslands and woodlands share the most common distributions of slope angle and slope aspect within the two lithofacies. These tables also indicate that east- and southeast-facing slopes share the most common distributions of slope angle and vegetation within the two lithofacies and that the 15-30。 and $0-15^{\circ}$ intervals share the most common distributions of slope aspect and vegetation between the two lithofacies. The differences in the failure frequencies of these six subclasses were determined to evaluate the relative geologic stability of the two lithofacies. The largest difference in relative stability exists between the woodland vegetation failure frequencies, with woodlands failing at a frequency of $27 \%$ in the Arastradero (Fig. 17) and $13 \%$ in the Stevens Creek (Fig. 18). The smallest difference exists between the east-facing failure frequencies, with failure frequencies of $11 \%$ in both lithofacies (Figs. 11 and 12). The average difference in failure frequencies of the six subclasses is 7\%. This value approximately represents the difference in 
the observed geologic stability between the two lithofacies, with the Arastradero (24\% failed) being relatively less stable than the Stevens Creek (13\% failed). The discrepancy between the expected difference in relative stability (7\%) and the observed difference $(11 \%)$ can be attributed to the influence of other factors that are unevenly distributed between the two lithofacies.

The 7\% difference in relative geologic stability determined above is based on a number of assumptions. Geology is the most basic parameter of slope stability. It controls, among other factors, the distribution of slope angles, vegetation, geotechnical properties, and hydrogeology. The Arastradero and Stevens Creek lithofacies contain similar rock types and have experienced similar depositional and post-depositional histories. Therefore, it is not surprising that the stabilities of the two lithofacies are relatively similar. However, a number of geologic dissimilarities exist that can explain the relative instability of the Arastradero Iithofacies. The Arastradero lithofacies represents the deposition of weathered older Tertiary and Mesozoic rocks in coarse-grained braided stream, floodplain, and lacustrine environments, whereas the Stevens Creek lithofacies was formed by the deposition of weathered older Tertiary and Franciscan rocks in fluvial and debris flow environments (Vanderhurst, 1981). The different source terrains and depositional environments have resulted in rocks of different composition and texture that may affect 
their geotechnical properties. For example, the Arastradero lithofacies is believed to have been deposited farther from its source terrain than the Stevens Creek lithofacies; therefore, its rocks are typically composed of finer sediments. In addition, the stevens Creek is generally considered to be moderately indurated, whereas the Arastradero is poorly indurated. This may explain the frequency of landslides occurring along the contact between the Arastradero and Stevens Creek lithofacies (Plate 1), where a competency contrast exists between the rocks. Furthermore, faults within the Arastradero appear to be more abundant and pervasive than in the Stevens Creek, where they are less abundant and generally discontinuous. A number of landslides within the Arastradero lithofacies appear to be controlled by faults (Plate 1). Faults have been shown to foster instability because they commonly juxtapose rocks of differing strengths against one another, act as primary failure planes, provide conduits for the infiltration of water, and create groundwater barriers.

The distribution of shallow and deep landslides is approximately the same within the two lithofacies, occurring at a ratio of nearly 1:1. It can be assumed that once the depths of the undifferentiated landslides are determined for the Stevens Creek lithofacies, their values will form a shallow-to-deep ratio similar to that established by the landslides of known depths. 


\section{Landslide Potential Map}

A Landslide Potential Map (Plate 3) was created by combining the hazards associated with geology, slope angle, slope aspect, and vegetation. Hazard ratings were generated for each grid node by summing the failure frequencies of each factor for each grid node position. Hazard ratings for each lithofacies were evaluated separately in order to account for lithologic variations. The failure frequencies used in the calculations were taken from the numbers in parenthesis in Figures $5,6,11,12,17$, and 18 .

Hazard grids were created from the slope angle, slope aspect, and vegetation data grids in the following manner:

1) Boolean grids of each slope angle interval were multiplied by their respective failure frequency using the "gridMath" function of Gridzo 6.0 slope angle grid nodes in the stevens Creek lithofacies between $10-15^{\circ}$ were assigned a value of 14 . After a failure frequency value had been assigned to every grid node in each slope angle interval, the modified Boolean slope angle grids were combined to create the "slope angle hazard grid."

2) Boolean grids for each slope aspect octant were multiplied by their respective failure frequency. For example, all slope aspect grid nodes in the stevens Creek lithofacies representing north-facing slopes were assigned a value of 10 . After a failure frequency value had been assigned to each slope aspect octant, 
the modified Boolean slope aspect grids were combined to create the "slope aspect hazard grid."

3) Boolean grids for each category of vegetation were multiplied by their respective failure frequency. For example, all vegetation grid nodes in the stevens Creek lithofacies representing grassland were assigned a value of 23 . After a failure frequency value had been assigned to each category of vegetation, the modified Boolean vegetation grids of each vegetation category were combined to create the "vegetation hazard grid."

The slope angle, slope aspect, and vegetation hazard grids of each lithofacies were combined and added to form the "combined hazard grid." For example, using the above information, a grid node representing a north-facing slope (hazard value of 10 ) with a gradient between 10-15 (hazard value of 14) that is grass-covered (hazard value of 23) would have a combined hazard value of 47 . The combined hazard grids were compared to the landslide grid to determine the percentage of each combined hazard value that represents failed slopes. This was accomplished by comparing the Boolean grid of each combined hazard value with the Boolean landslide grid using the "Blogic" function of Gridzo 6. $0^{\text {Tu}}$. For example, a Boolean grid for the combined hazard value of 47 was created and compared to the Boolean grid of all landslides. The number of grid nodes representing the 
combined hazard value of 47 that fell within the boundaries of the landslides was divided by the total number of grid nodes of that hazard value. The quotient represents the failure frequency of that combined hazard value. For example, if there were a total of 3000 grid nodes representing the combined hazard value of 47 , and 1000 of those grid nodes corresponded to landslide grid nodes, the result would be a failure frequency of $33 \%$. The combined hazards were then divided into five arbitrary categories based on their failure frequency: $>50 \%, 30-50 \%, 15-30 \%, 1-15 \%$, and $<1 \%$. The ranges of combined hazard values comprising each category are shown in Table 19.

Table 19. Combined hazard values comprising the five failure frequency categories of the Arastradero and Stevens Creek Lithofacies.

\begin{tabular}{||c|c|c||}
\hline $\begin{array}{l}\text { Failure } \\
\text { Frequency }\end{array}$ & $\begin{array}{c}\text { Arastradero } \\
\text { Combined Hazard }\end{array}$ & $\begin{array}{c}\text { Stevens Creek } \\
\text { Combined Hazard }\end{array}$ \\
\hline$>50 \%$ & $70-96$ & $48-56$ \\
$30-50 \%$ & $59-70$ & $43-48$ \\
$15-30 \%$ & $53-59$ & $39-43$ \\
$1-15 \%$ & $31-53$ & $24-39$ \\
$<1 \%$ & $24-31$ & $18-24$ \\
\hline
\end{tabular}

The combined hazard grid nodes representing each of the five failure frequency categories were individually plotted onto a topographic base map using the "Zapatone" function of 
Gridzo 6.0 $0^{\mathrm{m}}$. Each category was plotted on a separate base map to allow for editing. Individual grid nodes or groups of nodes too small to be represented on the final map scale were reassigned to the next lower failure frequency category. An illustration of the data before the reassignment of grid nodes for a single failure category of a portion of the study area is shown in Figure 21. The five edited plots were transposed onto a single topographic map to create the Landslide Potential Map (Plate 3).

The Landslide Potential Map graphically depicts areas of relative stability and instability based on the combined influence of the factors of geology, slope angle, slope aspect, and vegetation. When the Landslide Potential Map is compared to the actual distribution of landslides (Plate 1), a high correlation is seen between the higher combined hazard categories and actual landslide occurrence. Based on this high correlation, it is likely that slopes representing the higher combined hazard categories that are currently stable will experience slope failure in the future. In contrast, stable slopes that lie within the lower combined hazard categories are likely to remain stable under current environmental conditions. 


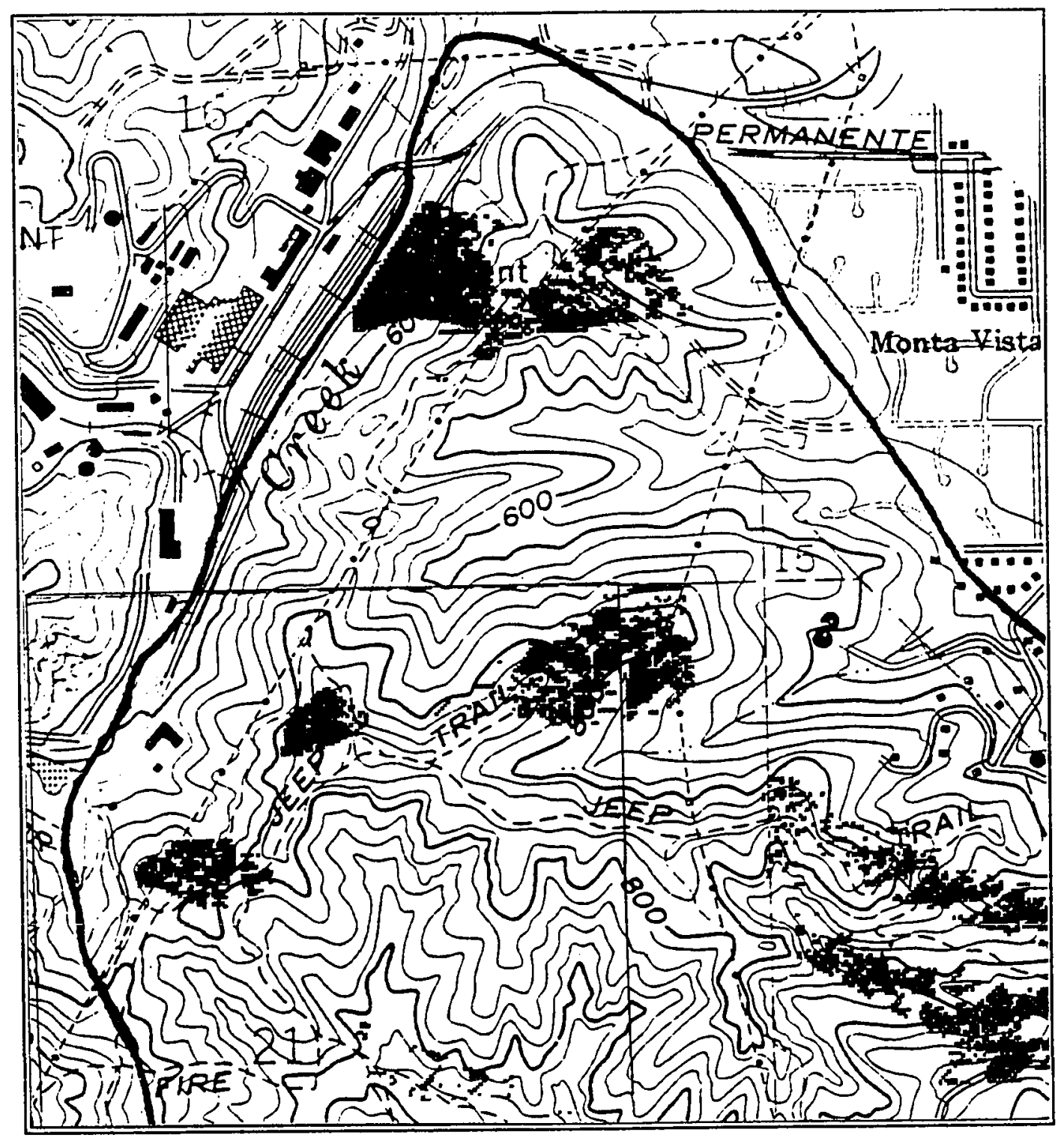

Figure 21. An example of a pre-edited plot of a failure frequency category of a portion of the Landsidide Potential Map. 


\section{SITE-SPECIFIC INVESTIGATION}

A "site-specific investigation" was conducted for the factors of geotechnical properties, structural relationships, and slope form. Because of heterogeneities in soil properties and slope form, it would be difficult to project the hazards associated with these factors on a regional scale. However, the results of this portion of the study can be extrapolated to other localities on a site-by-site basis.

\section{Geotechnical Properties}

\section{Data Compilation and Manipulation}

The engineering, physical, and mineralogical properties used for this study were compiled from numerous unpublished reports. Data were gathered for the properties of Atterberg Limits, residual shear strength, inplace dry density, natural moisture content, median grain size, percent clay content, and clay mineralogy. The majority of the data were taken from Nelson's (1985) investigation of the geotechnical and geologic properties of the Santa Clara Formation claystone. Additional data were collected from unpublished geotechnical reports from the files of William cotton and Associates. This part of the investigation focuses on the geotechnical properties of claystones, mudstones, and siltstones, which Nelson (1985) found to be present in $90 \%$ of the borings and trenches located within landslide masses during his investigation of the study area. 
For the basis of comparison, the data were divided into four categories reflecting the site of sample collection: (1) stable, (2) Iandslide plane, (3) landslide mass, and (4) erosional. Samples from stable areas were collected as bulk samples from road-cuts and stream beds in areas unaffected by slope instability. Landslide plane samples were collected as bulk samples from exposed landslide scarps or as exploratory boring core samples from failure planes. Landslide mass samples were collected as bulk samples from exploratory trenches or as core samples from exploratory borings located within the boundaries of landslides. Erosional samples were collected as bulk samples from erosional scarps.

Because of insufficient data from each of the lithofacies, a direct comparison of properties between the Arastradero and Stevens Creek was not possible, with the exception of inplace dry density and natural moisture content values. However, the lithology of each sample is indicated in the various appendices in this section to allow preliminary comparisons to be made.

\section{Results}

Atterberg Limits. Atterberg Limit values for 64 samples are shown in Appendix A. The 64 samples represent 14 samples collected from stable areas, 9 from landslide planes, 33 from landslide masses, and 8 from erosional scarps. Each data source reported that the Atterberg Limits were measured in accordance with American Society of Testing 
and Materials Test Method D4318-83 (American Society of Testing and Materials, 1984).

The statistics of Liquid Limit and Plastic Limit values for each of the four categories are shown in Table 20.

Table 20. Statistics of Liquid Limit and Plastic Limit values (modified from Nelson, 1985). Symbols used: $\mathrm{n}=$ number of samples, $\mu=$ mean, $\sigma=$ one standard deviation.

\begin{tabular}{|c|c|c|c|c|c|c|c|c|}
\hline \multirow[b]{2}{*}{ type } & \multicolumn{4}{|c|}{$\begin{array}{l}\text { LIQUID LIMIT } \\
(\% \text { dry weight) }\end{array}$} & \multicolumn{4}{|c|}{$\begin{array}{l}\text { PLASTIC LIMIT } \\
\text { (\% dry weight) }\end{array}$} \\
\hline & $\mu$ & $\sigma$ & hi & 10 & $\mu$ & $\sigma$ & hi & 10 \\
\hline $\begin{array}{c}\text { Stable } \\
(\mathrm{n}=14)\end{array}$ & 54 & 8.2 & 67 & 41 & 21 & 5.0 & 36 & 17 \\
\hline $\begin{array}{c}\text { Slide } \\
\text { Plane } \\
(n=9)\end{array}$ & 68 & 7.7 & 82 & 56 & 22 & 3.0 & 25 & 17 \\
\hline $\begin{array}{l}\text { Slide } \\
\text { Mass } \\
(n=33)\end{array}$ & 65 & 15.1 & 107 & 41 & 24 & 4.7 & 40 & 17 \\
\hline $\begin{array}{l}\text { Erosion } \\
(n=8)\end{array}$ & 65 & 18.5 & 88 & 45 & 22 & 3.4 & 29 & 17 \\
\hline
\end{tabular}

Residual shear strength. Values of residual friction angle for 19 samples are presented in Appendix B. The 19 samples represent 5 samples collected from stable areas, 10 from landslide planes, and 4 from erosional scarps. 
The statistics of residual friction angle values for each of the three categories are shown in Table 21 .

Table 21. Statistics of residual friction values (modified from Nelson, 1985). Symbols used: $\mathrm{n}=$ number of samples, $\mu=$ mean, $\sigma=$ one standard deviation.

\begin{tabular}{|c|c|c|c|c|}
\hline \multirow[b]{2}{*}{ type } & \multicolumn{4}{|c|}{$\begin{array}{l}\text { RESIDUAL FRICTION ANGLE } \\
\text { (degrees) }\end{array}$} \\
\hline & $\mu$ & $\sigma$ & high & low \\
\hline $\begin{array}{l}\text { Stable } \\
(n=5)\end{array}$ & 16.1 & 6.8 & 24.5 & 7.0 \\
\hline $\begin{array}{l}\text { Slide } \\
\text { Plane } \\
(n=10)\end{array}$ & 7.5 & 1.3 & 9.5 & 5.0 \\
\hline $\begin{array}{l}\text { Erosional } \\
(n=4)\end{array}$ & 11.2 & 6.8 & 20.4 & 6.0 \\
\hline
\end{tabular}

\section{Inplace Dry Density and Natural Moisture Content.}

Values of inplace dry density and natural moisture content for 107 samples are shown in Appendix C. The 107 samples represent 11 samples collected from landslide planes and 96 samples collected from landslide masses. Because there was a large amount of data available, it was possible to compare the values of samples collected from the Arastradero and Stevens Creek Iithofacies. 
The statistics of inplace dry density for both categories of samples from each lithofacies are shown in Table 22. Natural moisture content statistics for the same samples are shown in Table 23 .

Table 22. Statistics of inplace dry density values. Symbols used: $\mathrm{n}=$ number of samples, $\mu=$ mean, $\sigma=$ one standard deviation.

\begin{tabular}{|c|c|c|c|c|c|}
\hline \multirow[b]{2}{*}{$\underline{\mathrm{n}}$} & \multirow{3}{*}{$\begin{array}{l}\text { type } \\
\text { Arastradero } \\
\text { slide Plane }\end{array}$} & \multicolumn{4}{|c|}{$\begin{array}{c}\text { INPLACE DRY DENSITY } \\
(\mathrm{pCf})\end{array}$} \\
\hline & & $\mu$ & $\sigma$ & high & low \\
\hline 4 & & 87 & 3.7 & 91 & 82 \\
\hline 7 & $\begin{array}{l}\text { Stevens Creek } \\
\text { Slide Plane }\end{array}$ & 90 & 3.1 & 96 & 86 \\
\hline 52 & $\begin{array}{l}\text { Arastradero } \\
\text { Slide Mass }\end{array}$ & 105 & 7.2 & 122 & 92 \\
\hline 44 & $\begin{array}{l}\text { Stevens Creek } \\
\text { Slide Mass }\end{array}$ & 106 & 5.2 & 115 & 90 \\
\hline
\end{tabular}


Table 23. Statistics of natural moisture content values (modified from Nelson, 1985). Symbols used: $\mathrm{n}=$ number of samples, $\mu=$ mean, $\sigma=$ one standard deviation.

\begin{tabular}{||c|l|c|c|c|c||}
\hline \multicolumn{2}{|c|}{} & \multicolumn{4}{|c|}{ MOISTURE CONTENT } \\
(\%) \\
\hline n & $\begin{array}{l}\text { type } \\
\text { Arastradero } \\
\text { Slide Plane }\end{array}$ & 35 & 1.7 & 37 & 33 \\
\cline { 2 - 6 } 7 & $\begin{array}{l}\text { Stevens Creek } \\
\text { Slide Plane }\end{array}$ & 30 & 3.2 & 33 & 24 \\
\hline 52 & $\begin{array}{l}\text { Arastradero } \\
\text { Slide Mass }\end{array}$ & 20 & 4.8 & 31 & 11 \\
\hline 44 & $\begin{array}{l}\text { Stevens Creek } \\
\text { Slide Mass }\end{array}$ & 20 & 3.5 & 27 & 12 \\
\hline
\end{tabular}

Percent Clay Content and Median Grain Size. Values of percent clay content and median grain size for 30 samples are presented in Appendix D. Clay is defined as particles finer than 2 microns $(.002 \mathrm{~mm})$. The 30 samples represent 13 samples collected from stable areas, 9 from landslide planes, and 8 from erosional scarps.

The statistics of percent clay content for each of the three categories are shown in Table 24 . The statistics of median grain size for the same samples are presented in Table 25 . 
Table 24. Statistics of percent clay content values (modified from Nelson, 1985). Clay is defined as particles finer than 2 microns $(.002 \mathrm{~mm})$. Symbols used: $\mathrm{n}=$ number of samples, $\mu=$ mean, $\sigma=$ one standard deviation.

\begin{tabular}{||l|c|c|c|c||}
\hline & \multicolumn{4}{|c|}{ PERCENT CLAY CONTENT } \\
& \multicolumn{4}{|c|}{$(\%)$} \\
\hline type & $\mu$ & $\sigma$ & high & low \\
\cline { 2 - 5 } $\begin{array}{c}\text { Stable } \\
(\mathrm{n}=13)\end{array}$ & 32 & 8.2 & 49 & 18 \\
\hline $\begin{array}{l}\text { Slide } \\
\text { Plane } \\
(\text { n=9) }\end{array}$ & 45 & 9.0 & 56 & 32 \\
\hline $\begin{array}{c}\text { Erosional } \\
(\text { n=8) }\end{array}$ & 45 & 19.0 & 70 & 25 \\
\hline
\end{tabular}

Table 25. Statistics of median grain size values (modified from Nelson, 1985). Symbols used: $\mathrm{n}=$ number of samples, $\mu=$ mean, $\sigma=$ one standard deviation.

\begin{tabular}{||c|c|c|c|c||}
\hline & \multicolumn{4}{|c|}{ MEDIAN GRAIN SIZE } \\
\hline \multirow{2}{*}{ type } \\
$\begin{array}{c}\text { Stable } \\
(\mathrm{n}=13)\end{array}$ & .0059 & .0033 & .0160 & .0021 \\
\cline { 2 - 5 } & & $\sigma$ & high & low \\
\hline $\begin{array}{c}\text { Slide } \\
\text { Plane } \\
(\mathrm{n}=9)\end{array}$ & .0028 & .0012 & .0048 & .0012 \\
\hline $\begin{array}{c}\text { Erosional } \\
\text { (n=8) }\end{array}$ & .0038 & .0027 & .0078 & .0005 \\
\hline
\end{tabular}


Clay Mineralogy. The relative amounts of kaolinite, illite, and smectite in 30 samples are shown in Appendix E. The 30 samples represent 13 samples collected from stable areas, 9 from landslide planes, and 8 from erosional scarps. The statistics of the abundances of the three clay minerals in samples from each category are presented in Table 26. Quantities represent percentage of total sample. The relative abundances of each of the three clay minerals was also determined (Table 27). These values represent the percentages of each mineral type within the clay-mineral fractions of the samples. 
Table 26. Abundance of kaolinite, illite, and smectite (modified from Nelson, 1985). Quantities represent percentage of total sample. Symbols used: $\mathrm{n}=$ number of samples, $\mu=$ mean, $\sigma=$ one standard deviation.

\begin{tabular}{|c|c|c|c|c|}
\hline & & $\begin{array}{l}\text { Stable } \\
(n=13)\end{array}$ & $\begin{array}{c}\text { Slide Plane } \\
(n=9)\end{array}$ & $\begin{array}{c}\text { Erosional } \\
\quad(n=8)\end{array}$ \\
\hline \multirow[t]{4}{*}{$\begin{array}{c}\text { Kaolinite } \\
(\%)\end{array}$} & $\mu$ & 10.3 & 16.2 & 13.3 \\
\hline & $\sigma$ & 7.7 & 7.8 & 11.7 \\
\hline & high & 30.4 & 26.3 & 30.8 \\
\hline & low & 0 & 2.4 & 0.9 \\
\hline \multirow[t]{4}{*}{$\begin{array}{l}\text { Illite } \\
(\%)\end{array}$} & $\mu$ & 5.7 & 4.5 & 3.9 \\
\hline & $\sigma$ & 4.9 & 2.7 & 3.5 \\
\hline & high & 17.0 & 10.1 & 10.5 \\
\hline & low & 0 & 1.5 & 0 \\
\hline \multirow[t]{4}{*}{$\begin{array}{l}\text { Smectite } \\
\left(\frac{o}{6}\right)\end{array}$} & $\mu$ & 16.3 & 23.8 & 27.5 \\
\hline & $\sigma$ & 6.6 & 6.6 & 9.0 \\
\hline & high & 30.9 & 37.0 & 40.0 \\
\hline & low & 2.9 & 16.0 & 13.7 \\
\hline
\end{tabular}


Table 27. Relative abundance of kaolinite, illite, and smectite (modified from Nelson, 1985). Quantities represent percentages of each mineral type within the clay-mineral

fractions of samples. Symbols used: $n$ = number of samples, $\mu=$ mean, $\sigma=$ one standard deviation.

\begin{tabular}{|c|c|c|c|c|}
\hline & & $\begin{array}{c}\text { Stable } \\
(n=13)\end{array}$ & $\begin{array}{c}\text { Slide Plane } \\
(n=9)\end{array}$ & $\begin{array}{c}\text { Erosional } \\
(\mathrm{n}=8)\end{array}$ \\
\hline \multirow[t]{4}{*}{$\begin{array}{c}\text { Kaolinite } \\
(\%)\end{array}$} & $\mu$ & 30.1 & 35.5 & 26.5 \\
\hline & $\sigma$ & 16.7 & 13.4 & 17.3 \\
\hline & high & 66.1 & 55.4 & 44.4 \\
\hline & low & 0 & 5.9 & 3.0 \\
\hline \multirow[t]{4}{*}{$\begin{array}{l}\text { IIIite } \\
(\%)\end{array}$} & $\mu$ & 16.4 & 10.0 & 8.0 \\
\hline & $\sigma$ & 12.3 & 4.9 & 5.3 \\
\hline & high & 43.6 & 17.8 & 15.2 \\
\hline & low & 0 & 3.7 & 0 \\
\hline \multirow[t]{4}{*}{$\begin{array}{c}\text { Smectite } \\
\left(\frac{\circ}{\sigma}\right)\end{array}$} & $\mu$ & 53.5 & 54.5 & 65.5 \\
\hline & $\sigma$ & 21.4 & 15.8 & 20.6 \\
\hline & high & 100 & 90.5 & 97.0 \\
\hline & Iow & 6.3 & 33.7 & 40.4 \\
\hline
\end{tabular}




\section{Structural Relationships}

\section{Data Compilation and Manipulation}

Data for bedrock orientation, direction of landslide movement, and slope angle were collected for 57 landslides (Appendix F). Forty-three data sets were compiled from Orris's (1979) quantitative investigation of landslides in a portion of the Santa Clara Formation. An additional 14 data sets were measured and recorded for landslides included in this study that were not included on Orris's map.

The data were gathered to determine if the disposition of bedding attitudes in relation to slope inclination has an influence on slope stability. In order to explore this possible relationship, three values were calculated from the collected data:

1) the degree of parallelism between the slope face and the bedding plane discontinuity ("angle from parallelism") was determined by calculating the angle between the direction of landslide movement and the dip direction of the bedding plane discontinuity.

2) the "dip difference" was calculated by subtracting the slope angle from the dip of the bedding plane discontinuity. This value takes into consideration the orientation of the slope face relative to the bedding plane, but it is approximate because the true dip angle perpendicular to bedding was used, not the apparent dip in the direction of the slope. 
3) the orientation of the slope face relative to the bedding plane ("slope type") was determined. Dip slopes are slopes that have bedding dips in the same direction as the slope face, whereas anti-dip slopes are ones that have bedding dips in the opposite direction as the slope face.

\section{Results}

Values of the angle from parallelism and dip difference, and a designation of slope type for each landslide, are included in Appendix F. Included in the appendix is an estimation of whether or not a "day-lighting" intersecting plane was present. This estimation was based on the three criteria established by Hoek and Bray (1974), discussed on Page 24 , required to create a potentially unstable environment for bedding plane failures.

The frequency of landslides with respect to the angle from parallelism is illustrated in Figure 22. Included in this figure is a comparison between dip and anti-dip slopes.

\section{Slope Form}

\section{Data Compilation and Manipulation}

Vertical and horizontal (plan) slope profiles were determined for 54 event sites. The profiles were estimated from Plate 1 and were separated into three categories: uniform, concave, and convex. Profiles were estimated from the slopes adjacent to the landslides in order to evaluate 


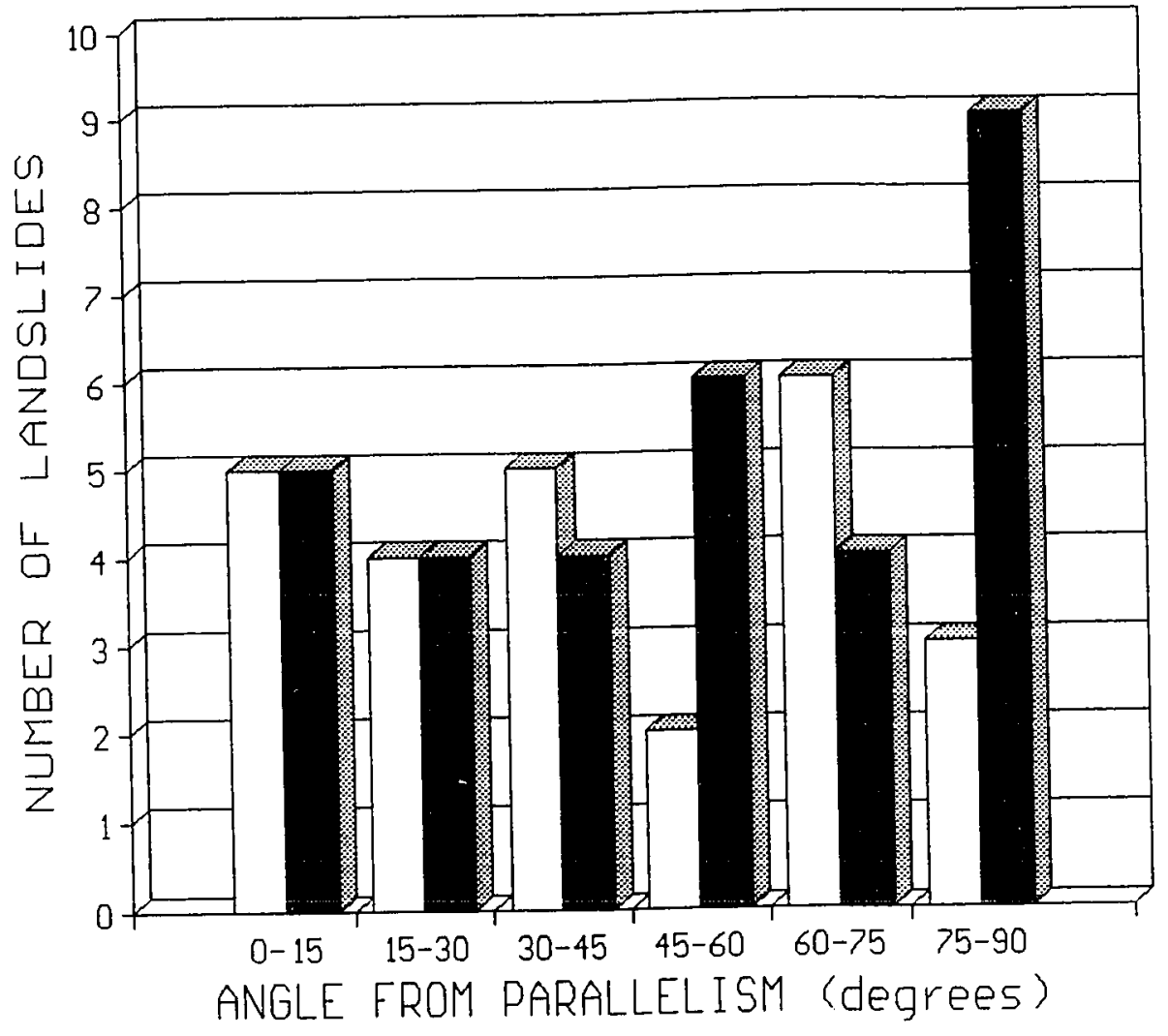

$\square$ Dip Slopes $\square$ Ant 1 -dip Slopes

Figure 22. Distribution of landslides with respect to the angle from parallelism between the bedding plane discontinuity and the direction of landslide movement. Landslides representing both dip and anti-dip slopes are included. 
their pre-failure slope forms. When the slope form was questionable, the profiles were further studied on 1:12000 scale air photos. Data were not collected from locations where erosional processes have produced large modifications to slope form since the time of landslide inception.

\section{Results}

The distribution of horizontal and vertical profiles for 54 landslide sites within the study area is shown in Table 28. For the basis of comparison, the distribution of slopes profiles was determined for landslide sites within the Arastradero lithofacies (Table 29) and the Stevens Creek lithofacies (Table 30 ). Table 31 and Table 32 contain the distributions of slope profiles for shallow and deep landslide sites, respectively.

Table 28. Distribution of vertical and horizontal (plan) profiles of 54 landslide sites within the study area. values represent percent occurrence. Totals not equaliing $100 \%$ result from numerical rounding.

\begin{tabular}{|c|c|c|c|c|}
\hline Profile & $\begin{array}{l}\text { Plan } \\
\text { Uniform }\end{array}$ & Concave & Convex & Total \\
\hline Uniform & 35 & 15 & 7 & 57 \\
\hline Concave & 7 & 17 & 11 & 35 \\
\hline Convex & 7 & 0 & 0 & 7 \\
\hline Total & 49 & 32 & 18 & 99 \\
\hline
\end{tabular}


Table 29. Distribution of vertical and horizontal (plan) profiles of 14 landslide sites within the Arastradero lithofacies. Values represent percent occurrence.

\begin{tabular}{|c|c|c|c|c|}
\hline Profile & $\begin{array}{l}\text { Plan } \\
\text { Uniform }\end{array}$ & Concave & Convex & Total \\
\hline Uniform & 46 & 15 & 0 & 61 \\
\hline Concave & 8 & 8 & 15 & 31 \\
\hline Convex & 8 & 0 & 0 & 8 \\
\hline Total & 62 & 23 & 15 & 100 \\
\hline
\end{tabular}

Table 30. Distribution of vertical and horizontal (plan) profiles of 40 landslide sites within the Stevens Creek lithofacies. Values represent percent occurrence. Totals not equalling $100 \%$ result from numerical rounding.

\begin{tabular}{||c|c|c|c|c||}
\hline \multirow{2}{*}{$\begin{array}{l}\text { Profile } \\
\text { Uniform }\end{array}$} & \multicolumn{4}{|l}{$\begin{array}{l}\text { Plan } \\
\text { Uniform }\end{array}$} \\
\cline { 2 - 5 } $\begin{array}{l}\text { Concave } \\
\text { Convex } \\
\text { Total }\end{array}$ & 33 & 15 & 8 & 56 \\
\cline { 2 - 5 } & 8 & 20 & 10 & 38 \\
\cline { 2 - 6 } & 89 & 0 & 0 & 8 \\
\hline
\end{tabular}


Table 31. Distribution of vertical and horizontal (plan) profiles of 16 shallow landslides. Values represent percent occurrence. Totals not equalling $100 \%$ result from numerical rounding.

\begin{tabular}{|c|c|c|c|c|}
\hline Profile & $\begin{array}{l}\text { Plan } \\
\text { Uniform }\end{array}$ & Concave & Convex & Total \\
\hline Uniform & 31 & 6 & 19 & 56 \\
\hline Concave & 0 & 13 & 13 & 26 \\
\hline Convex & 19 & 0 & 0 & 19 \\
\hline Total & 50 & 19 & 32 & 101 \\
\hline
\end{tabular}

Table 32. Distribution of vertical and horizontal (plan) profiles of 19 deep landslides. Values represent percent occurrence. Totals not equalling $100 \%$ result from numerical rounding.

\begin{tabular}{|c|c|c|c|c|}
\hline Profile & $\begin{array}{l}\text { Plan } \\
\text { Uniform }\end{array}$ & Concave & Convex & Total \\
\hline Uniform & 26 & 21 & 5 & 52 \\
\hline Concave & 16 & 26 & 5 & 47 \\
\hline Convex & 0 & 0 & 0 & 0 \\
\hline Total & 42 & 47 & 10 & 99 \\
\hline
\end{tabular}




\section{Discussion}

Geotechnical Properties

Atterberg Limits. The statistics in Table 20 indicate that the mean Liquid Limit (LL) value of slide plane samples is $14 \%$ higher than the mean value of samples from stable areas, representing a $26 \%$ relative difference. In contrast, the mean Plastic Limit (PL) value of slide plane samples is only $1 \%$ higher than the mean value of samples from stable areas. The $14 \%$ relative difference between the mean $\mathrm{PI}$ values of slide plane and stable samples suggests that the $\mathrm{PL}$ is not as critical a stability factor as the LL is for soils and rocks within the study area. Furthermore, because the mean PL values of the four sample categories are comparable, the differences in Plasticity Index (PI; PI=LL-PL) between the four categories reflect the variation of their LI values.

The evaluation of slide mass samples presents a special problem in that their Atterberg Limit values may represent a mixture of stable and unstable (slide plane and erosional) sample types. The sampling strategy used to collect the slide mass samples was to "ensure that slide surfaces are accurately located and allows the competency of the materials beneath a landslide mass to be evaluated in-situ" (Nelson, 1985). Based on this strategy, the sample data would be biased towards unstable sample types. This is evident in the similarity between the values of the slide mass samples and the values of the erosional and slide plane 
samples. However, this sampling strategy does not preclude the inclusion of more "stable" sample types, which may account for the large standard deviation of the slide mass sample values, as well as the few anomalously low LL values.

Although the range of LL values does not permit mutualIy exclusive ranges to be established for stable and unstable sample types, threshold values can be estimated that indicate whether or not a soil or rock has a propensity to fail. All samples with LL values exceeding 67 represent failure planes, slide masses, or erosional scarps. Therefore, that value can serve as the critical value: the value above which failure occurs at a $100 \%$ frequency rate. The minimum LL value associated with unstable sample types (excluding slide mass samples) is 45 , which represents a conservative lower limit of stability. A more realistic lower limit would be 56, which represents the minimum LL value of slide plane samples. In light of this, samples with LL values between 45 and 67 indicate potentially unstable soil and rock types; special attention should be given to a soil or rock if its value exceeds 56 .

The relatively high mean $P I$ and LL values of slide plane, slide mass, and erosional sample types allow a number of generalizations to be made to explain this soil or rock type's tendency to fail. Voight (1973) and Kanji (1974) determined that residual shear strength decreases as the PI increases. Nelson (1985) found a similar relationship between both $\mathrm{PI}$ and $\mathrm{LL}$ with residual shear strength for 
samples collected from the study area. Accordingly, the higher mean PI and LL values associated with unstable sample types represent the lower residual shear strengths of those samples compared to samples from stable areas.

Residual Shear Strength. Samples collected from slide planes and erosional scarps exhibit a distinct difference in mean value of residual friction angle ( $\phi$ ) compared to samples collected from stable areas (Table 21). The mean $\phi$ value of slide plane samples is $8.6^{\circ}$ lower than the mean value of stable samples, representing a 53\% relative difference. Similarly, the mean value for erosional samples is $4.9^{\circ}$ lower than that of samples from stable areas, representing a $30 \%$ difference.

The slide plane samples have a closely-grouped range of $\phi$ values centered around the mean of $7.5^{\circ}$. All samples with a $\phi$ value less than $7.0^{\circ}$ represent unstable sample types; therefore this value can serve as the critical value. However, the relatively low minimum value of stable samples $\left(7.0^{\circ}\right)$ and the relatively high maximum value of erosional samples $\left(20.4^{\circ}\right)$ makes it difficult to establish the lower limit of stability. A very conservative value of $20^{\circ}$ can be set as the lower limit of stability, although a more realistic value of about $12^{\circ}$ (the mean $\phi$ value of erosional samples) is more appropriate. In any event, soils and rocks with $\phi$ values less than $20^{\circ}$ indicate potentially unstable 
soil or rock types; additional consideration should be given to a sample if its value approaches $12^{\circ}$.

Residual shear strength generally is considered to be the single most important parameter for slope stability analysis. Residual shear strength is essentially a frictional strength that defines the minimum shearing resistance along the failure surface of a landslide mass (Nelson, 1985).

\section{Inplace Dry Density and Natural Moisture Content.}

Samples collected from slide planes have a mean inplace dry density ( $\rho$ ) value that, on average, is $17 \mathrm{lb} / \mathrm{ft}^{3}$ lower than the mean $\rho$ value of slide mass samples (Table 22). This represents a $16 \%$ relative difference between the sample types. There is no notable difference in mean $\rho$ values between samples collected from the Arastradero and Stevens Creek lithofacies. The mean moisture-content value of slide plane samples is on average $13 \%$ higher than the mean value of slide mass samples (Table 23), representing a 63\% relative difference. The mean moisture-content value of slide plane samples from the Arastradero is 5\% higher than that of Stevens Creek samples, representing a $17 \%$ relative difference. It should be noted that other factors, such as seasonality and depth of sample collection, can influence the natural moisture content of a sample; therefore, the absolute values reported are not as significant as the trends they suggest. 
It is interesting to note that the slide plane and slide mass samples, which have similar mean Atterberg Limit values, have dissimilar $\rho$ and moisture-content values. This may be attributable to the different sampling strategies used by the various sources of data. A large portion of the $\rho$ and moisture content values were gathered from geotechnical reports where the sampling strategy was based on uniformly-spaced sampling intervals. This differs from the sampling strategy used to collect samples for Atterberg limit analysis, which focused specifically on identifying failure planes. Therefore, the Atterberg Limit values of slide mass samples would reflect a greater bias towards slide plane-type samples than the $\rho$ and moisture-content values of slide mass samples. However, the uniformly-spaced sampling strategy does not preclude the inclusion of slide plane-type samples, which may account for the small number of anomalously low $\rho$ values associated with the slide mass samples, which are approximately two standard deviations lower than the mean $\rho$ value.

The $\rho$ values of both the slide plane and slide mass samples exhibit closely-grouped ranges centered around their respective mean values. All samples with $\rho$ smaller than 90 lb/ $\mathrm{ft}^{3}$ represent slide planes; consequently, this value represents the critical value. The highest value associated with slide planes is $96 \mathrm{lb} / \mathrm{ft}^{3}$, which can be viewed as the lower limit of stability. Samples with $\rho$ values smaller than $96 \mathrm{lb} / \mathrm{ft}^{3}$ indicate that potentially unstable soils and rocks 
are present and special consideration should be given as their values approach $90 \mathrm{lb} / \mathrm{ft}^{3}$. The mean moisture-content values of the slide plane and slide mass samples form two distinct groups, with their ranges of values being tightly grouped around their respective means. The moisture-content value of $31 \%$ represents the critical value above which all soil and rock samples are associated with slide planes. The minimum value associated with slide plane samples is $24 \%$. Therefore, samples with moisture-content values exceeding $24 \%$ should be considered to represent potentially unstable soil or rock types. It should be kept in mind that because there are no $\rho$ or moisture-content data for samples collected from stable areas, the lower limit of stability is not as substantiated as those established for the other geotechnical properties.

The relatively low $\rho$ values and high moisture-content values of slide plane samples are characteristic of highly plastic clays containing smectite clay minerals. In fact, slide plane samples contain abundant smectite clay minerals compared to samples from stable areas (Table 26). Because of the physical and chemical characteristics of smectite, void ratios are high and the voids are filled with water. As a result, as the void ratio and water content increase, the inplace dry density decreases (Nelson, 1985). 
Percent Clay Content and Median Grain Size. Mean values of percent clay content and median grain size for samples from stable areas differ notably from the mean values of unstable sample types (Table 24). The mean percent clay content of slide plane and erosional samples are $13 \%$ higher than the mean value of samples collected from stable areas, representing a $41 \%$ relative difference. Based on this observation, it is not unexpected that the mean median grain size of slide plane and erosional samples are $53 \%$ and $36 \%$ (respectively) finer relative to the mean median grain size of samples collected from stable areas (Table 25).

Although the ranges of percent clay content and median grain size values do not permit mutually exclusive ranges to be established for stable and unstable sample types, critical values can be estimated that indicate whether or not a soil or rock is inclined to fail. All samples containing clay-sized particles in excess of $49 \%$ of their dry sample weight represent erosional scarps or failure planes; therefore, that value serves as the critical value. Samples containing less than 25\% clay-size particles were not observed to be associated with unstable soils or rocks; however, the lowest value associated with slide-plane samples (32\%) would make a more appropriate lower linit of stability. Soils containing clay-size particles between $32 \%$ and $49 \%$ indicate potentially unstable soil and rock types; special consideration should be given to a soil or 
rock if its value approaches $45 \%$ (the mean value of slide plane and erosional sample types).

All samples with median grain sizes finer than $.0021 \mathrm{~mm}$ represent unstable sample types, allowing this value to be set as the critical value. On the other hand, samples with a median grain size coarser than $.0078 \mathrm{~mm}$ were not associated with unstable sample types and therefore can represent the lower limit of stability. Therefore, soils with median grain sizes between $.0021 \mathrm{~mm}$ and $.0078 \mathrm{~mm}$ indicate potentially unstable soil and rock types; additional consideration should be given to a soil or rock if its median grain size is finer than $.0038 \mathrm{~mm}$ (the mean value of erosional samples).

The percent clay content and median grain size values of each sample type give some insight into important correlative properties. Nelson (1985) determined that, as the percent clay content increases, the residual shear strength decreases. It follows that the high values of clay content associated with unstable sample types (Table 24) translate into small residual shear strengths (Table 21) compared to samples from stable areas. The percent clay content and median grain size also give an indication of the soil's permeability. As the clay content increases and the median grain size decreases, the permeability generally decreases. As a result, a permeability contrast may exist along which a failure surface would tend to form. 
Clay Mineralogy. The wide range of relative abundance values and their high standard deviations from their means (Table 26) prohibits any definite conclusions to be made. The scatter of the values can be attributed to the semiquantitative approach used in determining the relative abundance of each clay type, where subjective decisions are made by the researcher in interpreting the $\mathrm{x}$-ray diffraction patterns. However, the values do allow a number of generalizations to be made pertaining to the clay-composition characteristics of the sample types.

Slide plane samples contain roughly $8 \%$ more smectite (montmorillonite) than samples from stable areas, representing a $46 \%$ relative difference. This value favorably compares to the relative difference of percent clay content between these sample types, which is $41 \%$. Indeed, the relative abundance of the three clay types in each sample category appears to be controlled by the percent clay content of each sample. Although the values fall within large ranges, the mean values of the clay types in Table 27 suggest that the ratio of the clay minerals in each sample type is fairly consistent. The proportion of kaolinite in the three sample types ranges from approximately $27 \%$ (erosional samples) to $36 \%$ (slide plane samples). Mean smectite content ranges from more than $53 \%$ (stable samples) to about $66 \%$ (erosional samples). The largest variation in clay proportion exists for the abundance of illite in the three sample categories. Samples from stable areas contain twice as much 
illite $(16 \%)$ as erosional samples ( $8 \%)$. However, this large variation does not represent a fundamental change in engineering characteristics of the soil samples because illite is present in such small quantities. Moreover, the geotechnical significance of illitic clay types is minor compared to montmorillonitic clay types (Trefethen, 1959).

Because the ratio of the clay minerals in each sample type is relatively constant, the additional information that can be gained from $x$-ray analysis does not warrant utilizing this costly and time-consuming process. The correlation between such index properties as Atterberg Limits and shear strength with expansive clay types can give an adequate indication of the relative abundance of these clays in a much more economical and time-efficient manner. For example, a relationship has been shown to exist between the abundance of montmorillonite (Tourtelot, 1962) and smectite (Nelson, 1985) and Liquid Limit. Both authors determined that as the LL value of a sample increases, the abundance of these expansive clay types also increases. Therefore, the higher LL values of the unstable sample types (Table 20) suggest that these samples contain relatively more expansive clay minerals than samples from stable areas. Residual shear strength also is correlated with clay composition. Samples with a $\phi$ value less than $11^{\circ}$ commonly contain abundant montmorillonitic minerals (smectite), whereas samples with higher $\phi$ values commonly have relatively more micaceous minerals (Kenny, 1967). In fact, Table 26 indicates that 
slide plane samples (mean $\phi=7.5^{\circ}$ ) and erosional samples (mean $\phi=11.2^{\circ}$ ) contain more smectite and less illite than samples collected from stable areas (mean $\phi=16.1^{\circ}$ ).

The relatively high proportion of smectite in each sample type has important implications for the stability of all earth materials within the study area. Montmorillonitic clay types have very weak intersheet bonding strengths, producing excellent cleavage. In addition, the open crystal structure allows water molecules to enter the lattice, causing it to expand to as much as 8-10 times its original thickness (c-axis dimension). In fact, some montmorillonitic clays can swell as much as $1600 \%$, whereas kaolinitic clays commonly swell less than $10 \%$ (Trefethen, 1959). It also has been observed that when a naturally swelled montmorillonite is dried only a small amount it will swell and slake immediately upon saturation (Grim, 1953). Therefore, because of the high ratio of smectite in all sample types, slope stability becomes increasingly threatened as the percentage of clay-sized particles increases.

\section{Structural Relationships}

The estimations of the presence of "day-lighting" failure planes in Appendix $F$ indicate that bedding-plane failures are not characteristic of landslides within the study area. The probability of "possible" day-lighting failure planes actually existing is relatively low, but still possible, with large errors in slope measurements 
being required in order for these values to fit within Hoek and Bray's (1974) criteria. The probability of day-lighting failure planes termed "doubtful" actually existing is remote. In fact, Figure 22 suggests that the distribution of landslides with respect to bedding attitude and slope inclination is random, with no correlation existing between structural relationships and landslide occurrence. Therefore, a mechanism other than bedding plane failure must be active within the study area.

Nelson (1985) suggested that most of the landslides within the study area were caused by the progressive shear failure of overconsolidated claystones. According to this theory, large horizontal stresses are created in the overconsolidated claystones as unloading of the overlying materials occurs. The horizontal stresses will then concentrate on discontinuities within the claystone mass. The discontinuities can represent oversteepened slopes, cut slope toes, or soft spots within the claystone. A progressive failure plane will then proceed up-slope from the discontinuity as local concentrations of shear strength exceed the peak shear strength of the material (Nelson, 1985). Although a bedding plane can act as the discontinuity along which progressive shear failure propagates, this mechanism can occur independently of bedding planes. Therefore, progressive shear failure provides an adequate explanation for the lack of correlation between structural relationships and landslide occurrence. 
Landslides within the study area have been associated with deep weathered zones on slopes and thick unconsolidated colluvial deposits (Cummings, 1968). Weathered zones on slopes tend to form parallel to the slope face, irrespective of bedding attitudes. The colluvial mantle is weak compared to the underlying unweathered material, and permeability contrasts between the two can lead to the formation of a failure plane. This mechanism of failure is favorable for shallow landslides and further explains the lack of association between structural relationships and landslide occurrence.

\section{Slope Form}

Uniform slopes, in both profile and plan view, are the most common slope form associated with landslides, occurring with frequencies of $57 \%$ and $49 \%$, respectively. Failures on convex slopes are the rarest, occurring at frequencies of $7 \%$ and $18 \%$. A high degree of association was noted between profile and plan slope forms, with uniform-uniform slopes observed at $35 \%$ of the landslide sites. Convex-concave and convex-convex associations were not noted for landslide events within the study area. Slope forms of Arastradero landslides exhibit more uniform geometries than stevens Creek failures, at the expense of concave forms. The largest discrepancy in slope form was noted between slopes adjacent to shallow and deep landslides. While both landslide types have similar proportions of uniform geometries, 
slopes adjacent to shallow landslides have more convex forms. Slopes adjacent to deep landslides exhibit a notably higher frequency of concave geometries.

Because the total areas of uniform, concave, and convex slopes were not determined for this study, it cannot be stated with certainty that uniform slopes are more susceptible to failure than other slope forms. However, Ritter (1986) has indicated that every slope profile (idealized) contains uniform, concave, and convex elements in nearly equal proportions. Convex slopes are most commonly encountered along the upper segment of slope profiles and represent areas of extensive soil creep and terrace formation. The central segment of slope profiles is typically uniform in geometry and is composed of the fall face and transportational midslope geomorphic units. Concave slopes are most commonly encountered along the lower segment of slope profiles and represent areas of redeposition of landslide materials.

Because the majority of slope forms associated with landslide events are uniform, this would empirically suggest that the landslides within the study area tend to form somewhere along the midslope areas of slope profiles. Indeed, when this observation is compared to the actual distribution of landslides in Plate 1 , the majority of landslides do form in that position, with relatively fewer slope failures occurring along the lower and upper slope segments. 
It should be noted that a number of variables can influence the observed relationship between slope form and landslide occurrence. If landslide masses have moved a significant distance down-slope from the scarp area, it is important to include the scarp in the mapping of the landslide. If only the landslide deposit is included in the mapping, the true form of the slope where the landslide initially occurred can be overlooked. Secondly, the amount of detail included in the construction of the slope profile can result in variations of the slope form associated with slope failures. For this study, because of the large scale of map used, a single slope segment was measured from the top of the scarp to the bottom of the landsiide deposit on the slope adjacent to the actual landslide event. More detailed maps and slope profile measurements may refine the relationship between slope form and landslide occurrence. 


\section{PRECIPITATION-INDUCED LANDSLIDES}

The relationships between precipitation and slope failure in the study area were investigated. For this portion of the study, two topics were addressed: 1) a brief investigation was conducted to determine the amount of precipitation typically required to induce slope failure and 2) characteristics commonly associated with precipitation-induced landslides were identified.

\section{Precipitation Values Required to Induce Slope Failures}

Each winter, a number of landslides occur within the study area that can be attributed to precipitation-induced failure (William Cole, personal communication, 1993). Since the early 1960's, significant structural damage has resulted from precipitation-induced landslides. Because the exact dates that the majority of the precipitation-induced failures were initiated are unknown, a general investigation was conducted to determine precipitation totals for rainfall seasons when a large number of damaging landslides occurred. Antecedent rainfall values and totals for individual storms and/or storm series were examined for four rainfall seasons to determine if the failure-promoting conditions observed by Mark and Newman (1988) were present. These authors suggested that landslides in the San Francisco Bay area commonly occur after pre-storm totals reached 250-380 mm (10-15 in) and storm totals reached $150-200 \mathrm{~mm}$ (6-8 in). 
The following sections describe the precipitation characteristics of the especially wet seasons of 1968-69, 1972-73, 1982-83, and 1992-93. Rainfall seasons are recorded between July 1 and June 30. The precipitation values used in this section represent values reported from the Los Gatos weather station. The Los Gatos station, located at an elevation of $111 \mathrm{~m}$ (365 ft) above mean sea level, is the closest station to the study area that provided continuous data for the period of study.

\section{8-69 Rainfall Season}

A total of 335 landslides were reported in the San Francisco Bay area during the especially wet winter of the 1968-69 rainfall season (Nilsen and others, 1979). From this total, eight landslides were reported to have caused structural damage to houses or roads within the study area. The following list summarizes some of the important rainfall characteristics of the 1968-69 season (National Climatic Data Center, 1968 and 1969).

- Season Total: $886 \mathrm{~mm}$ (34.89 in)

- Amount Above Average: $190 \mathrm{~mm}$ (7.46 in)

- Pre-January Total: $188 \mathrm{~mm}$ (7.39 in)

- December Total: $125 \mathrm{~mm}$ (4.90 in)

- Date $250 \mathrm{~mm}$ Accumulated: January 18, 1969

- Notable Storms: January 11-14: $47 \mathrm{~mm}$ (1.84 in) January $18-30: 274 \mathrm{~mm}$ (10.8 in) including January 19-21: $127 \mathrm{~mm}$ (5.00 in) 


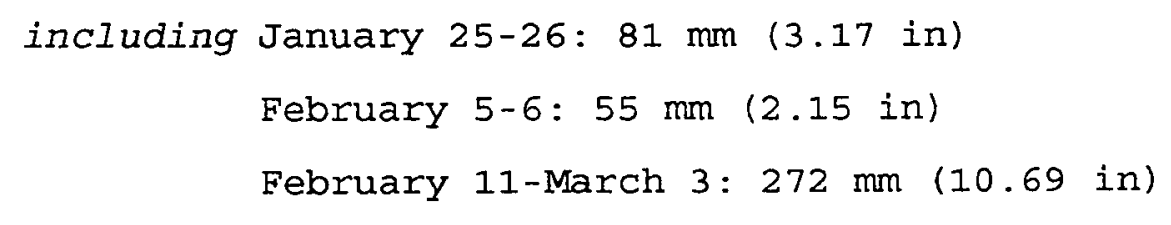

The rainfall data indicate that on January 18, 1969, the seasonal rainfall total reached the threshold value of $250 \mathrm{~mm}$. The following 13 consecutive days produced an additional $274 \mathrm{~mm}$ of precipitation, easily exceeding the 150-200 mm storm criteria suggested by Mark and Newman (1988). Similarly, two consecutive storms between February 11 and March 3, 1969, brought an additional $272 \mathrm{~mm}$ of precipitation, again exceeding the 150-200 mm threshold value.

\section{2-73 Rainfall Season}

A total of 411 landslides occurred in the San Francisco Bay area during the 1972-73 rainfall season (Nilsen and others, 1979). Records on file with the County of Santa Clara, as well as information reported by Nilsen and others (1979), indicate that at least five precipitation-induced landslides occurred in the study area during this season. The following list summarizes some of the important rainfall characteristics of the 1972-73 season (National Climatic Data Center, 1972 and 1973).

- Season Total: $891 \mathrm{~mm}$ (35.09 in)

- Above Average: $190 \mathrm{~mm}$ (6.98 in)

- Pre-January Total: $313 \mathrm{~mm}$ (12.31 in)

- December Total: $48 \mathrm{~mm}$ (1.90 in)

- Date $250 \mathrm{~mm}$ Accumulated: November 15, 1972 
- Notable Storms: January 8-19: $192 \mathrm{~mm}$ (7.56 in) January 29-February 14: $247 \mathrm{~mm}$ (9.67 in) February 24-28: $87 \mathrm{~mm}$ (3.42 in)

After accumulating $250 \mathrm{~mm}$ of precipitation in midNovember, 1972, the study area experienced relatively dry conditions until January 8, 1973, when $192 \mathrm{~mm}$ of precipitation fell in 12 consecutive days. Another series of storms between January 29 and February 14, 1973 brought an additional $247 \mathrm{~mm}$ of precipitation.

\section{2-83 Rainfall Season}

Numerous landslides within the study area resulted from the heavy precipitation that fell between January and April, 1983. Many of these landslides were documented in William Cotton and Associate's Preliminary Storm Damage Assessment, Winter 1982-93, Saratoga, California (1983). The following list summarizes some of the important rainfall characteristics of the 1982-83 season (National Climatic Data Center, 1982 and 1983).

- Season Total: $905 \mathrm{~mm}$ (35.61 in)

- Above Average: $321 \mathrm{~mm}$ (12.64 in)

- Pre-January Total: $249 \mathrm{~mm}$ (9.94 in)

- December Total: $100 \mathrm{~mm}$ (3.93 in)

- Date $250 \mathrm{~mm}$ Accumulated: January 16, 1983

- Notable Storms: January 16-30: $285 \mathrm{~mm}$ (11.2 in)

February 2-8: $63 \mathrm{~mm}$ (2.48 in)

February 12-18: $33 \mathrm{~mm}$ (1.30 in) 
February 23-March 7:222 mm (8.74 in)

March 10-13: $46 \mathrm{~mm}$ (1.80 in)

March 16-27: $81 \mathrm{~mm}$ (3.17 in)

April 18-30: $163 \mathrm{~mm}$ (6.40 in)

The 1982-83 season was characterized by a series of heavy storms punctuated by periods of lesser, but still significant, precipitation. The $250 \mathrm{~mm}$ threshold value was reached on January 16, 1983, the first of 15 consecutive days of rain that produced a total of $285 \mathrm{~mm}$ of precipitation. After two weak storm systems brought $96 \mathrm{~mm}$ of precipitation in the first half of February, 1983, $222 \mathrm{~mm}$ fell during 13 consecutive days between February 23 and March 7, 1983. A late-season storm in late April produced an additional $163 \mathrm{~mm}$.

\section{2-93 Rainfall Season}

During field investigations in March, 1993, four landslides were identified that were induced by the heavy rainfall that fell in January and February, 1993. The following list summarizes some of the important rainfall characteristics of the 1992-93 season (National Climatic Data Center, 1992 and 1993).

- Season Total: $762 \mathrm{~mm}(30.00 \mathrm{in})$

- Above Average: $157 \mathrm{~mm}$ (6.18 in)

- Pre-January Total: $190 \mathrm{~mm}$ (7.46 in)

- December Total: $163 \mathrm{~mm}$ (6.42 in)

- Date $250 \mathrm{~mm}$ Accumulated: January 7, 1993 
- Notable Storms: January 1: $54 \mathrm{~mm}$ (2.14 in)

$$
\begin{aligned}
& \text { January 5-22:220 mm (8.67 in) } \\
& \text { February 4-11: } 47 \mathrm{~mm}(1.83 \mathrm{~mm}) \\
& \text { February 16-26: } 155 \mathrm{~mm}(6.1 \mathrm{in})
\end{aligned}
$$

The precipitation data indicate that on January 7 , 1993, the $250 \mathrm{~mm}$ threshold value was reached for seasonal rainfall. This coincided with 18 consecutive days of measurable precipitation that produced a total of $220 \mathrm{~mm}$ of rain. Four days prior to that storm system, $54 \mathrm{~mm}$ of rain fell in a 24-hour period. An 11-day series of storms between February 16 and 26, 1993, produced an additional $155 \mathrm{~mm}$ of precipitation.

\section{Discussion}

With the exception of the 1972-73 season, each of the studied seasons reached the $250 \mathrm{~mm}$ threshold value in early to mid-January. The 30-year seasonal rainfall average of $650 \mathrm{~mm}(25.58 \mathrm{in})$ was exceeded in each of the four seasons by between 157 and $321 \mathrm{~mm}$. However, it should be noted that average seasonal precipitation within the study area exceeds the threshold value. This may partially account for the landslides that typically occur within the study area each winter. Therefore, it appears that the storm criterion of 150-200 mm is the principle factor in controlling the abnormally high occurrence of precipitation-induced landslides in certain seasons within the study area. Each of the four studied precipitation seasons had multiple storms producing 
an excess of $150 \mathrm{~mm}$ subsequent to the threshold accumulation of $250 \mathrm{~mm}$ of precipitation. Two such storm series occurred during the seasons of 1968-69, 1972-73, and 1992-93; three such series occurred during the 1982-83 season.

Further study of this topic may provide additional constraints on precipitation values required to induce slope failure within the study area. Campbell (1975) found that few landslides occur unless seasonal precipitation reaches $250 \mathrm{~mm}$ and storm intensity exceeds $6 \mathrm{~mm} / \mathrm{hr}$. It would be interesting to determine if this hourly intensity rate also applies to the study area and, if so, does it take precedence over the 150-200 mm storm value suggested by Mark and Newman (1988). Another point worth considering is to compare precipitation values required to reactivate, enlarge, or increase the rate of movement of existing landslides to values required to initiate new failures. Unfortunately, it is often difficult to determine the exact date of slope failure and equally difficult to obtain sufficiently detailed precipitation data pertaining to hourly intensity.

\section{Slope Characteristics of Precipitation-Induced Landslides}

Slope angle, slope aspect, and vegetation characteristics of slopes susceptible to precipitation-induced failure were investigated. For this portion of the study, eight mapped landslides within the study area were selected where the specific month or rainfall season when slope failure occurred was known (Plate 1). 


\section{Data Compilation and Manipulation}

The majority of the landslides used in this portion of the study were compiled from unpublished geotechnical reports. Reports indicating landslides induced by precipitation included Cotton and Associates (1983) and unpublished reports on file with the county of santa Clara. Two landslides initiated during the especially wet month of January, 1993, were brought to my attention by William Cole of Cotton and Associates (William Cole, personal communication, 1993). Two additional landslides were identified by the author during field observations in March, 1993. Failure of these slopes was estimated to have begun in late January, 1993, or early February, 1993.

After the landslides had been compiled onto the base map, they were digitized and manipulated following the procedures described in the "Regional Investigation" portion of this paper. The slope angle, slope aspect, and vegetation characteristics of precipitation-induced landslides were then evaluated. These relationships were determined using the same methodology used in the "Regional Investigation."

\section{Results}

Slope Angle and Precipitation-Induced Landslides. The greatest occurrence of precipitation-induced landslides is on slopes between $0^{\circ}$ and $15^{\circ}$ (Fig. 23). Other peak angles for precipitation-induced landslides occur at the 25-30 and 


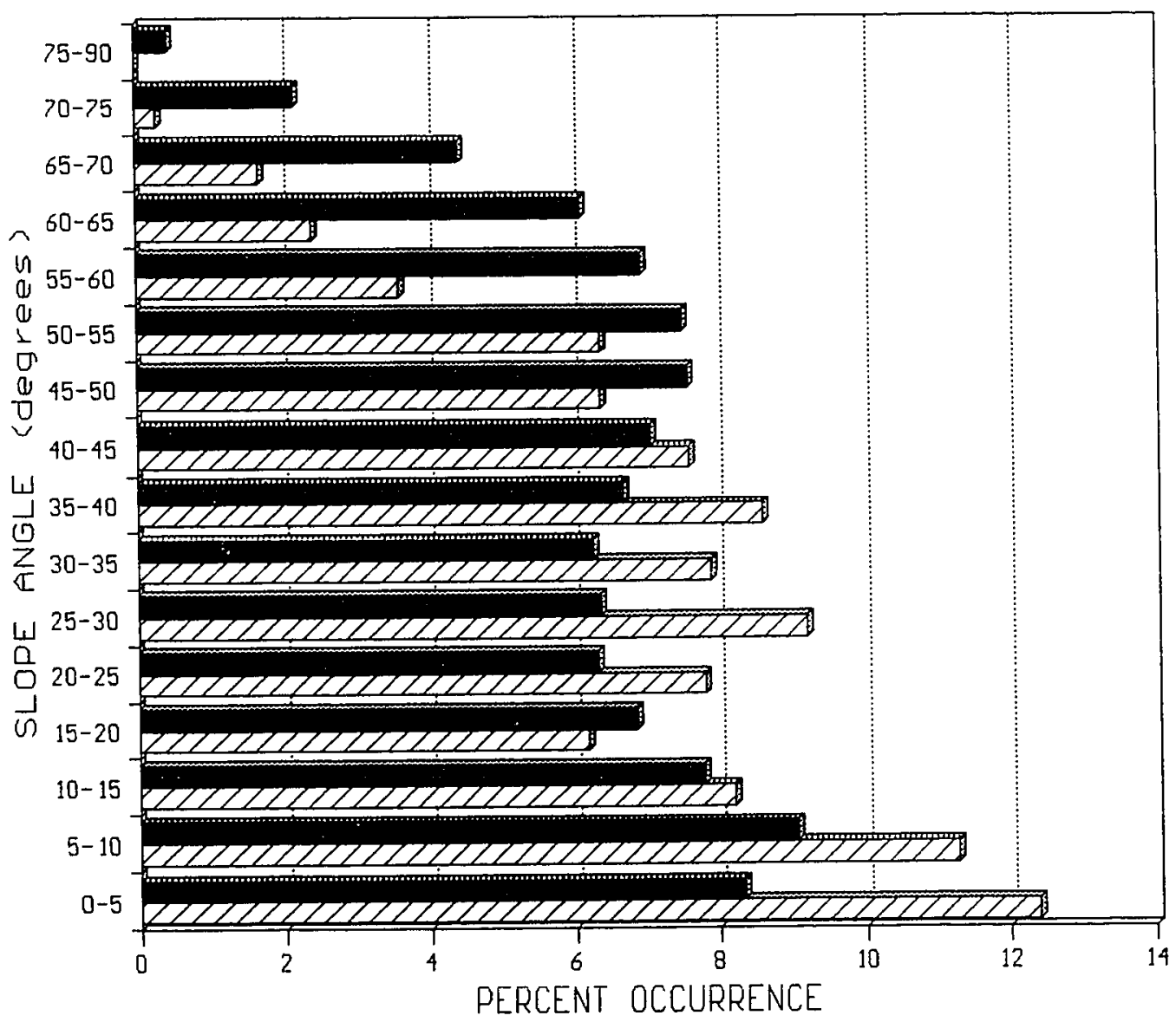

$$
\text { ZZA Rainfall-Induced All }
$$

Figure 23. Distribution of precipitation-induced landslides with respect to slope angle within the study area. Included in this figure is the distribution of all landslides within the study area. 
35-40 intervals. Precipitation-induced landslides were not noted to occur on slopes steeper than $75^{\circ}$.

In general, the frequency of precipitation-induced landslides on slopes gentler than $45^{\circ}$ is greater than the frequency of landslides overall, especially on slopes between $0-10^{\circ}$ and $25-30^{\circ}$. On slopes steeper than $45^{\circ}$, precipitation-induced landslides occur less frequently than the overall distribution of landslides would suggest, especially on slopes between 55-70\%. The frequency of precipitationinduced landslides on slopes between $15^{\circ}$ and $20^{\circ}$ is less than the frequency of landslides overall. It should be noted that the maximum variation in the occurrence of precipitation-induced landslides relative to the overall distribution of landslides is relatively small $( \pm 4 \%)$. This suggests that slope angle is not a significant factor in a slope's susceptibility to precipitation-induced failure.

\section{Slope Aspect and Precipitation-Induced Landslides.}

The majority of precipitation-induced landslides occurred on southeast- and east-facing slopes (Fig. 24). Nearly half (47\%) of the precipitation-induced landslides occurred on east-facing slopes and an additional 25\% occurred on southeast-facing slopes. Precipitation-induced landslides on west- and southwest-facing slopes are rare.

The frequency of precipitation-induced landslides on east- and southeast-facing slopes is greater than the frequency of all types of landslides. Precipitation-induced 


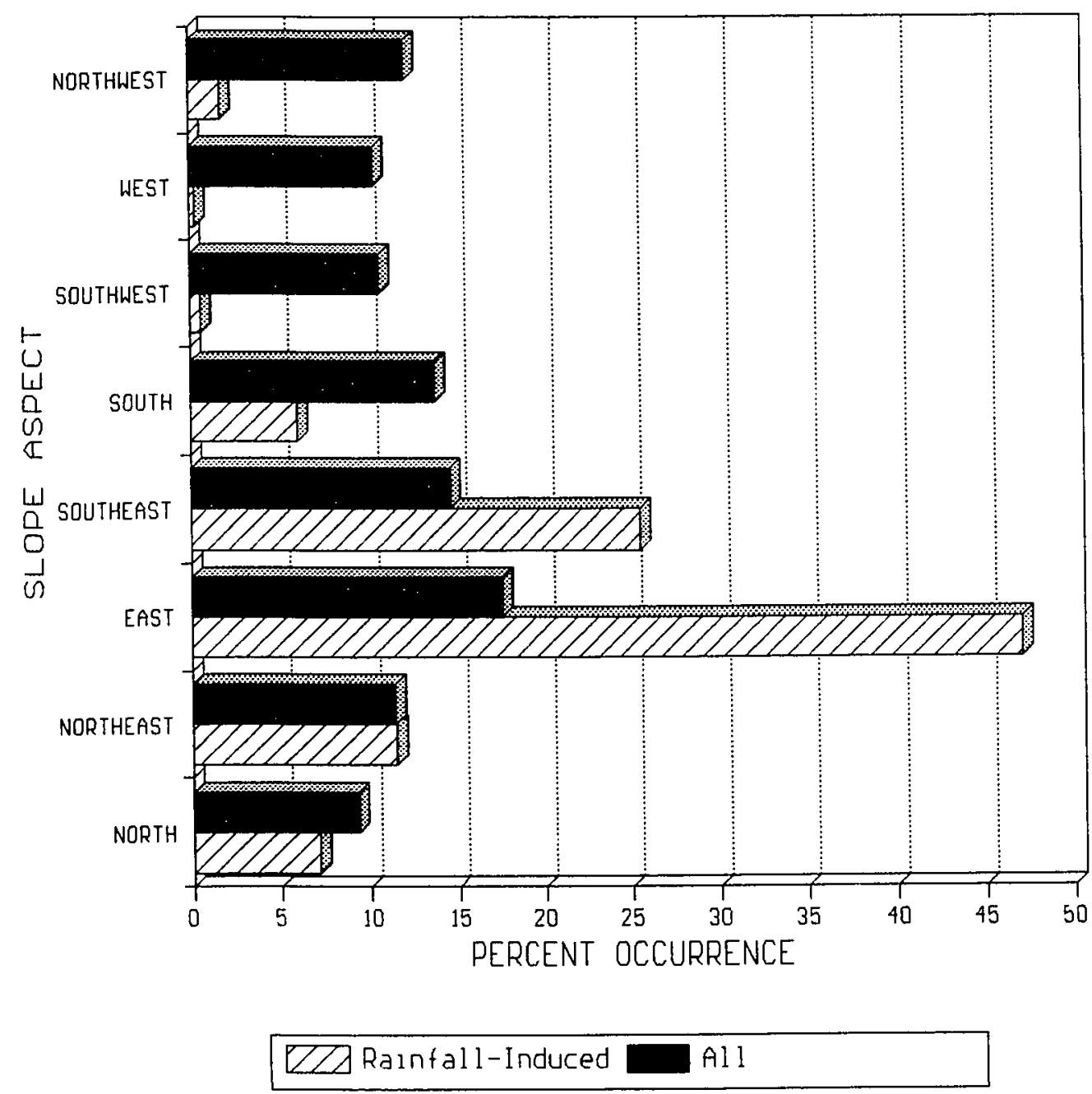

Figure 24. Distribution of precipitation-induced landslides with respect to slope aspect within the study area. Included in this figure is the distribution of all landslides within the study area. 
landslides on south-, southwest-, west-, and northwestfacing slopes occur less frequently than landslides of all types. The distribution of precipitation-induced landslides on north- and northeast-facing slopes is similar to the overall distribution of landslides on those aspects.

\section{Vegetation and Precipitation-Induced Landslides.}

Woodland slopes are the most susceptible to precipitationinduced failure, comprising $42 \%$ of the precipitation-induced landslides (Fig. 25). Grassland vegetation covers $25 \%$ of the precipitation-induced landslides. Precipitation-induced landslides were not noted to occur on terrain covered by scattered brushland/woodland or brushland.

The occurrences of precipitation-induced landslides on woodland and bare/residential slopes are greater than the overall occurrence of landslides on these slopes would predict. Agricultural land exhibits a slightly greater susceptibility to precipitation-induced failure than the distribution of all landslides would suggest. Grassland, scattered brushland/woodland, and brushland slopes are less susceptible to precipitation-induced failure than the overall distributions of landslides suggest.

\section{Interpretation of Results}

\section{Slope Angle and Precipitation-Induced Landslides.}

Figure 23 suggests that slope angle does not control the occurrence of precipitation-induced landslides. However, 


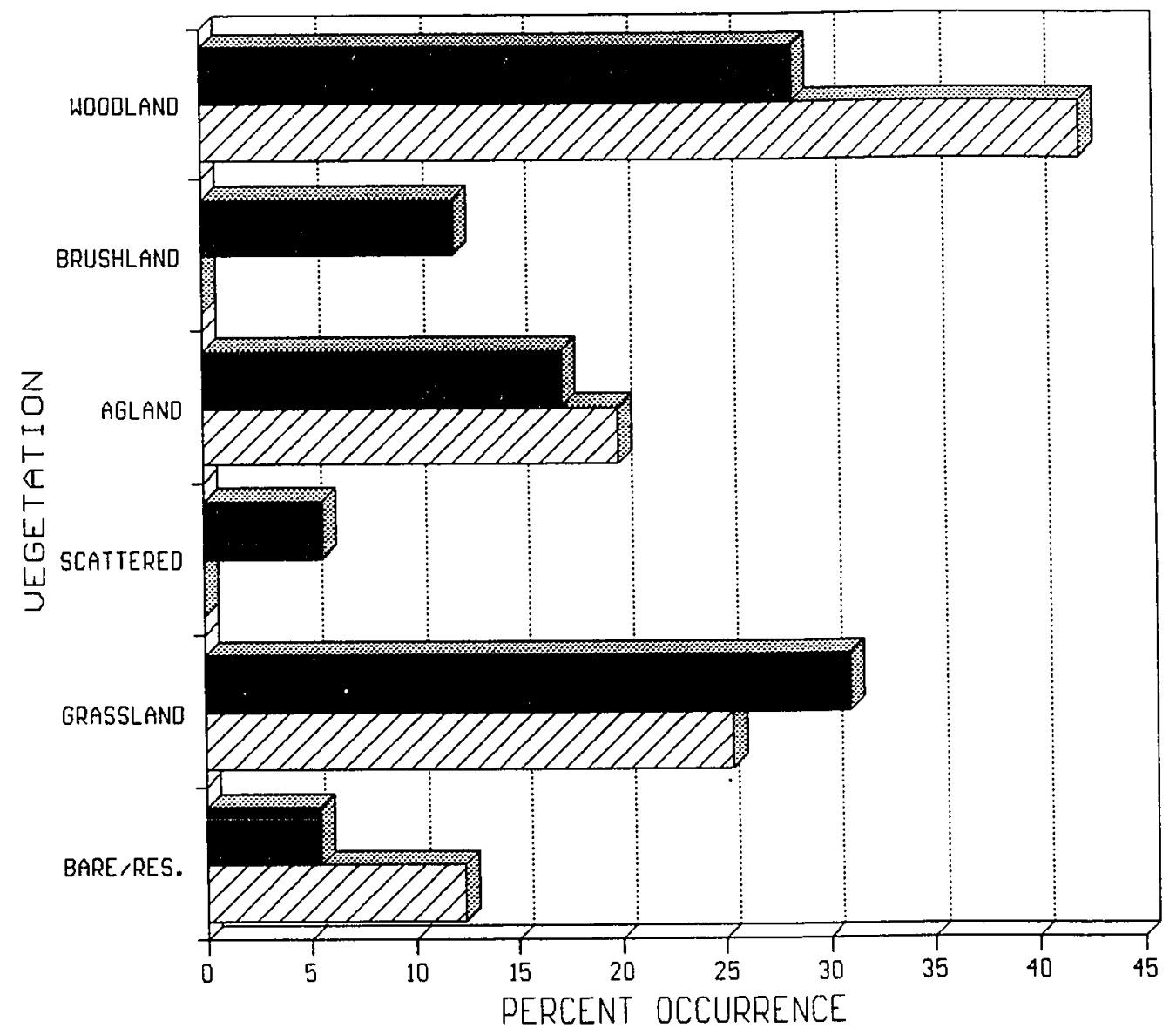

$$
\text { Z7A Rainfall-Induced All }
$$

Figure 25. Distribution of precipitation-induced landslides with respect to vegetation within the study area. Included in this figure is the distribution of all landslides within the study area. 
one observation does warrant comment: the increased occurrence of precipitation-induced landslides on slopes gentler than $45^{\circ}$ relative to the distribution of all landslides in that slope interval. As previously discussed, the steeper segments of slopes typically are covered by significantly less colluvium compared to the gentler slopes, which tend to have thicker mantles of material. With less colluvial material, the steeper slopes will tend to retain less moisture and will dry more rapidly than the thicker colluvial mantles on gentler slopes. The concentrated moisture on the shallower slopes results in increased overburden weight and decreased shear strength, increasing the likelihood of slope failure. Furthermore, where thin colluvium overlies weathered bedrock, the infiltration capacity of the material will be exceeded more readily and overland flow of the storm runoff will occur. This results in increased erosion downslope from the steeper terrains, which, within the study area, are generally slopes of lesser gradient.

Slope Aspect and Precipltation-Induced Landslides. The relationship between slope aspect and precipitation-induced landslides involves a number of complicating, interrelated factors. In general, landslides in the northern hemisphere tend to be more abundant on north- and east-facing slopes than on south- and west-facing slopes, because the southand west-facing slopes tend to dry out more quickly (Beatty, 1956). However, an added complication exists, because more 
vegetation typically grows on north- and east-facing slopes, which tends to minimize landslides by the anchoring action of the roots on the soil and the water-use characteristics of the vegetation.

As expected, east-facing slopes show a high susceptibility to precipitation-induced failure. Southeast-facing slopes, which generally contain more moisture than slopes of the other aspects, also are highly susceptible to precipitation-induced failure. The drier south-, southwest-, and west-facing slopes are less susceptible to precipitationinduced failures than the distribution of all landslides on those aspects would suggest. These drier slopes typically experience lower precipitation rates than northerly aspects because the majority of winter storms come from the northwest. However, north- and northwest-facing slopes, which would be expected to have relatively high moisture contents and precipitation rates, are both less susceptible to precipitation-induced failure than expected. The most evident explanation for this would be that the stabilizing effects of vegetation on these slopes minimizes the influence of the increased moisture.

Vegetation and Precipitation-Induced Landsildes. The greater occurrence of precipitation-induced landslides on bare/residential slopes is not unexpected. Because these slopes lack significant vegetal cover, they are subjected 
to high erosion and infiltration rates without the benefit of significant root strength or evapotranspiration.

Forest-covered slopes experience precipitation-induced failures at a frequency much higher than the frequency of landslides of all types. In general, forest vegetation is predicted to increase the stability of a slope because of its rooting strength and water-use characteristics. During seasons of average rainfall, forest-covered slopes can be expected to effectively remove or intercept excess water from the slopes. However, it is possible that many forestcovered slopes are marginally stable, remaining so by virtue of the root strength and water-use characteristics provided by the vegetation. In seasons of heavy precipitation the capacity of the vegetation to effectively remove water from the slopes is exceeded and the slopes become saturated. once the soil becomes saturated and the vegetation thoroughIy watered, the detrimental effects of the saturated soil exceeds any benefit from the greater rooting strength. However, it was noted that north- and northwest-facing slopes, which are primarily forest-covered, were relatively unaffected by heavy precipitation. From the available data, no explanation for this contradiction can be given.

The less frequent occurrence of precipitation-induced landslides on grass-covered slopes indicates that slope failures are more common on non-grassland slopes after all slopes have become saturated. This may result because grass-covered slopes become saturated sooner than forest- 
covered slopes and are susceptible to failure sooner than forested slopes. The majority of marginally stable grasscovered slopes may fail during seasons of average precipitation, as long as sufficient rainfall occurs to moisten slopes enough to cause instabilities. Consequently, during seasons of especially heavy rainfall, marginal slopes covered by vegetation typically considered more stable will be observed to fail more often. 


\section{CONCLUSIONS}

This study has shown the correlation between a number of factors and slope instability within the study area. Most of these factors, to some degree, form complex interrelationships that combine to affect slope stability. Table 33 summarizes the relative influence each factor exerts on slope stability.

Table 33. Summary of relative factor influence on slope stability. Symbols used: $M=$ major influence; $\mathrm{m}=$ minor influence; $S=$ slight influence; $N=$ no influence; ? = unknown influence; 1 = correlated with vegetation; $2=$ correlated with slope aspect; 3 = correlated with slope position; $4=$ correlated with slope form.

\begin{tabular}{|c|c|c|c|c|}
\hline \multirow{2}{*}{$\begin{array}{l}\text { EACTOR } \\
\text { Lithofacies }\end{array}$} & \multicolumn{4}{|c|}{ IANDSLIDES } \\
\hline & $\mathrm{N}$ & $\mathbf{N}$ & $\mathrm{N}$ & $S$ \\
\hline Slope Angle & $\mathrm{m}$ & $\mathrm{m}$ & m & $S$ \\
\hline Slope Aspect & MI & M1 & M1 & M1 \\
\hline Vegetation & M2 & M2 & $\mathrm{M} 2$ & M2 \\
\hline $\begin{array}{l}\text { Geotechnical } \\
\text { Properties }\end{array}$ & $?$ & ? & ? & M \\
\hline $\begin{array}{l}\text { Structural } \\
\text { Relationships }\end{array}$ & ? & $?$ & ? & $\mathbf{N}$ \\
\hline Slope Form & M3 & M3 & M3 & M3 \\
\hline Slope Position & M4 & M4 & M4 & M4 \\
\hline
\end{tabular}


Vegetation is the controlling factor within the study area. Grass-covered slopes exhibit twice the susceptibility to failure compared to forest- and brush-covered slopes. The greater stability of forest- and brush-covered slopes is attributable to their greater root strength and water-use characteristics. Shallow landslides tend to form on grasscovered slopes, which typically have shallow, poorly-developed root systems. Conversely, deep landslides tend to form on brush- and forest-covered slopes, which have deep, interlocking root networks.

Slope aspect is a critical stability parameter in that it controls the amount of moisture in a slope and, consequently, controls the distribution of vegetation. South-, east-, southeast-, southwest-, and west-facing slopes, which are primarily grass covered, are the most susceptible to failure within the study area. Conversely, northeast- and north-facing slopes, which are mostly wooded, are the most stable aspects. Shallow landslides tend to occur on the drier, grass-covered southerly and westerly slopes, whereas deep landslides occur on the wetter, forest-covered northerly and easterly slopes.

Slope angle appears to have little control in the distribution of landslides. In general, landslide occurrence is proportional to the distribution of slope angle, although slight trends are present. Shallow landslides tend to form on gentle slopes and deep landslides tend to form on moderate to steep slopes. 
All factors being equal, the Arastradero lithofacies appears to be slightly more susceptible to slope failure than the Stevens Creek lithofacies based solely on lithologic properties. However, the greater abundance of grassland vegetation within the Arastradero has resulted in a greater occurrence of landslides within this lithofacies.

Table 34 shows the relative influence of each factor subclass on slope stability. The Landslide Potential Map, based on the combined influence of the individual factors, can be used to identify areas that are more or less susceptible to instability.

Table 34. Relative ranking of factor subclasses based on their influence on slope stability.

\begin{tabular}{||c|c|c|c||}
\hline $\begin{array}{c}\text { Influence on } \\
\text { Stability }\end{array}$ & Vegetation & Aspect & Angle \\
\hline Stable & Bare/Resid. & East & $85-90^{\circ}$ \\
& Brushland & Northeast & $80-85^{\circ}$ \\
& Woodland & North & $0-10^{\circ}$ \\
& Scattered & Northwest & $70-80^{\circ}$ \\
& Agricultural & Southeast & $65-70^{\circ}$ \\
& Grassland & West & $60-65^{\circ}$ \\
& & South & $10-25^{\circ}$ \\
& & Southwest & $55-60^{\circ}$ \\
& & & $25-35^{\circ}$ \\
& & & $55-45^{\circ}$ \\
& & & $45-55^{\circ}$ \\
\hline
\end{tabular}


Samples collected from landslide scarps and failure planes exhibited noticeable differences in geotechnical properties compared to samples collected from areas unaffected by slope instability. Table 35 summarizes the ranges of values that constitute stable, potentially unstable, and unstable soil or rock types. These values are based on limited data and are not meant to represent definitive categories; however, the values can be used to evaluate whether a soil or rock may have a propensity to fail. Excluded from Table 35 are Plastic Limit and clay mineralogy. Plastic Limit values of stable, slide plane, slide mass, and erosional scarp samples are nearly indistinguishable. The ratio of kaolinite, illite, and smectite are similar for each sample type, with the variation in the clay mineral abundance reflecting the overall variation in percent clay content in each sample.

Bedding attitude in relation to slope inclination is not correlated with slope stability within the study area. An evaluation of bedrock orientation, direction of landslide movement, and slope angles for 57 landslides sites (Appendix F) showed that none of the landslides met Hoek and Bray's (1974) criteria for "day-lighting" failure planes. In fact, the data suggest that the distribution of landslides with respect to bedding attitude and slope inclination is random. This suggests that a mechanism other than bedding plane failure, such as progressive shear failure or failure within colluvial deposits, is dominant within the study area. 
Table 35. Summary of the range of geotechnical values for stable, potentially unstable, and unstable sample types.

\begin{tabular}{||l|c|c|c||}
\hline & stable & $\begin{array}{c}\text { potentially } \\
\text { unstable }\end{array}$ & unstable \\
\hline $\begin{array}{l}\text { Liquid Limit } \\
\text { (\% dry weight) }\end{array}$ & $<45$ & $45-66$ & $>66$ \\
\hline $\begin{array}{l}\text { Residual Phi Angle } \\
\text { (degrees) }\end{array}$ & $>20$ & $12-20$ & $<12$ \\
\hline $\begin{array}{l}\text { Inplace Dry Density } \\
\text { (pcf) }\end{array}$ & $>100$ & $90-100$ & $<90$ \\
\hline $\begin{array}{l}\text { Moisture Content } \\
\text { (\% dry weight) }\end{array}$ & $<24$ & $24-31$ & $>31$ \\
\hline $\begin{array}{l}\text { Median Grain Size } \\
\text { (mm) }\end{array}$ & $>.0078$ & $.0021-.0078$ & $<.0021$ \\
\hline $\begin{array}{l}\text { Clay Content } \\
\text { (\%) }\end{array}$ & $<25$ & $25-49$ & $>49$ \\
\hline
\end{tabular}

Typical slopes in the study area have convex upper segments, planar mid slopes, and concave lower parts. Landslides are more common along mid slopes and are rare on upper slopes.

During the especially wet rainfall seasons of 1968-69, 1972-73, 1982-83, and 1992-93, numerous landslides occurred within the study area. Precipitation data from these seasons indicate that the 30-year seasonal rainfall average was exceeded by 175 to $321 \mathrm{~mm}$. Each season experienced multiple storms that produced rainfall in excess of $150 \mathrm{~mm}$, the threshold value suggested by Mark and Newman (1988) required 
to initiate slope failure. Precipitation-induced landslides occurred more frequently on slopes gentler than $45^{\circ}$. This appears to be because the thicker colluvial deposits on gentle slopes tend to retain more moisture than the thinner deposits on steeper slopes. East-and southeast-facing slopes, which tend to retain moisture, exhibited a high susceptibility to precipitation-induced failure compared to the drier west- and southwest-facing slopes. However, soil moisture does not appear to be a dominant factor considering north-facing slopes, which typically are highly moisture retentive and exhibit a moderate decrease in susceptibility to precipitation-induced failure. Unfortunately, the relationship between slope aspect and vegetation does not adequately account for this discrepancy. Bare/residential slopes, which are subject to high erosion and infiltration rates, were highly susceptible to precipitation-induced failure. Forest-covered slopes also were observed to fail during seasons of heavy precipitation. This may result as the capacity of the vegetation to effectively remove the water from marginally stable slopes is exceeded. Grasscovered slopes tended to be less susceptible to failure during seasons of heavy rainfall than during average years. These slopes, which tend to become saturated sooner than forest- and brush-covered slopes, may be susceptible to precipitation-induced failure during seasons of lesser rainfall. 
The results of the "regional investigation" indicate the stability characteristics of the factors of geology, slope angle, slope aspect, and vegetation within the study area. Each factor has a unique influence of the stability of a slope. When these influences are combined, a better estimation can be made of a slope's susceptibility to failure. The Landslide Potential Map (Plate 3) can be used to estimate the relative stability of slopes within the study area. However, it should be kept in mind that, when slopes are modified from their current conditions, eithex by human activities or natural processes, the applicability of this map is diminished.

The results of the "site-specific investigation" provide data for the factors of geotechnical properties, slope form, and slope position that help identify areas of questionable stability. Threshold values of Atterberg Limits, residual shear strength, inplace dry density, moisture content, median grain size, and percent clay content have been established that indicate potentially unstable soil or rock types. Certain slope profiles and positions have also been identified that indicate suspect areas.

In years of heavy precipitation, many slopes that exhibit stable characteristics are observed to fail. These slopes probably represent marginally stable slopes that under average conditions will remain stable, but because of the destabilizing effects of the increased moisture content, the stabilizing properties are surpassed and the slope fails. 
The results of the "regional investigation" and "sitespecific investigation" indicate that characteristics of unstable slopes differ from those of stable slopes. When the Landslide Potential Map is used in conjunction with site-specific characteristics of slopes, an educated determination can be made as to the relative stability of a slope. Furthermore, special engineering techniques can be applied to slopes that are suspected to be susceptible to precipitation-induced failure to mitigate the detrimental effects of surface water and groundwater on those slopes. 


\section{REFERENCES CITED}

American Society for Testing and Materials, 1984, Section 4, construction, v. 04.08: Philadelphia, Pennsylvania, American Society for Testing and Materials, $830 \mathrm{p}$.

Anbalagan, R., 1991, Terrain evaluation and landslide hazard zonation for environmental regeneration and land use planning in mountainous terrain, in Bell, D.H., ed., Landslides, Proceedings of the 6th International Symposium, February 10-14, 1992, Christchurch: Rotterdam, A.A. Balkema Publishers, v. 2, p. 861-868.

Beatty, C.B., 1956, Landslides and slope exposure: Journal of Geology, v. 64, p. 70-73.

Bjerrum, L., and Simons, N.E., 1960, Comparison of shear strength characteristics of normally consolidated clays, in Research conference on shear strength of cohesive soils: Boulder, Colorado, American Society of Civil Engineers, p. 711-727.

Branner, J.C., Newsom, J.F., and Arnold, Ralph, 1909, Description of the Santa Cruz quadrangle, California: U.S. Geological Survey Atlas Folio 163, 12 p.

Brown, R.D., Jr., and Lee, W.H.K., 1971, Active faults and preliminary epicenters $(1969-1970)$ in the southern part of the San Francisco Bay region: U.S. Geological Survey Miscellaneous Field Studies Map MF-307, scale 1:62,500.

Brown, C.B., and Sheus, M.S., 1975, Effects of deforestation on slopes: Journal of the Geotechnical Engineering Division, American Society of Civil Engineers, no. 101, p. 147-165.

Campbell, R.H., 1975, Soil slips, debris flows, and rainstorms in the Santa Monica Mountains and vicinity, southern California: U.S. Geological Survey Professional Paper $851,51 \mathrm{p}$.

Carrara, A., Carratelli, P., and Merenda, L., 1977b, Computer-based data bank and statistical analysis of slope instability phenomena: Zeitschrift fuer Geomorphologie, N.F. 21, p. 189-221. 
Carrara, A., Catalano, E., Sorriso, V.M., Reali, C., Merenda, L., and Rizzo, V., 1977a, Landslide morphometry and typology in two zones, Calabria, Italy: International Association of Engineering Geology Bulletin, no. 16, p. 8-13.

Chang, S.C., 1992, The Simprecise mapping and evaluation system for engineering geological and landslide hazard zonation, in Bell, D.H., ed., Landslides, Proceedings of the 6th International Symposium, February 10-14, 1992, Christchurch: Rotterdam, A. A. Balkema Publishers, vol. 2, p. 905-910.

Chui, Glennda, 1994, "Geologists find buried danger," in San Jose Mercury News, February 21, 1994, p. 1A

Cleveland, G.B., 1971, Regional landslide prediction: California Division of Mines and Geology Open-File Report $72-23,33 \mathrm{p}$.

Cooper, J.G., 1894, On some Pliocene fresh-water fossils of California: California Academy of Science Proceedings, ser. 2, v. 4, p. 166-171.

Cotton, William, and Associates, 1980, Geologic hazards analysis of the upper Calabazas Creek watershed, Saratoga, California, unpublished geotechnical report for the City of Saratoga, Santa Clara County, California: Los Gatos, California, William Cotton and Associates, $53 \mathrm{p}$.

-..- 1983, Preliminary storm damage assessment, winter 198283, Saratoga, California, unpublished geotechnical report for the City of Saratoga, Santa Clara County, California: Los Gatos, California, William Cotton and Associates, $52 \mathrm{p}$.

Cummings, J.C., 1968, The Santa Clara Formation and possible post-Pliocene slip on the San Andreas fault in central California, in Dickinson, W.R., and Grantz, A., eds., Proceedings of conference on geologic problems of San Andreas fault system: Stanford, California, Stanford University Publications-Geological Sciences, v. XI, p. 191-207.

--1 1972, The Santa Clara Formation on the southern San Francisco Peninsula, in Unofficial progress report on the USGS Quaternary studies in the San Francisco Bay area: Guidebook for Friends of the Pleistocene, October $6-8,1972$, p. 3-10. 
DeCoster, Judith, 1979, Landslide deposits, their slope exposure and degree of slope in the area of Mt. Hamilton, California \{M.S. thesis\}: San Jose, California, San Jose State University, $43 \mathrm{p}$.

Dibblee, T.W., Jr., 1966, Geology of the Palo Alto quadrangle, Santa Clara and San Mateo counties, California: California Division of Mines and Geology map sheets 6 and 8 , scale $1: 62,500$.

Fleck, R.J., 1967, Structural significance of the contact between Franciscan and Cenozoic rocks, southern San Francisco Peninsula, California \{M.S. thesis\}: Stanford, California, Stanford University, $60 \mathrm{p}$.

Gonzalez de Vallejo, L., 1977, Engineering geology for urban planning and development with an example from Tenerife (Canary Islands): International Association of Engineering Geology Bulletin, no. 15, p. 37-43.

Gray, D.H., 1973, Effects of forest clear-cutting on the stability of natural slopes: results of field studies: Washington D.C., University of Michigan, National Science Foundation, 119 p.

Greenway, D.R., Vegetation and slope stability, 1987, in Anderson, M.G. and Richards, K.S., eds., Slope stability: New York, New York, John Wiley \& Sons Ltd., $648 \mathrm{p}$.

Grim, R.E., 1953, Clay mineralogy: New York, New York, McGraw-Hill, 384 p.

Hoek, E., and Bray, J., 1974, Rock Slope Engineering: The Institution of Mining and Metallurgy, London: London, Great Britain, Unwin Brothers Limited, 309 p.

Huma, I., and Radulescu, D., 1978, Automatic production of thematic maps of slope stability: International Association of Engineering Geology Bulletin, no. 17, p. 95-99.

Kardos, L.T., Vlasoff, P.I., and Twiss, S.N., 1943, Factors contributing to landslides in the palouse region: Soil Science Society of America Proceedings, vol. 8, p. 437-440.

Kanji, M.A., 1974, The relationship between drained friction angles and Atterberg Limits of natural soils:

Geotechnique, v. 24, p. 671-674. 
Kenney, T.C., 1967, The influence of mineral composition on the residual strength of natural soils, in Proceedings of the Geotechnical Conference: Norwegian Geotechnical Institute, Oslo, Norway, v. 1, p. 123-129.

Lo, K.Y., 1962, Shear strength properties of a sample of volcanic materials of the valiey of Mexico: Geotechnique, v. 12 , p. 303-318.

Mark, R.K., and Newman, E.B., 1988, Landslides, floods, and marine effects of the storm of January $3-5,1982$, in the San Francisco Bay region, California: U.S. Geological Survey Professional Paper 1434, p. 17-26.

McLaughlin, R.J., 1974, The Sargent-Berrocal fault zone and its relation to the San Andreas fault system in the southern San Francisco Bay region and Santa Clara Valley, California: Journal of Research, U.S. Geological Survey, v. 2, p. 593-598.

National Climatic Data Center, 1968, Climatological dataCalifornia: Ashville, North Carolina, U.S. Department of Commerce, National Oceanic and Atmospheric Administration (NOAA), National Climatic Data Center, v. 72 .

--- 1969, Climatological data-California: Ashville, North Carolina, U.S. Department of Commerce, NOAA, National Climatic Data Center, v. 73.

---- 1972, Climatological data-California: Ashville, North Carolina, U.S. Department of Commerce, NOAA, National Climatic Data Center, v. 76.

-.-- 1973, Climatological data-California: Ashville, North Carolina, U.S. Department of Commerce, NOAA, National Climatic Data Center, v. 77.

-.--1982, Climatological data-California: Ashville, North Carolina, U.S. Department of Commerce, NOAA, National Climatic Data Center, v. 86.

-.--1983, Climatological data-California: Ashville, North Carolina, U.S. Department of Commerce, NOAA, National Climatic Data Center, v. 87.

-.-- 1992, Climatological data-California: Ashville, North Carolina, U.S. Department of Commerce, NOAA, National Climatic Data Center, v. 96. 
---- 1993, Climatological data-California: Ashville, North Carolina, U.S. Department of Commerce, NOAA, National Climatic Data Center, v. 97.

Nelson, J.L., 1985, Geotechnical and geologic properties of the Santa Clara Formation claystone, Saratoga foothills, Santa Clara County, California \{M.S. thesis\}: San Jose, California, San Jose State University, 120 p.

Nilsen, T.H., Wright, R.H., Vlasic, T.C., and Sprangle, W., 1979, Relative slope stability and land-use planning in the San Francisco Bay region, California: U.S. Geological Survey Professional Paper 944.

Orris, G.J., 1979, A quantitative investigation of landslides' in a portion of the Santa Clara Formation, Santa Clara County, California \{M.S. thesis\}: San Jose, California, San Jose State University, $80 \mathrm{p}$.

Prandini, L., Guidicini, G., Bottura, J.A., Poncano, W.L., and santos, A.R., 1977, Behaviour of the vegetation in slope stability: a critical review: Bulletin of the International Association of Engineering Geology, no. 15, p. $51-55$.

Putnam, W.C., and Sharp, R.P., 1940, Landslides and earth flows near Ventura, California: Geographical Review, v. 30, p. 591-600.

Rantz, 1971, Mean annual precipitation and precipitation depth-duration-frequency data for the San Francisco Bay region, California: U.S. Geological Survey HUD San Francisco Bay Region Environment and Resources Planning Study Basic Data Contribution 32, $23 \mathrm{p}$.

Radbruch, D.H., and Crowther, K.C., 1973, Map showing areas of estimated relative amounts of landslides in

California: U.S. Geological Survey Miscellaneous Investigation Series Map I-747, scale 1:500,000, 36 p.

Radbruch-Hall, D.H., and Varnes, D.J., 1976, Landslides cause and effect: International Association of Engineering Geology Bulletin, no. 14, p. 205-216.

Reneau, S.I., Dietrich, W.E., Donahue, D.J., Jull, A.J.T., and Rubin, M., 1990, Late Quaternary history of colluvial deposition and erosion in hollows, central California Coast Ranges: Geological Society of America Bulletin, v. 102, p. 969-982. 
Rib, H.T., and Liang, Ta, 1978, Recognition and identification, in Schuster, R.L. and Krizek, R.J., eds., Landslides: analysis and control: Washington, D.C., National Academy of Sciences, Transportation Research Board Special Report 176, p. 34-80.

Ritter, D.F., 1986, Process geomorphology (2nd edition): Dubuque, Iowa, W.C. Brown Publishers, 579 p.

Rogers, T.H., and Armstrong, C.F., 1973, Environmental geologic analysis of the Santa Cruz Mountain study area and Monte Bello Ridge Mountain study area, County of Santa Clara, California: California Division of Mines and Geology Preliminary Report 17, 118 p.

San Jose Mercury News, 1993, "Area Rainfall": San Jose Mercury News, February 19, 1993, p. 1B.

Soil Conservation Service, 1941, Soil Survey, Santa Clara Area, California: U.S. Department of Agriculture, Soil Conservation Service Soil Survey, Series 1941, no. 17.

1968, Soils of Santa Clara County: U.S. Department of Agriculture, Soil Conservation Service Soil Survey, 227 p.

Sorg, D.H., and McLaughlin, R.J., 1975, Geologic map of the Sargent-Berrocal fault zone between Los Gatos and Los Altos Hills, Santa Clara County, California: U.S. Geological Survey Miscellaneous Field Studies Map MF643, scale 1:24,000.

Terratech Inc., 1985, Slope instability potential map of the lower saratoga foothills, unpublished geotechnical report for the City of Saratoga, Santa Clara County, California: San Jose, California, Terratech, Inc., scale 1:7200.

Tourtelot, H.A., 1962, Preliminary investigation of the geologic setting and chemical composition of the Pierre Shale, Great Plains region: U.S. Geological Survey Professional Paper 390, 74 p.

Trefethen, J.M., 1959, Geology for engineers (2nd edition): New Jersey, D. Van Nostrand Company, Inc., 632 p.

Vanderhurst, W.L., 1981, The Santa Clara Formation and orogenesis of Monte Bello Ridge, Northwest Santa Clara County, California \{M.s thesis\}: San Jose, California, San Jose State University, $114 \mathrm{p}$. 
Varnes, D.J., 1978, Slope movement types and processes, in Schuster, R.L. and Krizek, R.J., eds., Landslides: analysis and control: Washington, D.C., National Academy of Sciences, Transportation Research Board Special Report 176, p. 12-33.

Voight, B., 1973, Correlation between Atterberg plasticity limits and residual shear strength of natural soils: Geotechnique, v. 23, p. 265-267. 
Appendix A. Atterberg Limit values for 64 samples. Asterisk $(*)$ denotes samples collected from the Arastradero lithofacies; all other samples were collected from the Stevens Creek lithofacies.

\begin{tabular}{|c|c|c|c|c|}
\hline & Liquid Limit & Plastic Limit & Plasticity & Index \\
\hline \multirow[t]{14}{*}{ stable } & 51 & 26 & 25 & \\
\hline & 49 & 19 & 30 & \\
\hline & 62 & 23 & 39 & \\
\hline & 42 & 21 & 21 & \\
\hline & 54 & 22 & 32 & \\
\hline & 65 & 36 & 29 & \\
\hline & 50 & 18 & 32 & \\
\hline & 55 & 17 & 38 & \\
\hline & 41 & 17 & 24 & \\
\hline & 65 & 19 & 46 & \\
\hline & 67 & 23 & 44 & \\
\hline & $53 *$ & $20 *$ & $33 *$ & \\
\hline & $48 *$ & $17 *$ & $31 *$ & \\
\hline & $51 *$ & $20 *$ & $31 *$ & \\
\hline \multirow[t]{9}{*}{ slide plane } & 64 & 17 & 47 & \\
\hline & 70 & 24 & 46 & \\
\hline & 82 & 22 & 60 & \\
\hline & 70 & 25 & 45 & \\
\hline & 56 & 23 & 33 & \\
\hline & 59 & 24 & 35 & \\
\hline & 68 & 17 & 51 & \\
\hline & 70 & 23 & 47 & \\
\hline & 73 & 20 & 53 & \\
\hline \multirow[t]{8}{*}{ slide mass } & 68 & 26 & 42 & \\
\hline & 49 & 22 & 27 & \\
\hline & 104 & 28 & 76 & \\
\hline & 59 & 17 & 42 & \\
\hline & 63 & 22 & 41 & \\
\hline & 107 & 30 & 77 & \\
\hline & 88 & 29 & 59 & \\
\hline & $66 *$ & $2 \cdot 2 *$ & $44 *$ & \\
\hline
\end{tabular}


Appendix A continued.

Liquid Limit Plastic Limit Plasticity Index

\begin{tabular}{|c|c|c|c|}
\hline \multirow[t]{25}{*}{ slide mass } & $62 \star$ & $26 *$ & $36 *$ \\
\hline & $63 *$ & $23 *$ & $40 *$ \\
\hline & $66 *$ & $22 *$ & 44 * \\
\hline & $65^{\star}$ & $26 *$ & $39 *$ \\
\hline & $41 *$ & $22 *$ & 19 * \\
\hline & $54 *$ & $22 \star$ & $32 *$ \\
\hline & 57 * & 21 * & $36 *$ \\
\hline & $55^{*}$ & $21 *$ & $34 *$ \\
\hline & $65 *$ & $24 *$ & $41 *$ \\
\hline & $82 *$ & $31 *$ & $51 *$ \\
\hline & $59 *$ & $22 *$ & $37 *$ \\
\hline & $54 *$ & $23 \star$ & $31 *$ \\
\hline & $66 *$ & 19 * & 47 * \\
\hline & $71 \star$ & $27 *$ & $44^{\star}$ \\
\hline & $43^{*}$ & $17 *$ & $26^{*}$ \\
\hline & $76 *$ & $40 *$ & $36 *$ \\
\hline & $53 *$ & $23 *$ & $30 *$ \\
\hline & $42 *$ & $19 *$ & 23 * \\
\hline & $72 *$ & $23 *$ & $49 *$ \\
\hline & $59 \star$ & $23 *$ & 36 * \\
\hline & $59 *$ & $25 *$ & $34 *$ \\
\hline & $78^{*}$ & $22 *$ & 56 * \\
\hline & $82 *$ & $31 *$ & $51 *$ \\
\hline & $65 *$ & $20 *$ & $45^{*}$ \\
\hline & $65 *$ & $18 *$ & $47 \star$ \\
\hline \multirow[t]{8}{*}{ erosional } & 45 & 21 & 24 \\
\hline & 58 & 23 & 35 \\
\hline & 88 & 20 & 68 \\
\hline & 50 & 23 & 27 \\
\hline & 85 & 23 & 62 \\
\hline & 47 & 17 & 30 \\
\hline & 59 & 21 & 38 \\
\hline & $86^{*}$ & 29 * & $57 *$ \\
\hline
\end{tabular}




\section{APPENDIX B. RESIDUAL FRICTION ANGLE VALUES}

Appendix B. Residual friction angle values for 19 samples. Asterisk (*) denotes sample collected from the Arastradero lithofacies; all other samples were collected from the Stevens Creek lithofacies.

Residual Friction Angle

stable

24.5

12.3

16.5

7.0

$20.0 *$

slide planes

8.5

7.0

8.0

7.0

8.3

5.0

6.2

7.3

8.0

9.5

erosional

20.4

6.0

6.0

12.5 


\section{APPENDIX C. INPLACE DRY DENSITY AND MOISTURE CONTENT VALUES}

Appendix C. Inplace dry density and moisture content values for 107 samples. Asterisk (*) denotes samples collected from the Arastradero lithofacies; all other samples were collected from the Stevens Creek Iithofacies. pcf $=$ pounds per cubic foot.

\begin{tabular}{cc} 
Inplace Dry Density & $\begin{array}{c}\text { Natural Moisture Content } \\
\text { (pcf) }\end{array}$ \\
\hline
\end{tabular}

$\begin{array}{llc}\text { slide plane } & 89 & 33.3 \\ 86 & 31.3 \\ 90 & 32.7 \\ 90 & 29.1 \\ 96 & 24.0 \\ 88 & 32.3 \\ 90 & 30 \\ 91 \star & 33 \text { * } \\ 82 \star & 37 \text { * } & 35 \\ 87 \star & 34 \text { * } & \\ \text { slide mass } & 86 & 21 \\ & 109 & 23 \\ 111 & 26 \\ 101 & 22 \\ 103 & 23 \\ 105 & 16 \\ 106 & 22 \\ 105 & 19 \\ 108 & 15 \\ 114 & 21 \\ 106 & 22 \\ 104 & 26 \\ 101 & 18 \\ 108 & 23 \\ 102 & 17 \\ 111 & 23 \\ 104 & 23 \\ 104 & \end{array}$


Appendix C continued.

Inplace Dry Density Natural Moisture Content (pCf) (\% dry weight)

slide mass

111

16

106

17

108

22

108

22

107

20

90

12

110

16

100

22

107

16

104

14

100

22

115

18

99

103

23

98

24

109

25

108

20

111

21

102

18

108

23

115

20

18

105

22

112

17

97

27

100

26

115

16

108

19

102 *

19 *

111*

18*

110 *

17*

113 *

16 *

109*

19 *

106*

102 *

19 *

20 * 
Appendix C continued.

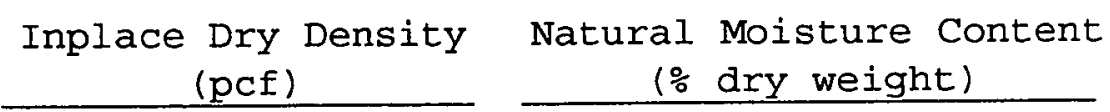

\begin{tabular}{|c|c|c|}
\hline slide mass & 103 * & 20 * \\
\hline & $107 *$ & 22 * \\
\hline & $96 *$ & $28 *$ \\
\hline & $103 *$ & 20 * \\
\hline & $100 *$ & 22 * \\
\hline & $101 *$ & $20 *$ \\
\hline & 122 * & $10 *$ \\
\hline & $107 *$ & 22 * \\
\hline & $99 *$ & 21 * \\
\hline & $93 *$ & 29 * \\
\hline & $102 *$ & $23 *$ \\
\hline & $108 *$ & $20 *$ \\
\hline & $97 *$ & $26 *$ \\
\hline & $92 *$ & $31 *$ \\
\hline & $88 *$ & $31 *$ \\
\hline & 104 * & 22 * \\
\hline & $108 *$ & 20 * \\
\hline & $97 *$ & 28 * \\
\hline & $106^{\star}$ & 20 * \\
\hline & $111 *$ & $19 *$ \\
\hline & $107 *$ & $21 *$ \\
\hline & $109 *$ & 17 * \\
\hline & $105^{*}$ & 22 * \\
\hline & $102 *$ & 21 * \\
\hline & $113 *$ & 18 * \\
\hline & $99 *$ & 26 * \\
\hline & $99 *$ & $21 *$ \\
\hline & $98 *$ & $25 *$ \\
\hline & $100 *$ & 24 * \\
\hline & $107 *$ & 19 * \\
\hline & $103 *$ & 19 * \\
\hline & $104 *$ & $22 \star$ \\
\hline & $94 *$ & $25 *$ \\
\hline & $96 *$ & $25 *$ \\
\hline
\end{tabular}


Appendix C continued. Inplace Dry Density
(pcf) $\quad \frac{\begin{array}{r}\text { Natural Moisture Content } \\ (\% \text { dry weight })\end{array}}{}$

slide mass

117 *

15 *

113*

16 *

108 *

16 *

110 *

112 *

16 *

18 *

107 *

115 *

117 *

119 *

11 *

16 *

$11 *$

$11 *$

106 *

$16 *$

109 *

18 * 


\section{APPENDIX D. MEDIAN GRAIN SIZE AND PERCENT CLAY CONTENT VALUES}

Appendix D. Median grain size and percent clay content values of 30 samples. Asterisk (*) denotes samples collected from the Arastradero lithofacies; all other samples were collected from the stevens Creek lithofacies. Clay is defines as particles finer than 2 microns $(.002 \mathrm{~mm})$.

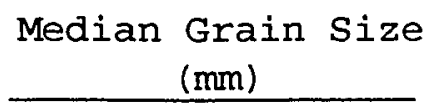

stable

slide plane

0.0017

$\begin{array}{ll}0.0043 & 35 \\ 0.0040 & 36 \\ 0.0160 & 18 \\ 0.0049 & 33 \\ 0.0060 & 22 \\ 0.0046 & 36 \\ 0.0049 & 39 \\ 0.0061 & 33 \\ 0.0021 & 49 \\ 0.0065 & 28 \\ 0.0059 * & 29 \star \\ 0.0050 \star & 31 \star \\ 0.0067 * & 22 \star\end{array}$

52

0.0023

47

0.0036

40

0.0034

40

0.0048

32

50

53

0.0018

32

$0.0012 \quad 56$

erosional

0.0057

25

0.0031

40

0.0005

70

0.0062 
Appendix D continued.

\begin{tabular}{ccc} 
& $\begin{array}{c}\text { Median Grain Size } \\
(\mathrm{mm})\end{array}$ & $\begin{array}{c}\text { Clay Content } \\
(\%)\end{array}$ \\
\cline { 2 - 3 } & & 70 \\
erosional & 0.0010 & 30 \\
0.0078 & 35 \\
0.0045 & $60 *$ \\
$0.0014^{\star}$ &
\end{tabular}




\section{APPENDIX E. CLAY MINERALOGY}

Appendix E. Clay mineralogy of 30 samples. Values represent percent of sample weight. Asterisk (*) denotes samples collected from the Arastradero lithofacies; all other samples were collected from the Stevens Creek lithofacies.

\begin{tabular}{lcc}
$\begin{array}{c}\text { Kaolinite } \\
(\% \text { of sample) }\end{array}$ & $\begin{array}{c}\text { Illite } \\
(\% \text { of sample) }\end{array}$ \\
\hline
\end{tabular}

stable

slide plane

23.4
26.3
2.4
11.2
10.2
18.0
22.3
11.8
20.2

erosional

16.1
10.8
4.0
11.2
0.0
30.4
1.1
11.0
14.2
8.4
$9.6 *$
$11.5 *$
$5.9 *$

23.4

26.3

.2

10.2

18.0

22.3

20.2

9.8
16.0
28.0
3.6
30.8
0.9
1.1
$16.7 \star$

3. 8

3.6

1.4

7.0

0.0

12.7

17.0

8.8

3.9

8.2

1. 7 *

$4.0 *$

$2.0 *$

3.1

5.2

1.5

1.6

5.2

6.0

5.3

2.9

10.1

1.2

4.5

7.0

3.9

10.5

1.2

0.0

3.2 *
15.0

21.6

12.8

14.8

21.3

2.9

20.9

13.2

30.9

11.3

17.4 *

15.6 *

$13.8 *$

25.5

16.0

37.0

24.0

16.5

26.0

25.5

17.2

26.3

13.7

19.6

35.0

20.4

28.0

28.0

35.0

40.0 * 


\section{APPENDIX F. STRUCTURAL RELATIONSHIP DATA}

Appendix F. Bedrock orientation, slope geometry, and structural relationship data for 57 landslides.

\begin{tabular}{|c|c|c|c|c|c|c|}
\hline $\begin{array}{l}\text { Bedrock } \\
\text { Orient. }\end{array}$ & $\begin{array}{l}\text { Slope } \\
\text { Dir. }\end{array}$ & $\begin{array}{l}\text { Slope } \\
\text { Angle }\end{array}$ & $\begin{array}{l}\text { Angle fr. } \\
\text { Parallel } \\
\end{array}$ & $\begin{array}{l}\text { Dip } \\
\text { Dif. }\end{array}$ & $\begin{array}{l}\text { Slope } \\
\text { Type } \\
\end{array}$ & $\begin{array}{c}\text { Intersect } \\
\text { Plane } \\
\end{array}$ \\
\hline N35W50E & $\mathrm{N} 41 \mathrm{E}$ & 11 & 14 & 39 & dip & Doubtful \\
\hline N32W50E & $\mathrm{N} 14 \mathrm{~W}$ & 15 & 72 & 35 & dip & No \\
\hline N43W40E & SO1W & 8 & 46 & 48 & anti & No \\
\hline N36W50E & N9OE & 12 & 36 & 38 & dip & No \\
\hline N02W55E & $\mathrm{N} 11 \mathrm{~W}$ & 15 & 81 & 70 & anti & No \\
\hline N46W30E & S4IE & 18 & 85 & 48 & anti & No \\
\hline N43E30S & N61W & 14 & 14 & 44 & anti & No \\
\hline NS3OE & S81E & 11 & 9 & 19 & dip & Possible \\
\hline N30W4 8E & $\mathrm{N} 11 \mathrm{~W}$ & 13 & 71 & 35 & dip & No \\
\hline $\mathrm{N} 12 \mathrm{~W} 45 \mathrm{E}$ & S83E & 17 & 19 & 28 & dip & DoubtfuI \\
\hline $\mathrm{N} 15 \mathrm{~W} 20 \mathrm{E}$ & $S 48 W$ & 16 & 27 & 36 & anti & No \\
\hline N72W53N & S75W & 12 & 57 & 65 & anti & No \\
\hline N2 OW65E & S02W & 14 & 68 & 79 & anti & No \\
\hline N32W32E & $\mathrm{N} 14 \mathrm{E}$ & 15 & 44 & 17 & dip & No \\
\hline N35W40E & N3OE & 22 & 25 & 18 & dip & Doubtful \\
\hline N23W35E & N21W & 22 & 88 & 13 & dip & No \\
\hline N35W30W & N05W & 13 & 60 & 43 & $\operatorname{anti}$ & No \\
\hline N33W55E & $\mathrm{S} 32 \mathrm{E}$ & 13 & 89 & 68 & anti & No \\
\hline $\mathrm{N} 43 \mathrm{~W} 40 \mathrm{E}$ & S42W & 14 & 5 & 54 & $\operatorname{ant} i$ & No \\
\hline N57W10N & S46W & 24 & 13 & 34 & anti & No \\
\hline N24W25E & S19W & 10 & 47 & 35 & anti & No \\
\hline $\mathrm{N} 18 \mathrm{~W} 35 \mathrm{E}$ & $S 87 E$ & 10 & 21 & 25 & dip & Doubtful \\
\hline N36W15W & S59E & 23 & 67 & 38 & anti & No \\
\hline N52W38S & N81E & 23 & 43 & 61 & anti & No \\
\hline N32W2 OW & S17E & 28 & 75 & -8 & dip & No \\
\hline N37W30S & $\mathrm{N} 22 \mathrm{~W}$ & 18 & 75 & 48 & anti & No \\
\hline N19E20E & $S 34 E$ & 22 & 37 & -2 & dip & DoubtfuI \\
\hline $\mathrm{N} 24 \mathrm{E} 25 \mathrm{E}$ & NS & 24 & 66 & 1 & dip & No \\
\hline N31E30E & $S 22 W$ & 20 & 81 & 10 & dip & No \\
\hline N26E35E & $\mathrm{N} 2 \mathrm{OE}$ & 16 & 84 & 51 & anti & No \\
\hline N88E45S & N5OW & 22 & 48 & 67 & anti & No \\
\hline N89E20S & S50E & 21 & 49 & -1 & dip & No \\
\hline N82E35S & $S 23 E$ & 21 & 15 & 14 & dip & Possible \\
\hline
\end{tabular}


Appendix F continued.

\begin{tabular}{|c|c|c|c|c|c|c|}
\hline $\begin{array}{l}\text { Bedrock } \\
\text { Orient. }\end{array}$ & $\begin{array}{l}\text { Slope } \\
\text { Dir. }\end{array}$ & $\begin{array}{l}\text { Slope } \\
\text { Angle }\end{array}$ & $\begin{array}{l}\text { Angle fr. } \\
\text { Parallel } \\
\end{array}$ & $\begin{array}{l}\text { Dip } \\
\text { Dif. }\end{array}$ & $\begin{array}{l}\text { Slope } \\
\text { Type }\end{array}$ & $\begin{array}{c}\text { Intersect } \\
\text { Plane } \\
\end{array}$ \\
\hline N31W4 OW & N58W & 28 & 63 & 12 & dip & No \\
\hline N35W30W & N71E & 17 & 16 & 47 & $\operatorname{anti}$ & No \\
\hline N3 3W2 OW & N73E & 30 & 16 & 50 & anti & No \\
\hline N33W2 OW & N1OW & 24 & 67 & 44 & $\operatorname{ant} i$ & No \\
\hline N33W55E & S25W & 28 & 32 & 83 & anti & No \\
\hline N48W2 5E & S75E & 13 & 63 & 12 & dip & No \\
\hline N29W2 OE & S3OE & 8 & 89 & 12 & dip & No \\
\hline N03E30E & S11W & 26 & 82 & 56 & anti & No \\
\hline N03E3OE & S11W & 20 & 82 & 50 & anti & No \\
\hline N45W34W & N79E & 14 & 34 & 48 & anti & No \\
\hline N22W35E & S53E & 16 & 59 & 19 & dip & No \\
\hline N43E45S & $S 28 E$ & 17 & 19 & 28 & dip & Doubtful \\
\hline N46W30E & S15W & 17 & 29 & 47 & anti & No \\
\hline N44W3OE & N35E & 12 & 11 & 18 & dip & Possible \\
\hline $\mathrm{N} 18 \mathrm{E} 43 \mathrm{E}$ & $\mathrm{N} 12 \mathrm{~W}$ & 18 & 60 & 61 & anti & No \\
\hline N29W35E & N55E & 15 & 6 & 20 & dip & Possible \\
\hline N3OW2OE & S50W & 15 & 10 & 35 & anti & No \\
\hline N28W5OE & S28W & 27 & 34 & 77 & anti & No \\
\hline $\mathrm{N} 13 W 40 \mathrm{E}$ & S74W & 13 & 3 & 53 & anti & No \\
\hline No $8 W 45 E$ & N2OW & 10 & 78 & 55 & anti & No \\
\hline N46W30E & $\mathrm{N} 10 \mathrm{E}$ & 21 & 34 & 9 & dip & Doubtful \\
\hline N46W22E & N50W & 16 & 86 & 38 & anti & No \\
\hline N24W36E & S2OE & 19 & 86 & 55 & anti & No \\
\hline N54E24W & NS & 15 & 36 & 9 & dip & No \\
\hline
\end{tabular}




\section{PLEASE NOTE:}

Oversize maps and charts are filmed in sections in the following manner:

\section{LEFT TO RIGHT, TOP TO BOTTOM, WITH SMALL OVERLAPS}

The following map or chart has been refilmed in its entirety at the end of this dissertation (not available on microfiche). A xerographic reproduction has been provided for paper copies and is inserted into the inside of the back cover.

Black and white photographic prints (17" $\times 23$ ") are available for an additional charge. 



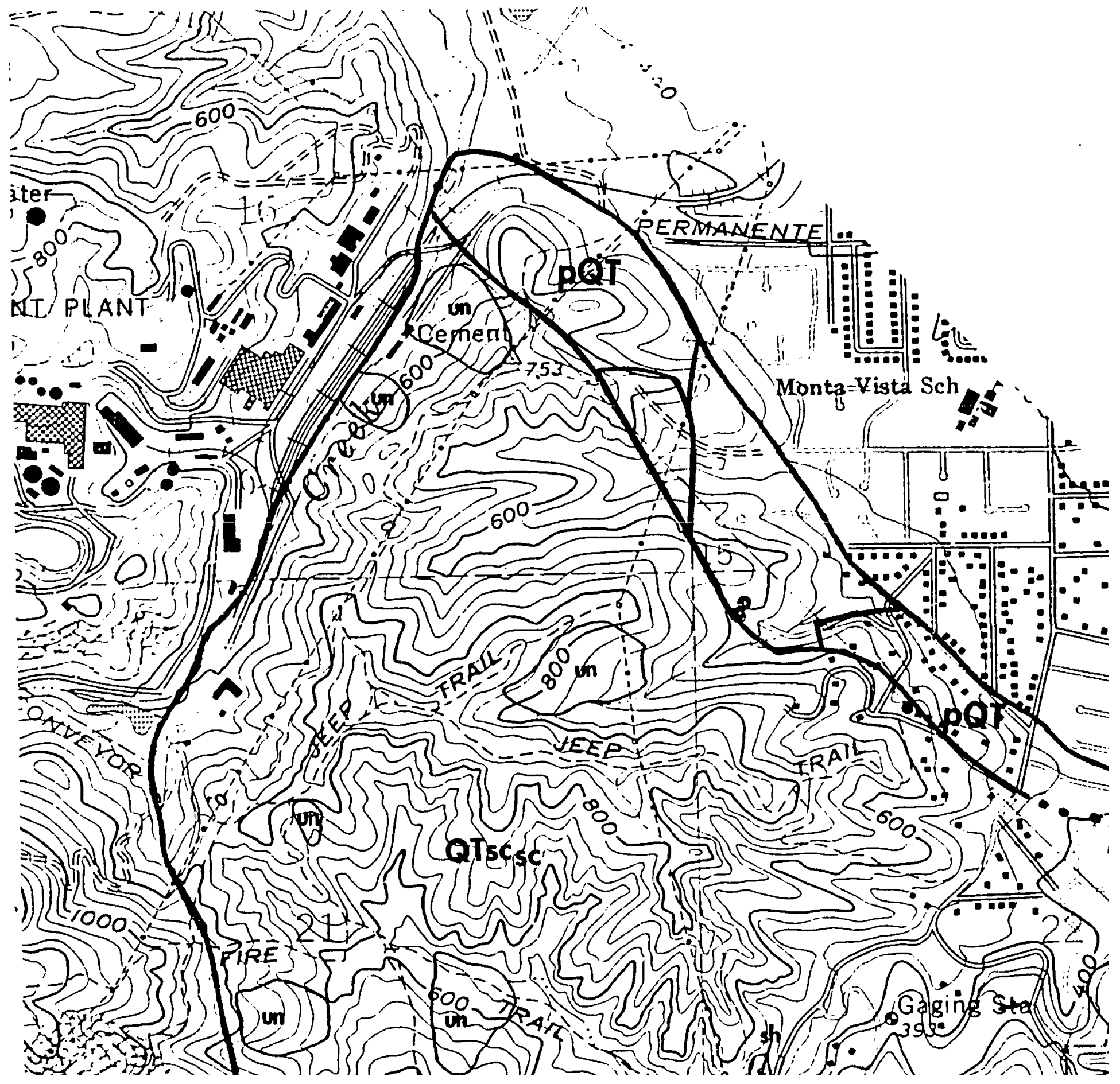




\section{BEDROCK GEOLOGY AND LANDSLIDE IISTRIBUTION MAP OF A PORTION OF THE 'UPERTINO 7.5' QUADRANGLE, CALIFORNIA}

(B. Reddig, 1994)

EXPLAI

BEDROCK GEOLOGY

$\mathrm{QTsc}_{\text {sc }}$

\section{$\operatorname{QTsc}_{\mathbf{a}}$}

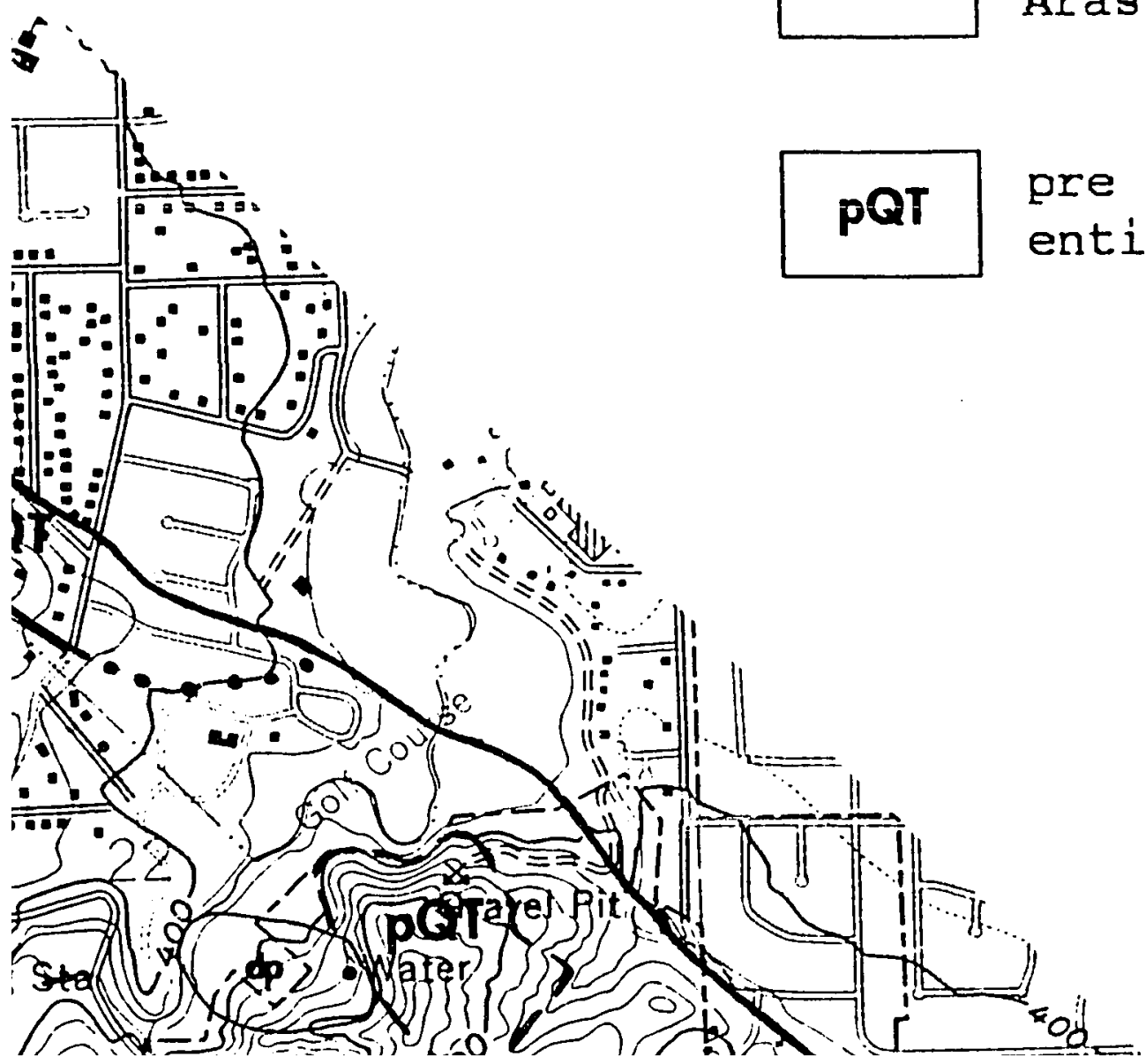

Santa Clara Formaticn Stevens Creek Lithofacies

Santa Clara Formation Arastradero Lithofacies 


\section{EXPLANATION}

¿OLOGY

a Formation
eek Lithofacies

a Formation

o Lithofacies

'leistocene undifferiedimentary rocks
LANDSLIDES

sh
$(<3 \mathrm{~m})$

$d p \quad \begin{aligned} & \text { Deep } \\ & (>3 \mathrm{~m})\end{aligned}$

un Undifferentiated

\section{SYMBOLS}

Stratigraphic contact: dashed where approximated, dotted where concealed

Fault contact: dashed where approximated, dotted where concealed 


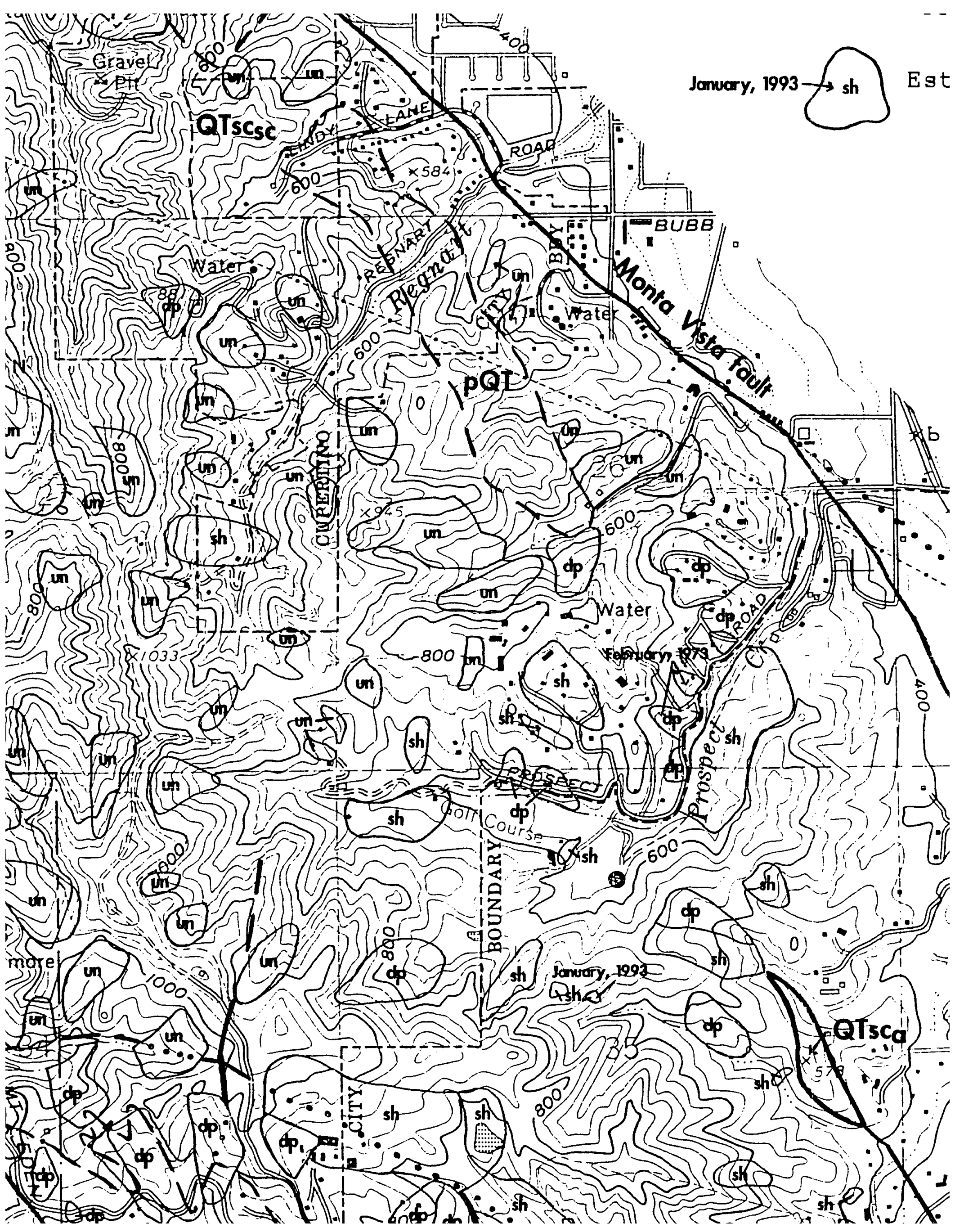


$-\rightarrow$ approximated, dotted where concealed January, 1993 sh Estimated time of slope failure

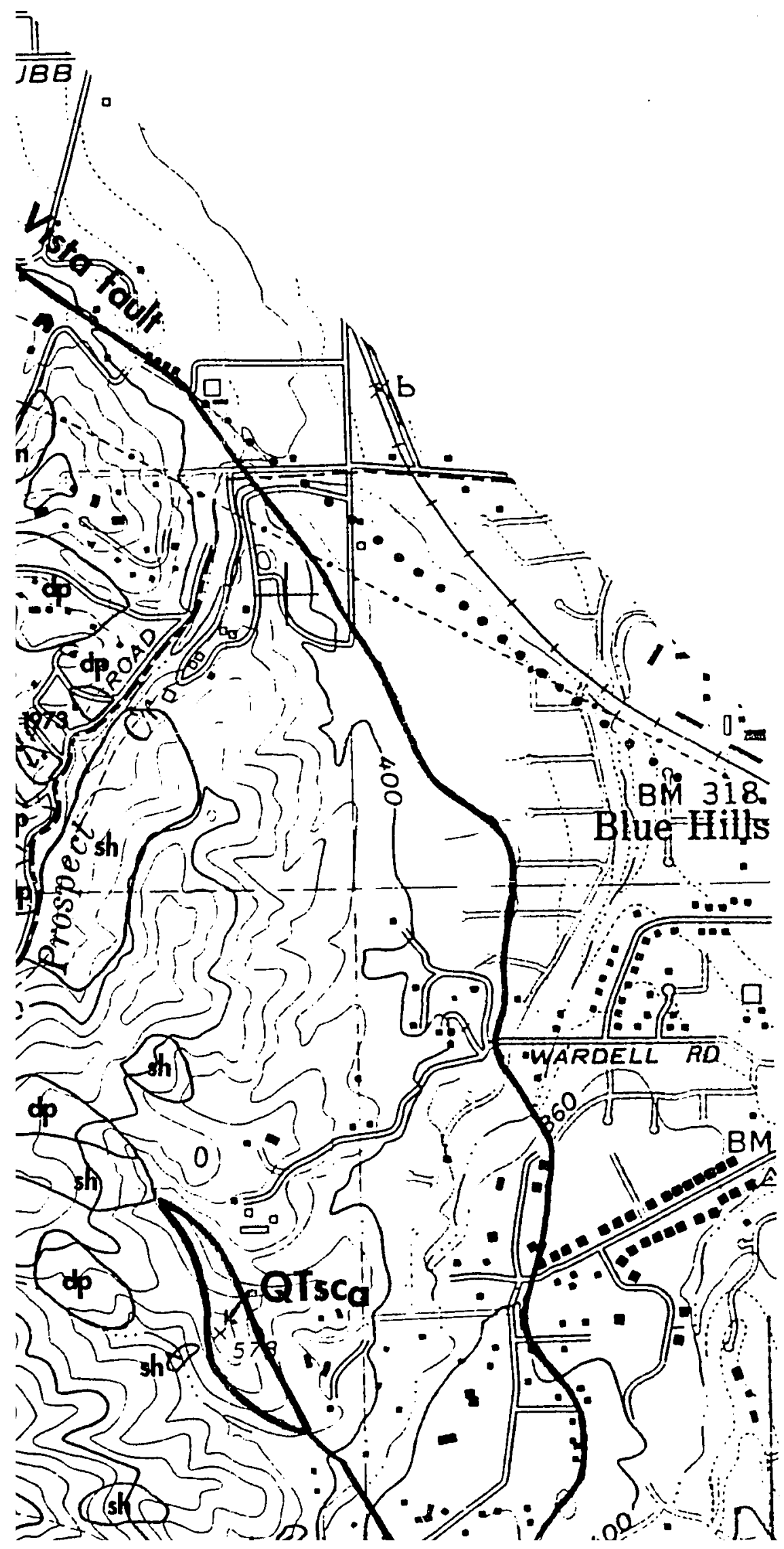




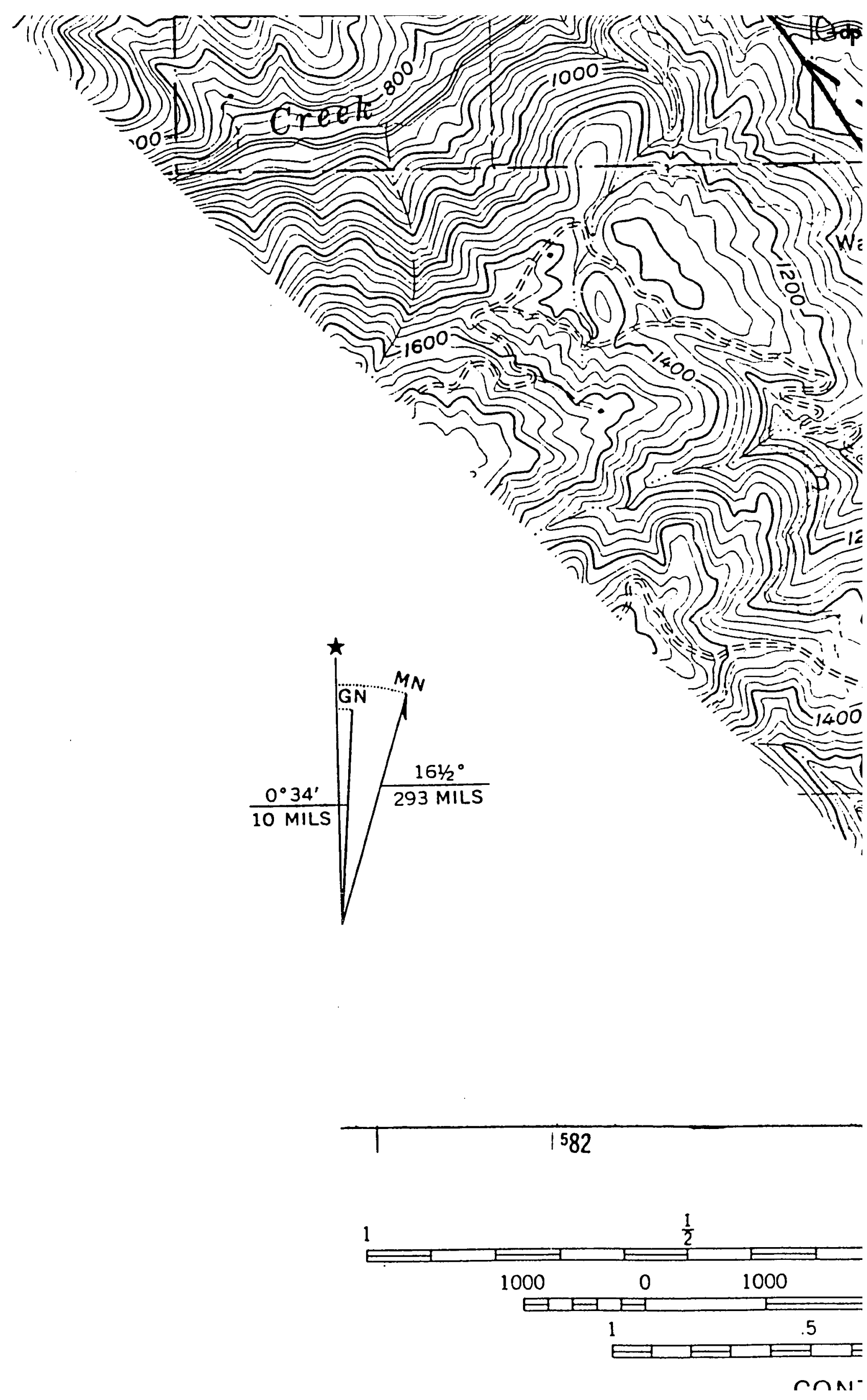




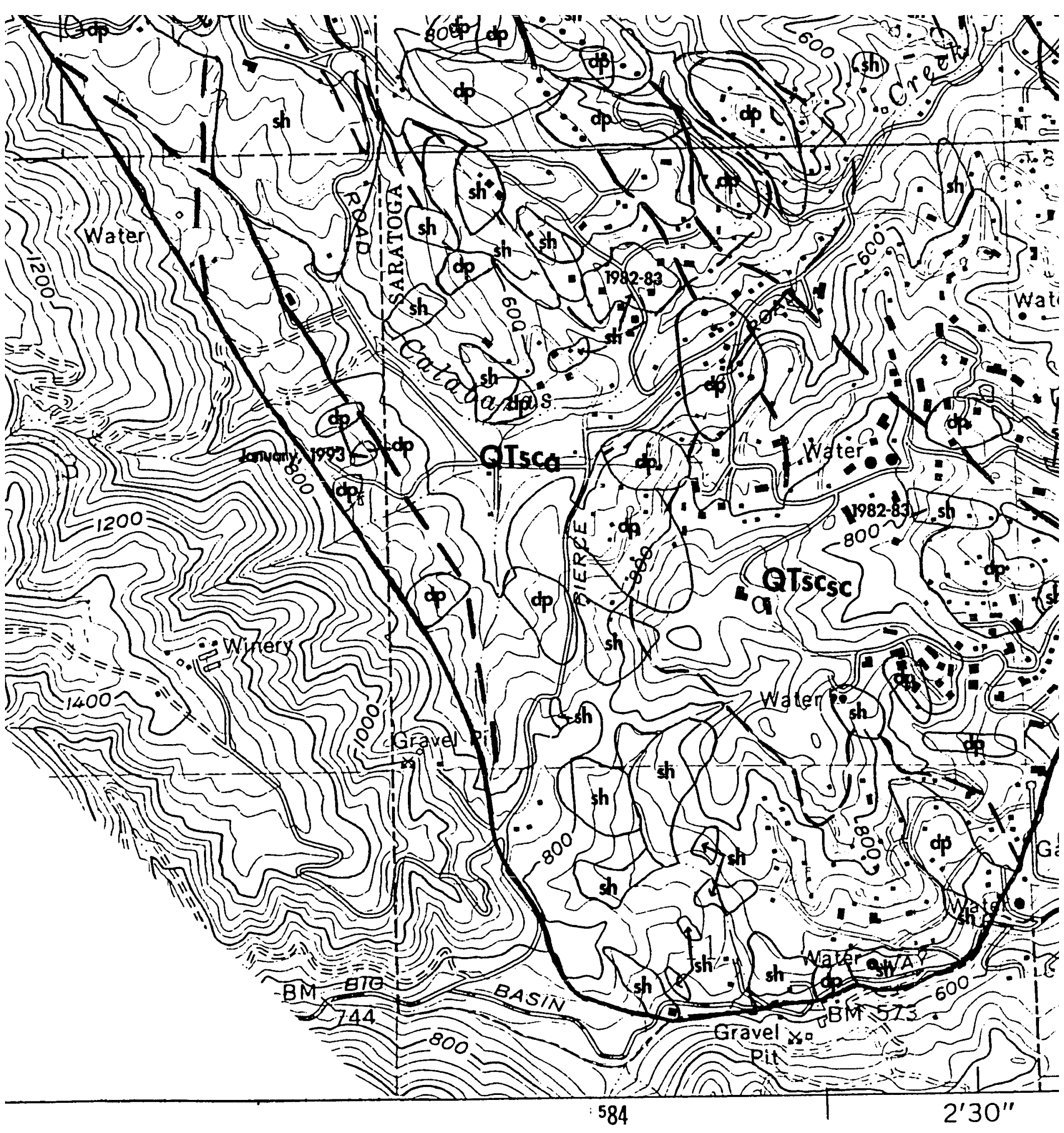

SCALE 1:12,000

0

1 MILE

\begin{tabular}{|c|c|c|c|c|c|c|}
\hline 000 & 2000 & 3000 & 4000 & 5000 & 6000 & 7000 \\
\hline$F$ & & $F$ & $\Rightarrow$ & $E$ & $d$ & $\vec{P}$ \\
\hline .5 & & 0 & & & & 15 \\
\hline
\end{tabular}




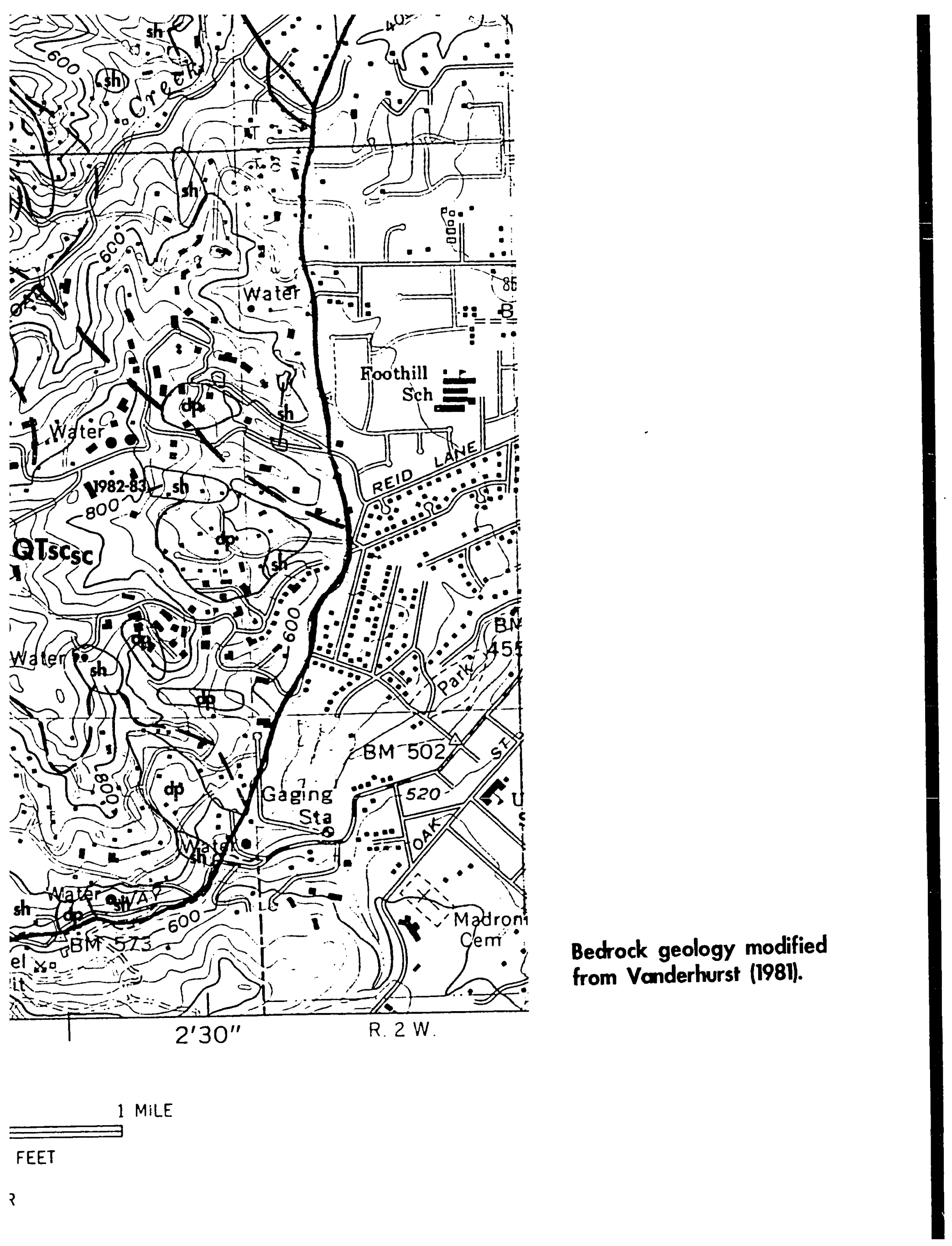




\section{PLEASE NOTE:}

Oversize maps and charts are filmed in sections in the following manner:

\section{LEFT TO RIGHT, TOP TO BOTTOM, WTTH SMALL OVERLAPS}

The following map or chart has been refilmed in its entirety at the end of this dissertation (not available on microfiche). A xerographic reproduction has been provided for paper copies and is inserted into the inside of the back cover.

Black and white photographic prints (17" $\times 23$ ") are available for an additional charge. 



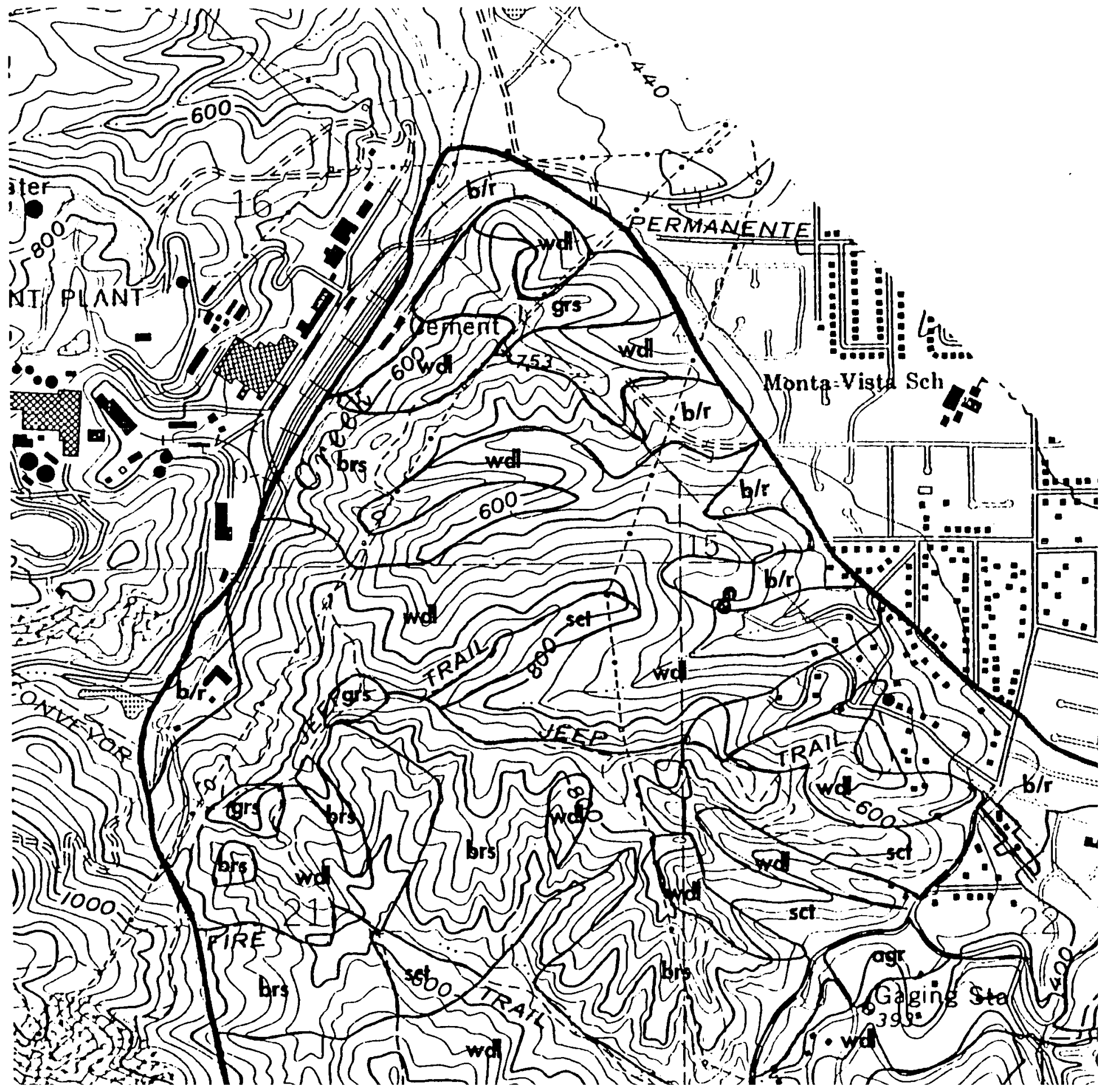




\section{GENERALIZED VEGETATION MAP}

\section{OF A PORTION OF THE}

\section{ERTINO 7.5' QUADRANGLE, CALIFORNIA}

(B. Reddig, 1994)

\section{EXPLANATIC \\ EXPLALAIIC}

b/r Bare/Resider
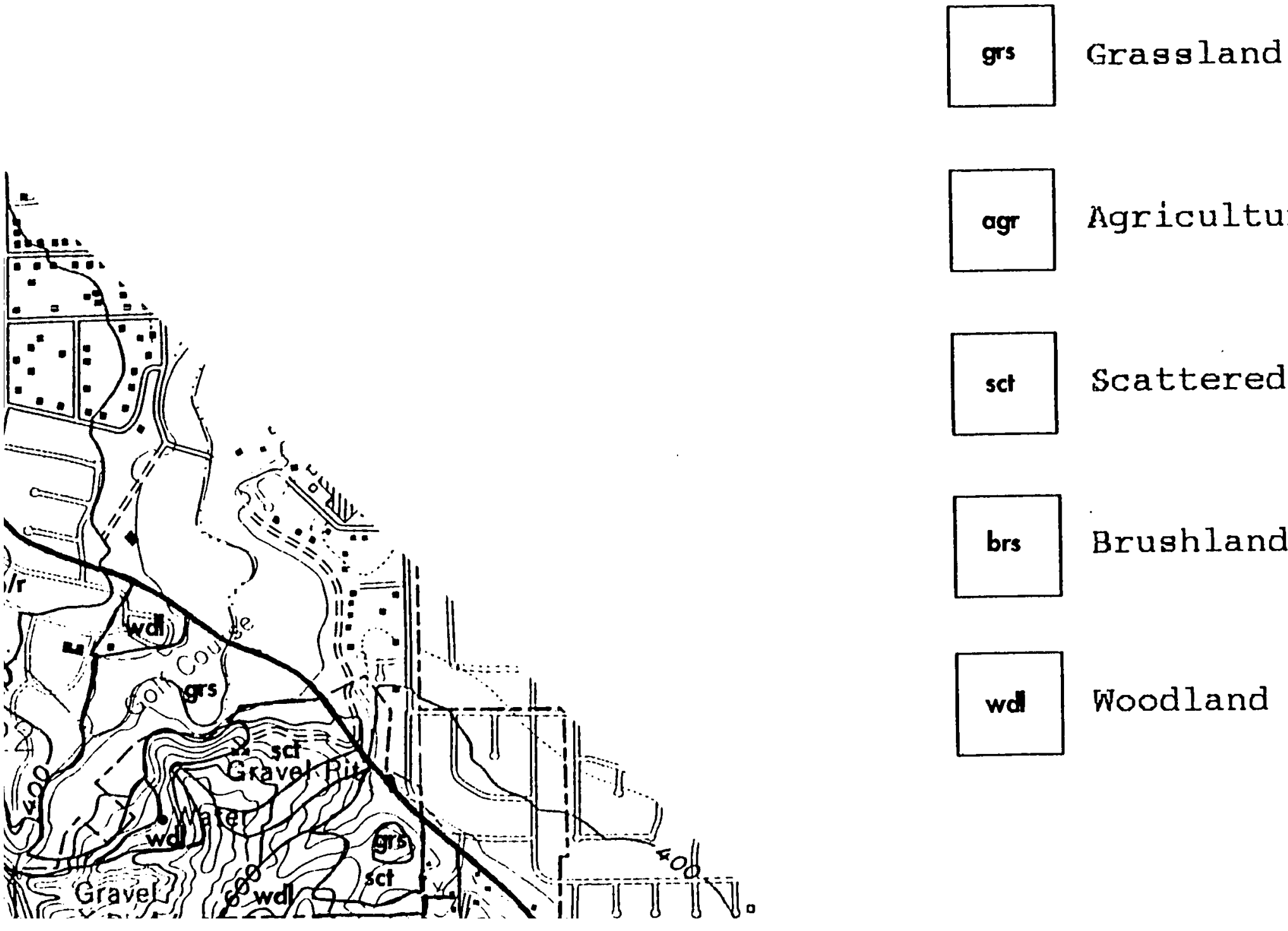

sct

brs

agr

Mgricultura]

griculteura

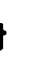

Scattered B1

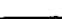

. 


\section{PLATE 2}

\section{EXPLANATION}

b/r Bare/Residential

grs Grassland

agr Agricultural

sct Scattered Brushland/Woodland

brs Brushland

wd Woodland 


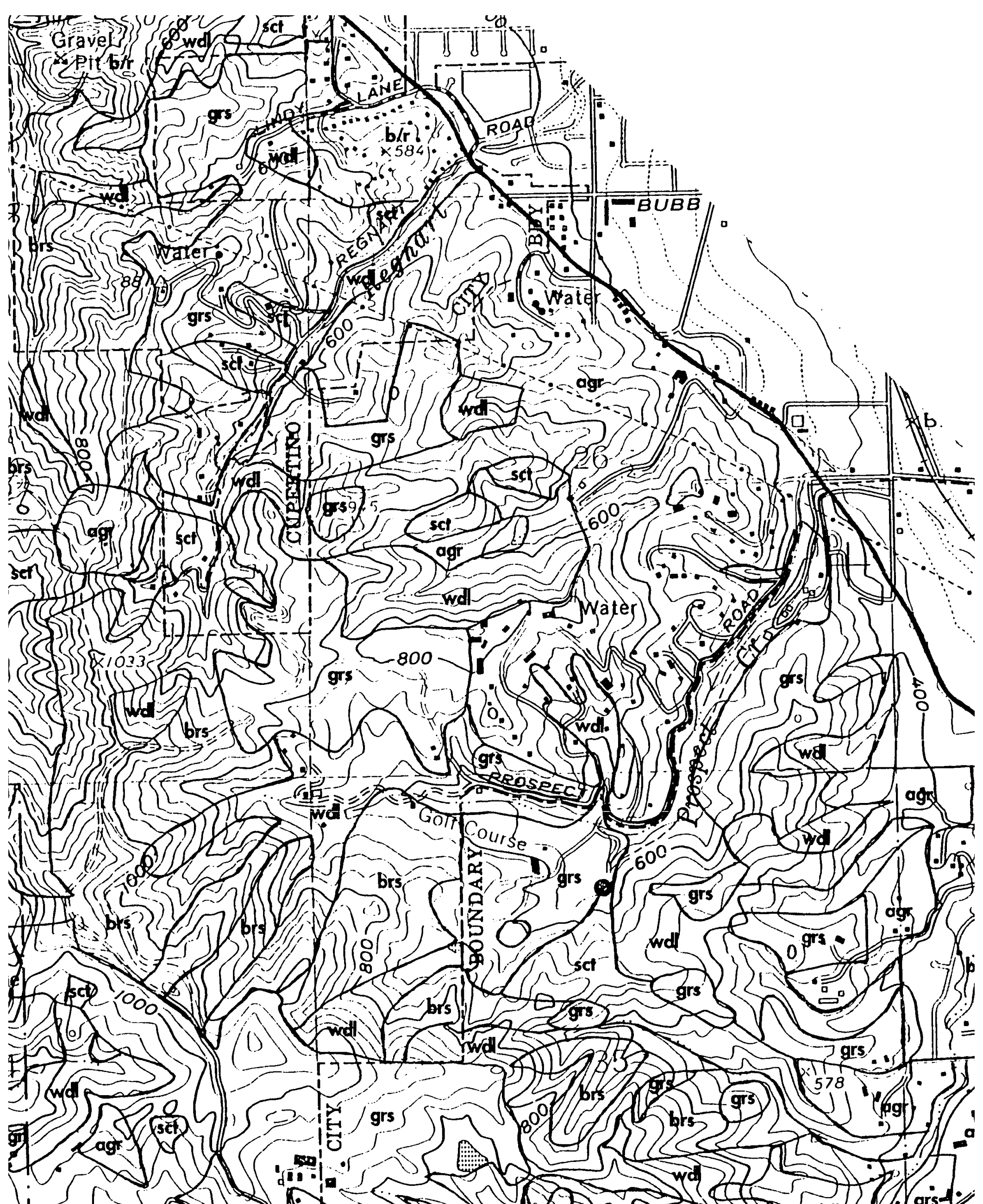





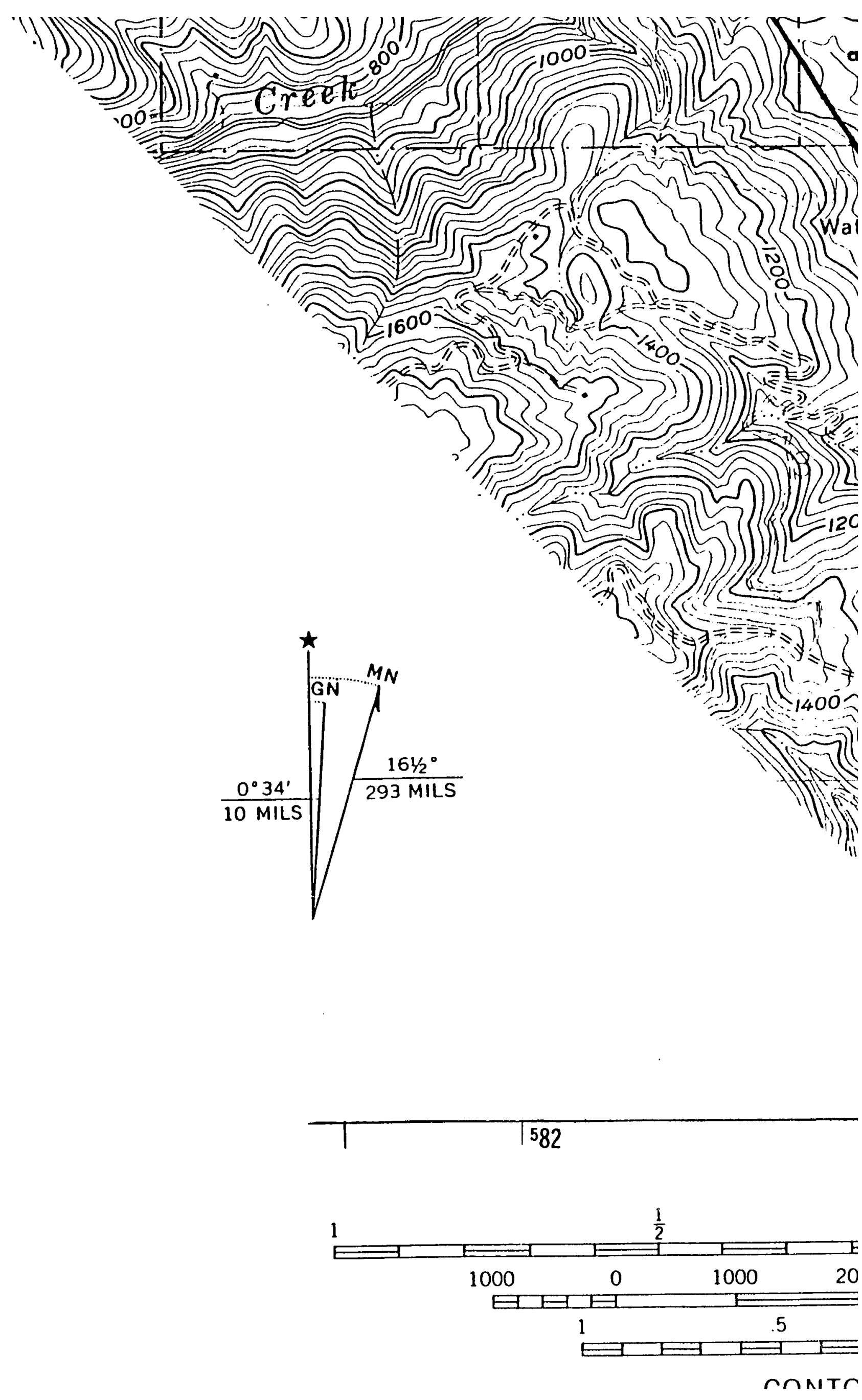




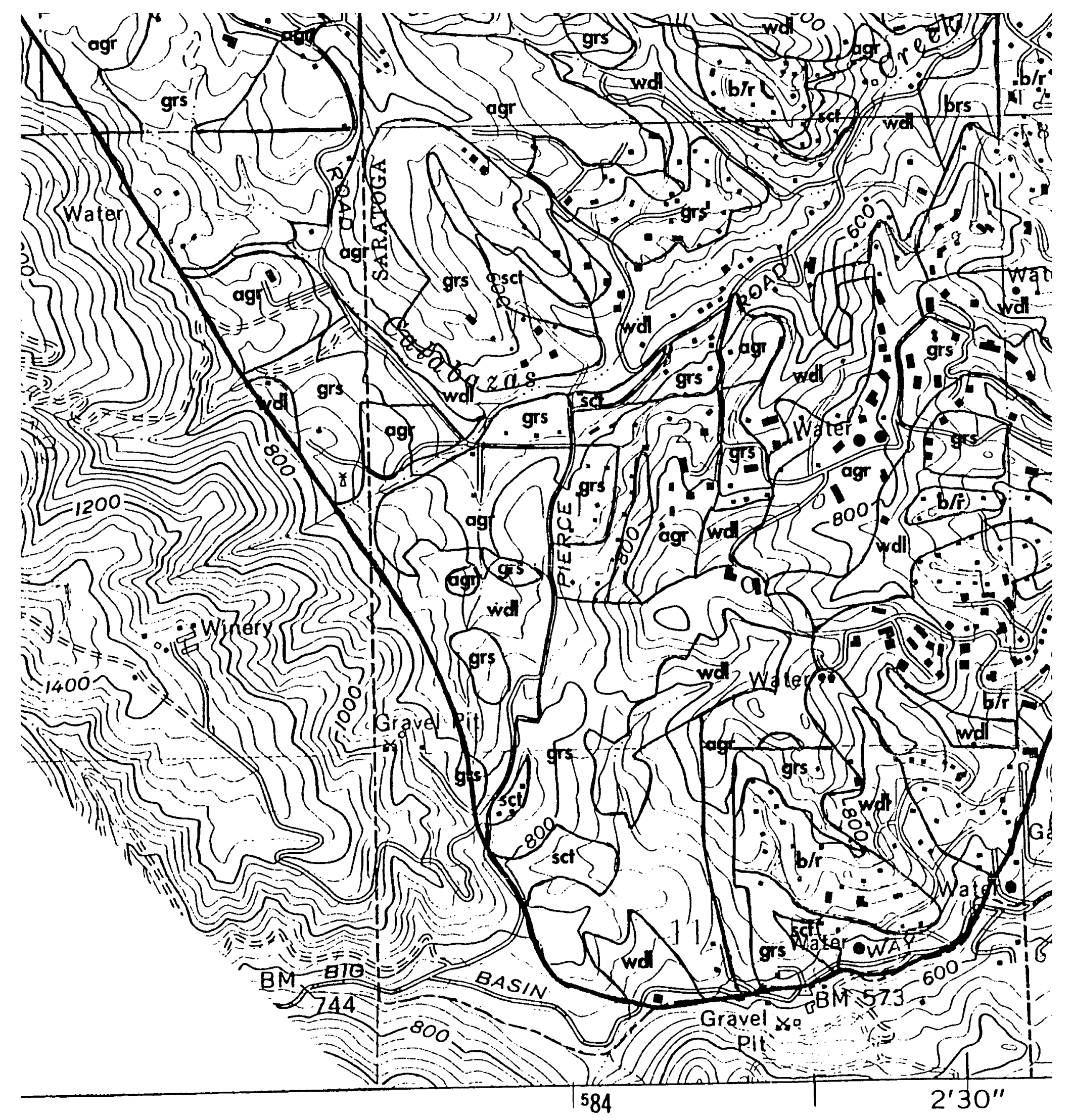

SCALE 1:12,000

0

1 MILE 

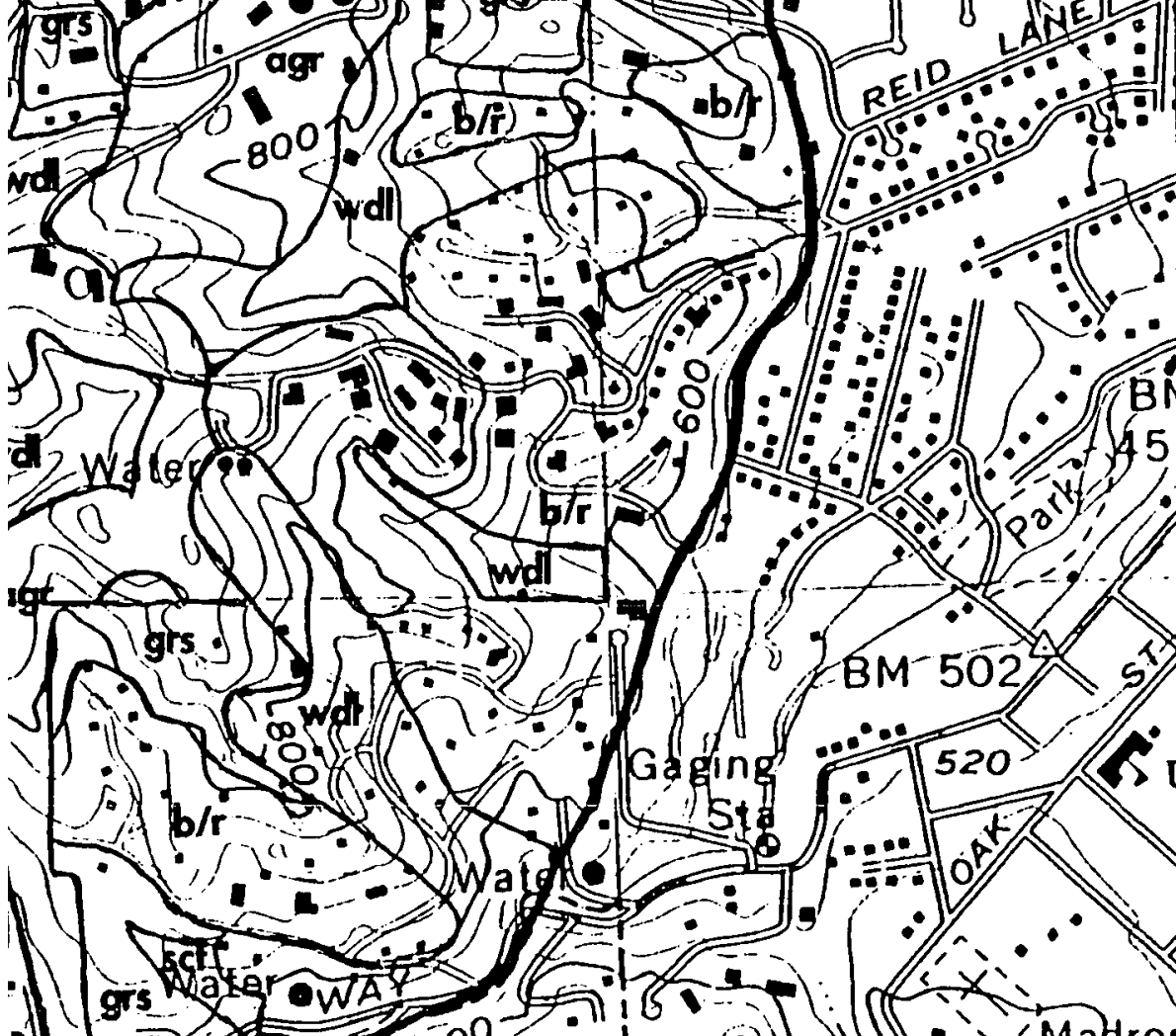

ira
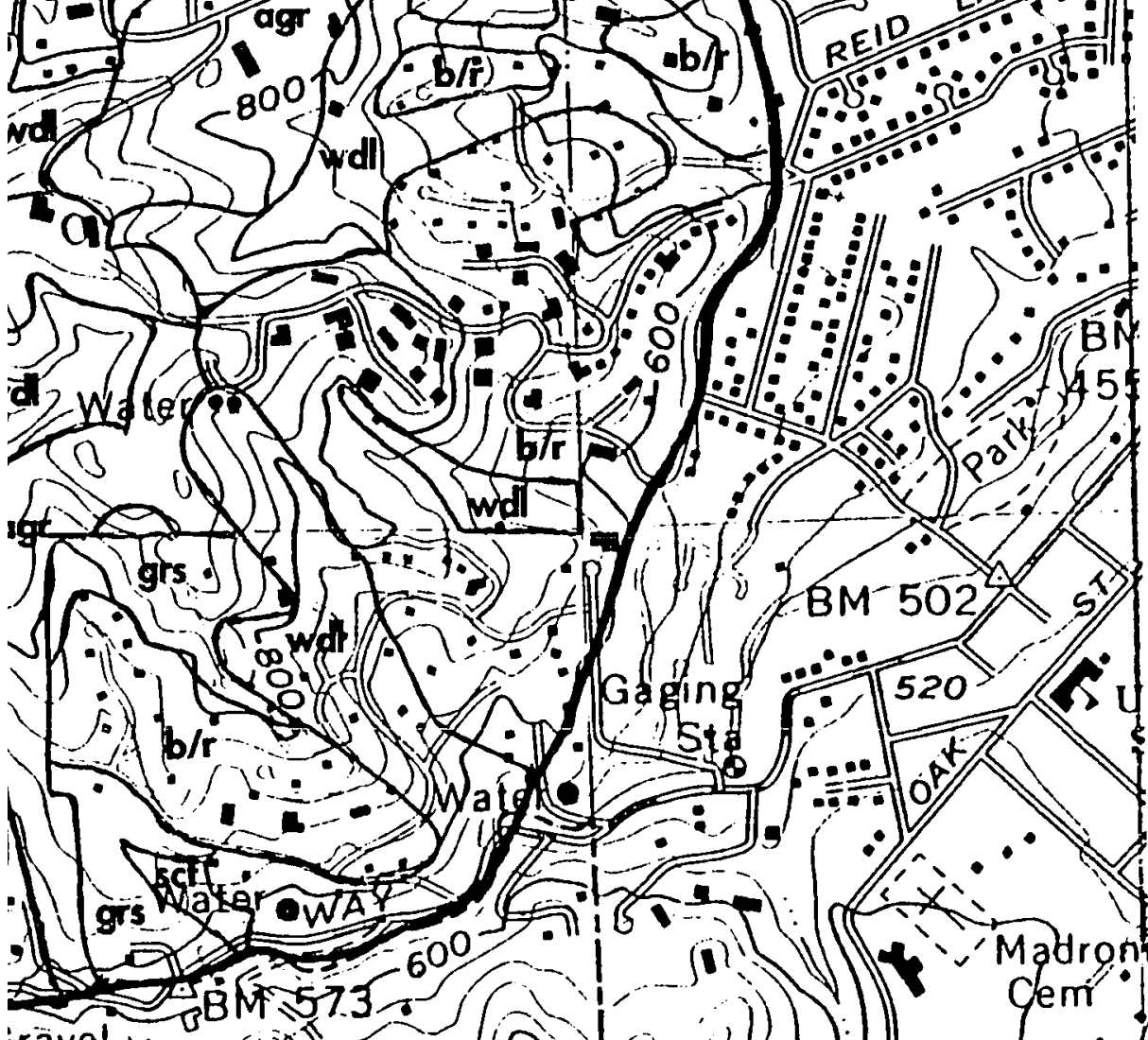

1 MILE 


\section{PLEASE NOTE:}

Oversize maps and charts are filmed in sections in the following manner:

\section{LEFT TO RIGHT, TOP TO BOTTOM, WITH SMALL OVERLAPS}

The following map or chart has been refilmed in its entirety at the end of this dissertation (not available on microfiche). A xerographic reproduction has been provided for paper copies and is inserted into the inside of the back cover.

Black and white photographic prints (17" $\times 23 ")$ are available for an additional charge. 



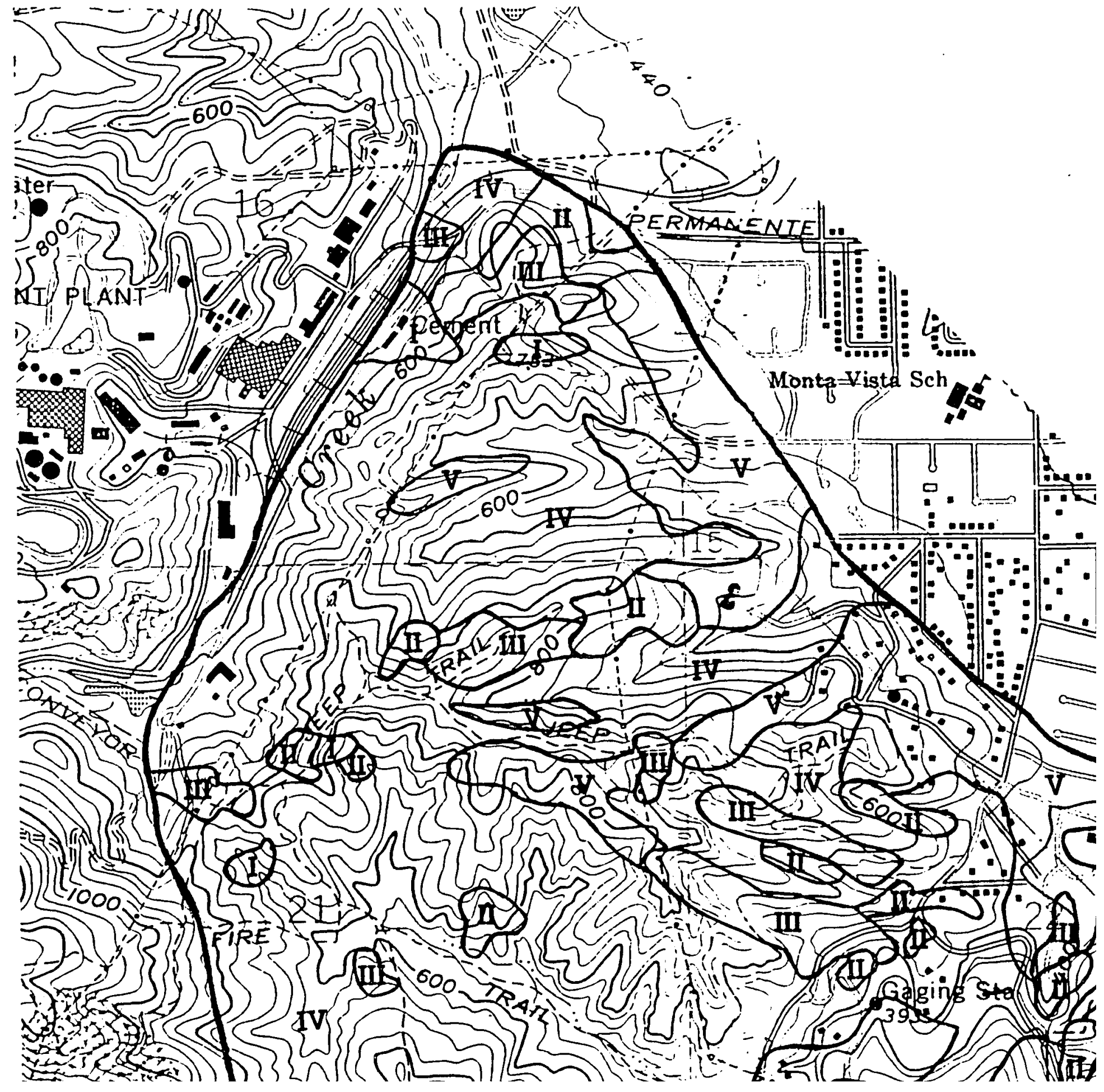




\section{LANDSLIDE POTENTIAL MAP}

\section{OF A PORTION OF THE}

\section{'ERTINO 7.5' QUADRANGLE, CALIFORNIA}

(B. Reddig, 1994)

EXPLANATI

I $>508$ Failu

II $308-508 \mathrm{Fa}$.

III $15 \%-30 \% \mathrm{Fa}$

IV $1 \%-15 \% \mathrm{Fai}$

v $<18$ Failur

Note: Failure Rates based a failure frequencies of geolos slope aspect, and vegełatio 


\section{PLATE 3}

\section{EXPLANATION}

I $>50 \%$ Failure Rate

II 30\%-50\% Failure Rate

III 158-30\% Failure Rate

IV 1\%-15\% Failure Rate

V $\quad<18$ Failure Rate

Note: Failure Rates based on the combined failure frequencies of geology, slope angle, dame menort and varnotertion. 
slope aspect, and vegetation.

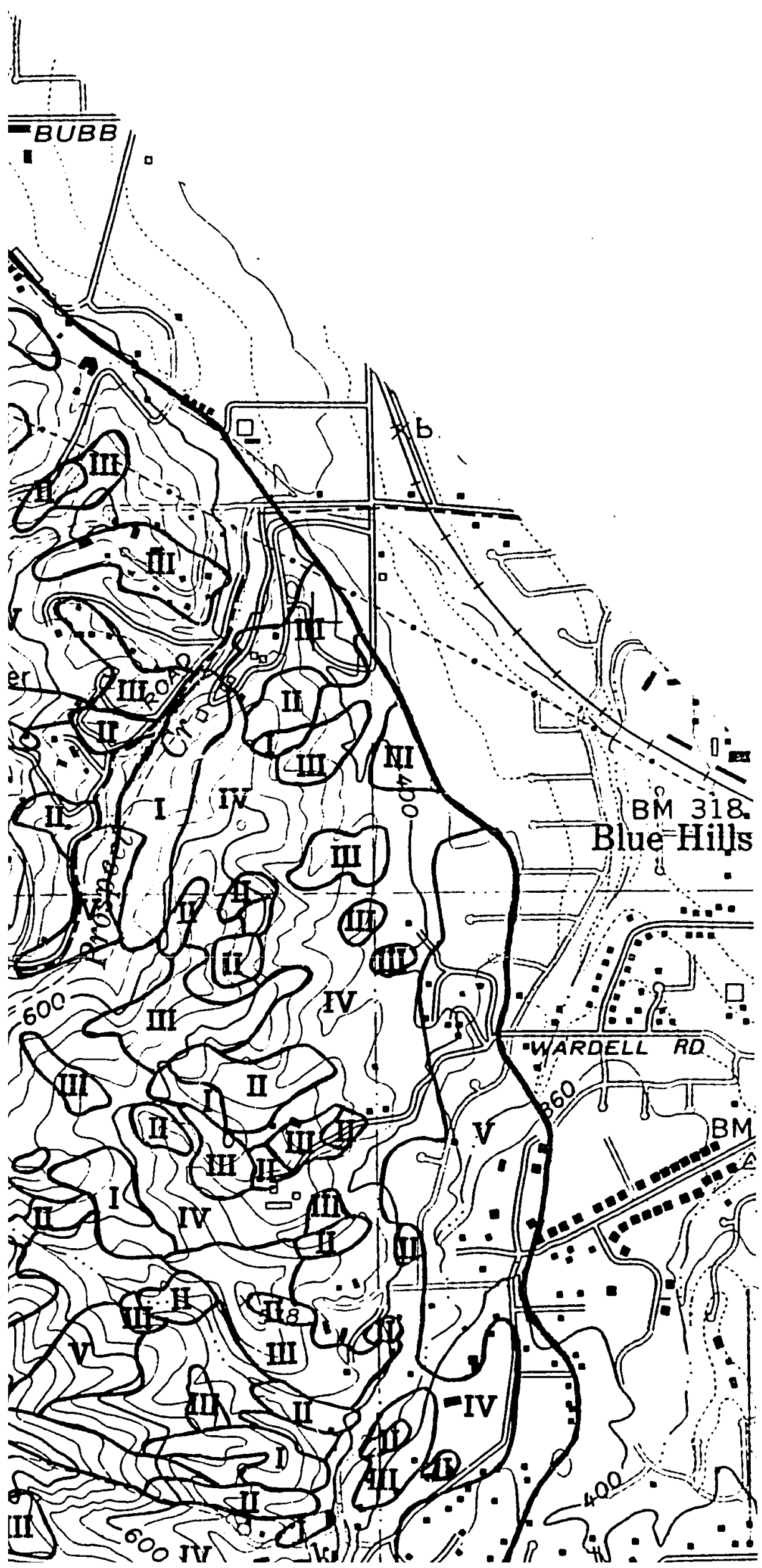



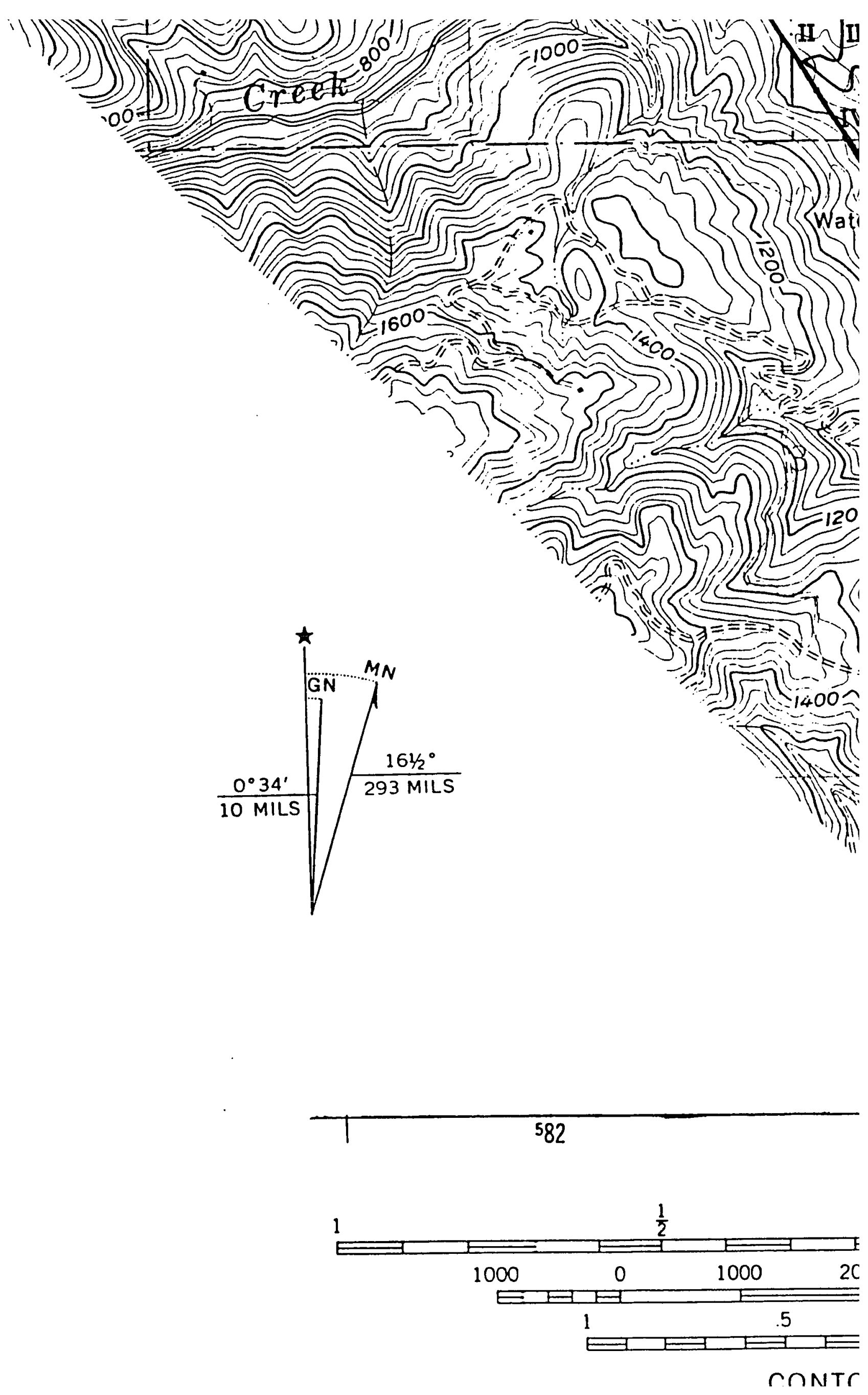


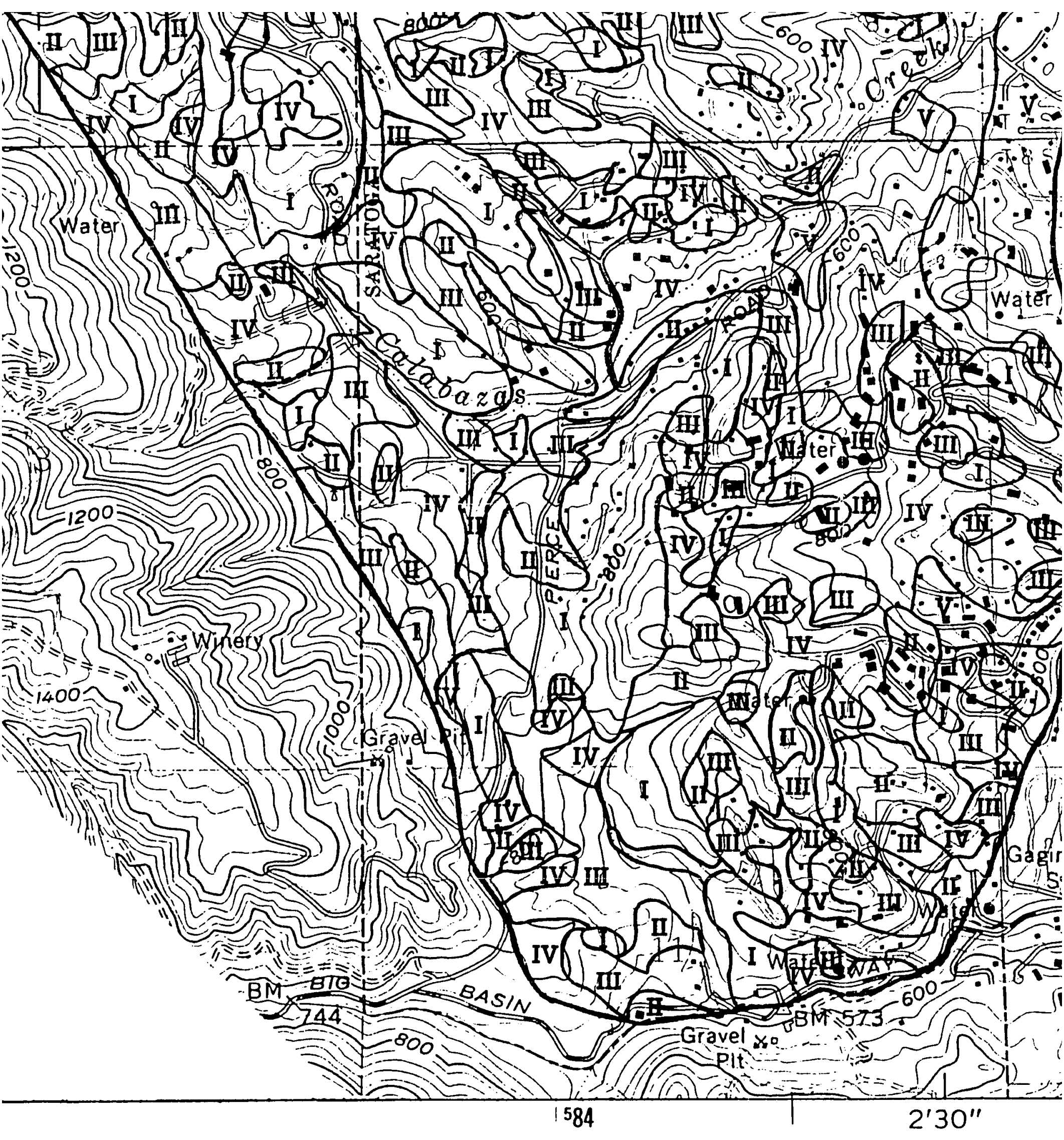

SCALE 1:12,000

0

1 MILE 


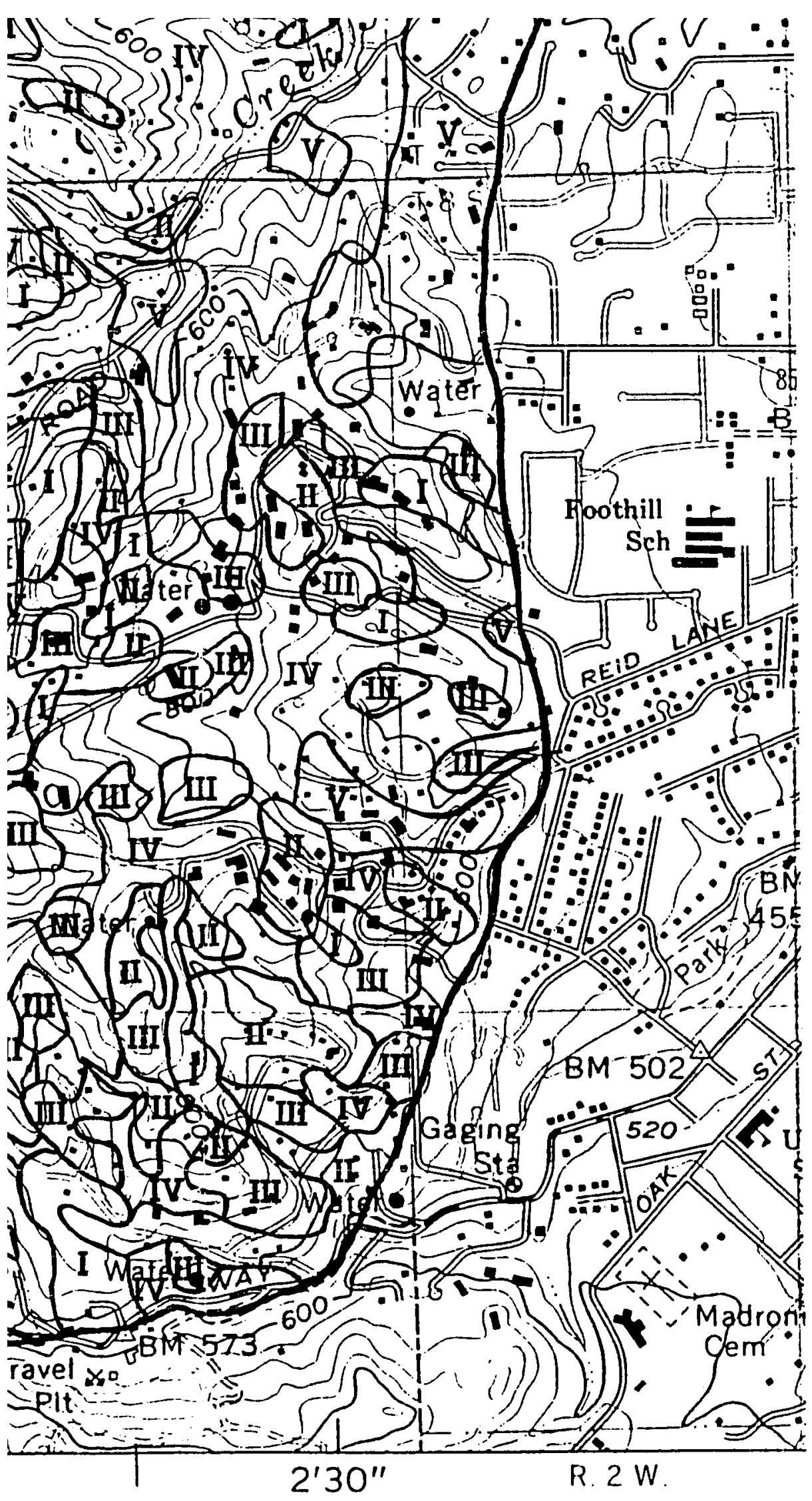

1 MILE

100 FEET 